Cover Photograph. View looking downstream at the Middle Fork Saline River between Danville Road and Goosepond Road bridges. Photograph by Aaron L. Pugh, U.S. Geological Survey. 


\section{Geomorphic Characterization of the Middle Fork Saline River: Garland, Perry, and Saline Counties, Arkansas}

By Aaron L. Pugh, Thomas J. Garday, and Ronald Redman

Prepared in cooperation with the Arkansas Natural Resources Commission and the U.S.

Department of Agriculture-Natural Resources Conservation Service-National Water Management Center

Scientific Investigations Report 2007-5152 


\section{U.S. Department of the Interior DIRK KEMPTHORNE, Secretary}

\section{U.S. Geological Survey \\ Mark D. Myers, Director}

\section{U.S. Geological Survey, Reston, Virginia: 2008}

For product and ordering information:

World Wide Web: http://www.usgs.gov/pubprod

Telephone: 1-888-ASK-USGS

For more information on the USGS--the Federal source for science about the Earth, its natural and living resources, natural hazards, and the environment:

World Wide Web: http://www.usgs.gov

Telephone: 1-888-ASK-USGS

Any use of trade, product, or firm names is for descriptive purposes only and does not imply endorsement by the U.S. Government.

Although this report is in the public domain, permission must be secured from the individual copyright owners to reproduce any copyrighted materials contained within this report.

Suggested citation:

Pugh, A.L., Garday, T.J., and Redman, Ronald., 2008, Geomorphic characterization of the Middle Fork Saline River: Garland, Perry, and Saline Counties, Arkansas: U.S. Geological Survey Scientific Investigations Report 2007-5152, $65 \mathrm{p}$. 


\section{Contents}

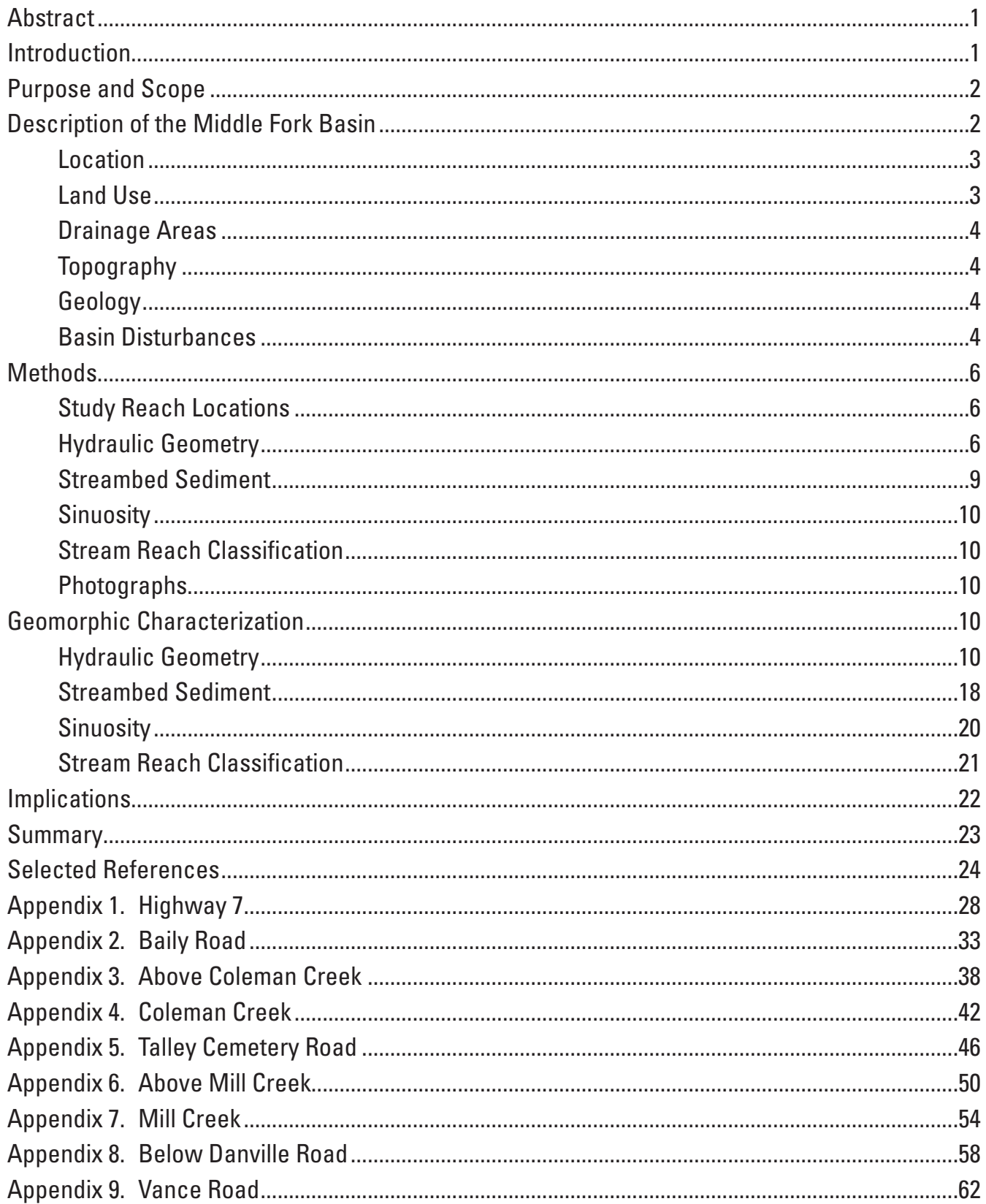

\section{Figures}

1. Map showing study reach locations along the Middle Fork Saline River............................2

2. Map showing physiography of Arkansas ......................................................................

3. Map showing geology of Middle Fork Saline River Basin ....................................................

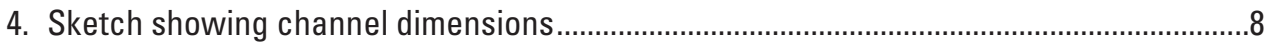

5. Sketch showing bankfull and flood-prone dimensions .....................................................

6. Diagram showing pebble axis..................................................................................... 
7-11. Graphs showing:

7. Preliminary bankfull channel dimensions as a function of drainage area for streams in the Ouachita Mountains of Arkansas and Oklahoma, with 95 percent prediction and confidence intervals.

8. Preliminary regional hydraulic geometry curves for the Ouachita Mountains of Arkansas and Oklahoma and reach data from the Middle Fork Saline River..................................13

9. Estimated changes in suspended sediment with changes in discharge for two U.S. Geological Survey stream gaging stations-Middle Fork Saline River below Jessieville and Middle Fork Saline River near Owensville.

10. Stream hydraulic geometry from U.S. Geological Survey discharge measurements.......17

11. Middle Fork Saline River streambed material analysis of particle size, tractive force, sorting, and location.

\section{Tables}

1. Geologic stratigraphic summary of the Middle Fork Basin ................................................

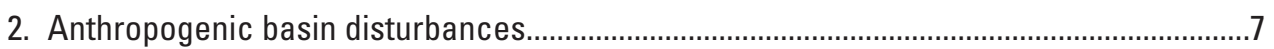

3. Summary of channel geometry characteristics .......................................................... 11

4. Comparison of Middle Fork bankfull hydraulic geometry with preliminary Ouachita Mountains regional hydraulic geometry.

5. Comparison of estimated changes in suspended sediment with changes in discharge at two U.S. Geological Survey stream gaging stations-Middle Fork Saline River below Jessieville (07362641) and Middle Fork Saline River near Owensville (07362693)

6. Comparison of Middle Fork hydraulic geometry dimensions from two U.S. Geological Survey stream gaging stations-Middle Fork Saline River below Jessieville (07362641) and Middle Fork Saline River near Owensville (07362693).

7. Middle Fork streambed material analysis of particle size, tractive force, sorting, and location.

8. Changes in sinuosity from 1992 to 2002. 


\section{Conversion Factors and Datums}

\begin{tabular}{|c|c|c|}
\hline Multiply & By & To obtain \\
\hline \multicolumn{3}{|c|}{ Length } \\
\hline inch (in.) & 2.54 & centimeter (cm) \\
\hline foot (ft) & 0.3048 & meter $(\mathrm{m})$ \\
\hline mile (mi) & 1.609 & kilometer (km) \\
\hline \multicolumn{3}{|c|}{ Slope } \\
\hline foot per mile (ft/mi) & 0.0001893 & meters per meter $(\mathrm{m} / \mathrm{m})$ \\
\hline \multicolumn{3}{|c|}{ Area } \\
\hline square foot $\left(\mathrm{ft}^{2}\right)$ & 0.09290 & square meter $\left(\mathrm{m}^{2}\right)$ \\
\hline square mile $\left(\mathrm{mi}^{2}\right)$ & 2.590 & square kilometer $\left(\mathrm{km}^{2}\right)$ \\
\hline \multicolumn{3}{|c|}{ Flow rate } \\
\hline foot per second (ft/s) & 0.3048 & meter per second (m/s) \\
\hline cubic foot per second $\left(\mathrm{ft}^{3} / \mathrm{s}\right)$ & 0.02932 & cubic meter per second $\left(\mathrm{m}^{3} / \mathrm{s}\right)$ \\
\hline \multicolumn{3}{|c|}{ Mass } \\
\hline ton per day (ton/d) & 0.9072 & megagram per day $(\mathrm{Mg} / \mathrm{d})$ \\
\hline \multicolumn{3}{|c|}{ Stress } \\
\hline pound force per square foot (lbf/ $\left./ \mathrm{ft}^{2}\right)$ & 4.88243 & kilogram force per square meter $\left(\mathrm{kgf} / \mathrm{m}^{2}\right)$ \\
\hline \multicolumn{3}{|c|}{ Specific Weight } \\
\hline pound per cubic foot $\left(\mathrm{lb} / \mathrm{ft}^{3}\right)$ & 157.10919 & newton per cubic meter $\left(\mathrm{N} / \mathrm{m}^{3}\right)$ \\
\hline
\end{tabular}

Altitude, as used in this report, refers to distance above the vertical datum, and is referenced to the National Geodetic Vertical Datum of 1929 (NGVD of 1929).

Latitude and longitude are referenced to the North American Datum of 1983 (NAD of 1983). 


\title{
Geomorphic Characterization of the Middle Fork Saline River: Garland, Perry, and Saline Counties, Arkansas
}

\author{
By Aaron L. Pugh', Thomas J. Garday², and Ronald Redman ${ }^{3}$
}

\section{Abstract}

This report was prepared to help address concerns raised by local residents, State, and Federal agencies about the current geomorphic conditions of the Middle Fork Saline River. Over the past 30 years the Middle Fork Saline River Basin has experienced a marked increase in urbanization. The report summarizes the Middle Fork's current (2003) channel characteristics at nine stream reaches in the upper 91 square miles of the basin. Assessments at each study reach included comparing measured stream geometry dimensions (cross-sectional area, top width, and mean depth) at bankfull stage to regional hydraulic geometry curves for the Ouachita Mountains Physiographic Province of Arkansas and Oklahoma, evaluations of streambed materials and sinuosity, and classification of individual stream reach types.

When compared to the Ouachita Mountains' regional hydraulic geometry curves for natural, stable, stream reaches, five of the nine study reaches had slightly smaller crosssectional areas, longer top widths, and shallower depths. Streambed material analysis indicates that the Middle Fork is a bedrock influenced, gravel dominated stream with lesser amounts of sand and cobbles. Slight increases in sinuosity from 1992 to 2002 at seven of the nine study reaches indicate a slight decrease in stream channel slope. Analyses of the Middle Fork's hydraulic geometry and sinuosity indicate that the Middle Fork is currently overly wide and shallow, but is slowly adjusting towards a deeper, narrower hydraulic geometry.

Using the Rosgen system of channel classification, the two upstream study reaches classified as B $4 \mathrm{c}_{/ 1}$ stream types; which were moderately entrenched, riffle dominated channels, with infrequently spaced pools. The downstream seven study reaches classified as $\mathrm{C}_{/ 1}$ stream types; which were slightly entrenched, meandering, gravel-dominated, riffle/ pool channels with well developed flood plains. Analyses of stream reach types suggest that the downstream reaches of the Middle Fork are more vulnerable to streambank failure than the upstream reaches of the stream.

\section{Introduction}

Streams and their flood plains are complex natural systems. The combined effects of climate, geology, topography, and biology control the stability and sensitivity of fluvial landforms. Understanding how observed stream forms have developed helps in forecasting effects of different actions on future stream forms. Streams allowed to adjust their boundaries naturally will develop hydraulic geometry and slope in proportion to the incoming water and sediment discharge. Because natural streams are self-formed and self-maintained, it is important to relate measurable features identifiable in the field with consistency so comparisons may be made. The bankfull or effective discharge of alluvial rivers in humid regions is generally a flood of moderate magnitude with a recurrence interval of 1 to 2 years (Annable, 1994). Bankfull stage indicators and their associated discharge serve as consistent morphological indices, which can be related to the formation, maintenance, and channel dimensions that exist under the current hydrologic and sediment conditions.

The U.S. Geological Survey (USGS) in cooperation with the Arkansas Natural Resources Commission (ANRC) and the U.S. Department of Agriculture-Natural Resources Conservation Service-National Water Management Center (USDA-NRCS-NWMC) participated in a study to characterize the geomorphology of the Middle Fork Saline River to help address concerns raised by local residents and State and Federal agencies. Two of the concerns raised were a changing hydrologic regime because of urban development and water withdrawals, and non-point pollution resulting from a broad assortment of activities. Personnel from the three agencies conducted fieldwork on the Middle Fork Saline River from March through October 2003. This study is one of several studies of the Middle Fork currently (approximately 2003 through 2007) being conducted by various entities. The other studies may yield results that could help place the results described in this report in a broader context.

\footnotetext{
${ }^{1}$ U.S. Geological Survey

${ }^{2}$ Natural Resources Conservation Service

${ }^{3}$ Arkansas Natural Resources Commission
} 


\section{Purpose and Scope}

The purpose of this report is to summarize the Middle Fork Saline River's (known locally and hereafter referred to as the Middle Fork) current (2003) channel geomorphic characteristics. Channel geomorphic characteristics examined include hydraulic stream geometry dimensions (cross-sectional area, top width, and mean depth), sinuosity, stream reach classification, channel bed material, bankfull stage tractive stresses, and basin disturbances. Portions of this report are applicable to other streams within the Ouachita Mountains Physiographic Province, but such applications should be made cautiously because of the unique anthropogenic activities that have taken place in the Middle Fork's Basin over the past 25 years.

This report focuses on the upper $91 \mathrm{mi}^{2}$ of the basin upstream from Vance Road (fig. 1). Stream channel geometry dimensions and bed-material samples were collected at seven reach locations along the Middle Fork and at two reach locations along tributaries to the Middle Fork. Starting at the upstream end of the basin and traveling downstream, the nine study reach locations were: (1) Highway 7, (2) Baily Road, (3) Above Coleman Creek, (4) Coleman Creek, (5) Talley Cemetery Road, (6) Above Mill Creek, (7) Mill Creek, (8) Below Danville Road, and (9) Vance Road (fig. 1).
Streams have inherent dynamic qualities by which change continually occurs in the stream position and shape. Changes may be slow or rapid, but all streams are subjected to forces that cause changes to occur. The degree of stream channel change varies with hydrologic events, bed and bank material, type and extent of vegetation on the banks, and flood-plain use. A stable stream channel is one that over time, maintains its width, depth, and slope (sinuosity) while transporting the water and sediments produced within the basin without excessive erosion or deposition. Data collected for this report represents a snapshot in time; accordingly stream stability can only be partially assessed, limited to the variables examined. Consequently, for this report, stream stability refers to a direct comparison between the stream's bankfull hydraulic geometry and the hydraulic geometry of a "regional stream" with the same drainage area. Agreement of bankfull geometry indicates stability, whereas, departure indicates increased or decreased sediment transport capacity, stream slope, or stream water discharge.

\section{Description of the Middle Fork Basin}

To characterize a stream basin, it is essential to understand how the local landscape has evolved over time- both

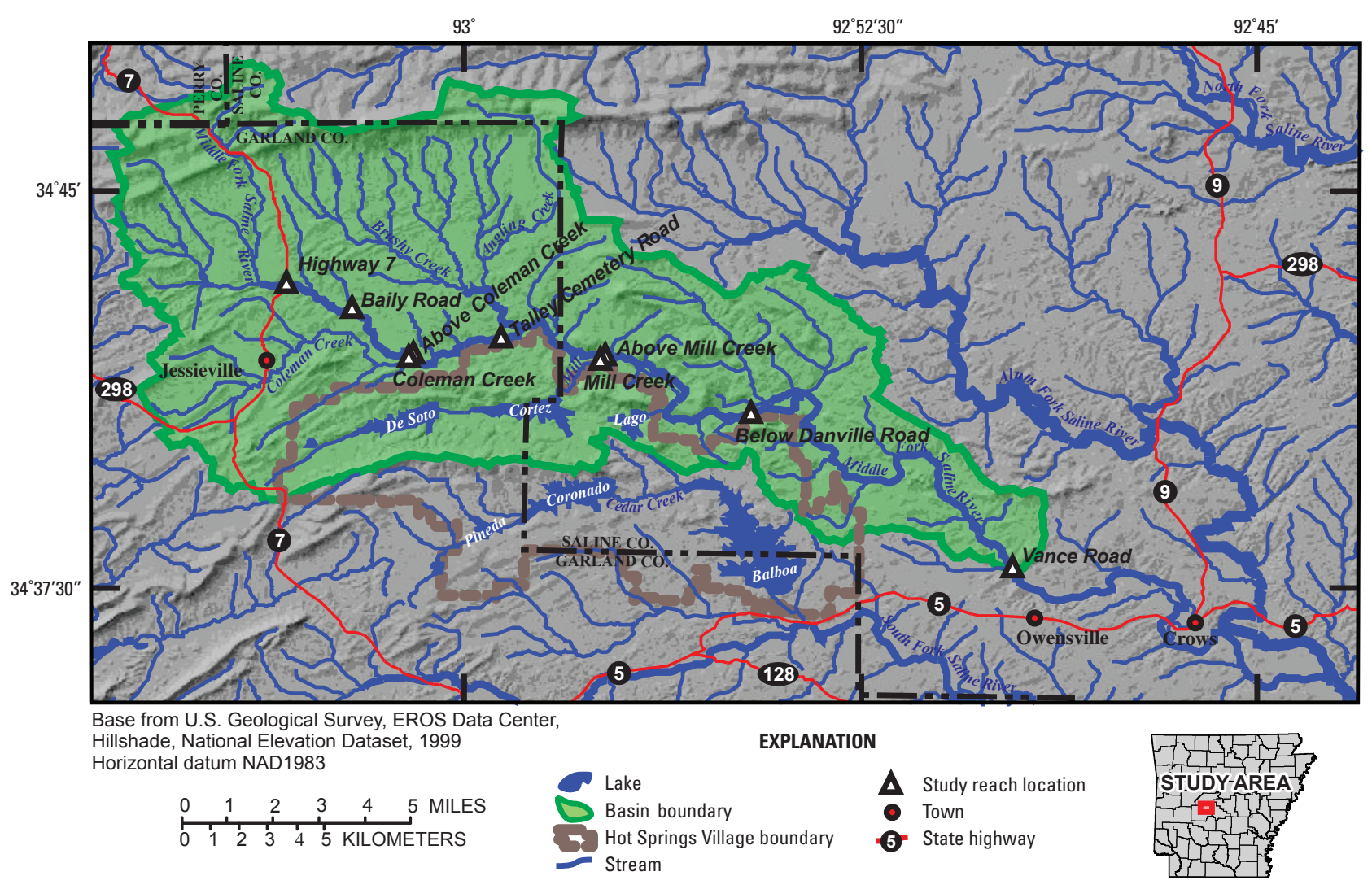

Figure 1. Study reach locations along the Middle Fork Saline River. 
at a human time scale and a geologic time scale. This section contains descriptions of the Middle Fork's location, land use, drainage areas, topography, and geology.

\section{Location}

The Middle Fork is a part of the Saline River Basin, which in turn is part of the Ouachita River Basin. Geographically, the Middle Fork flows from the northwest to the southeast with its headwaters gathering in eastern Perry County, flowing across northeastern Garland County, and joining with the Alum Fork of the Saline River at their confluence near Crows, in western Saline County, Arkansas (fig. 1). The Middle Fork lies along the eastern flank of the Ouachita Mountains Physiographic Section, of the Interior Highlands Major Physiographic Division (fig. 2) (Fenneman, 1938).

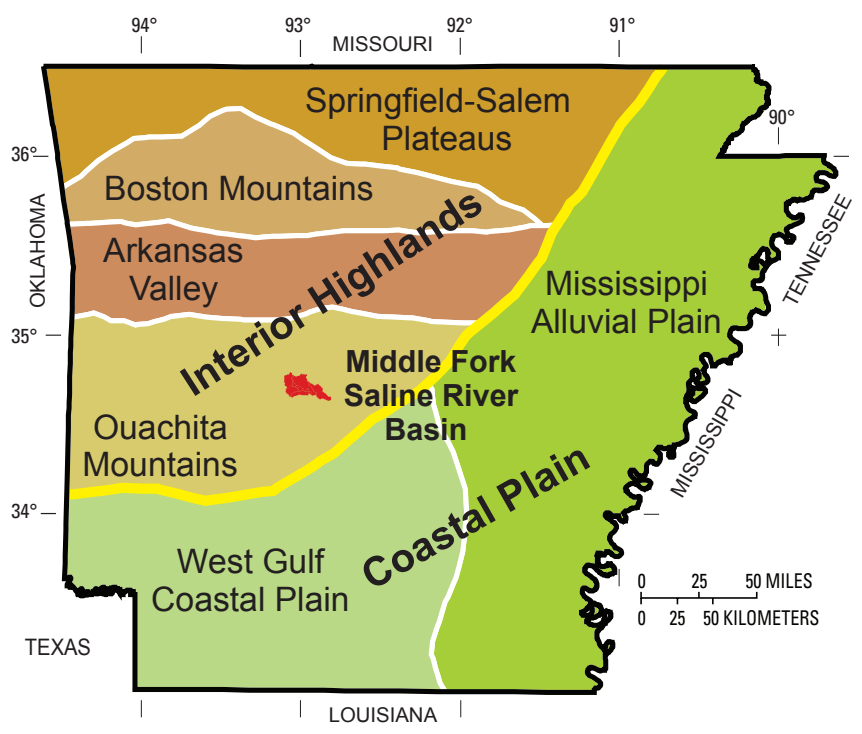

Figure 2. Physiography of Arkansas.

\section{Land Use}

From the nomadic hunters at the end of the last Ice Age, 12,000 to 15,000 Y.B.P. (years before the present date), to the homesteaders of the early 20th century, to the present, humans have inhabited the Ouachita Mountains. Because little historical land-use data exists, historical land use was inferred from archeological and historical census data. Examination of these data indicates that three distinct human activities have occurred in the Ouachita Mountains that may have affected stream basins. These activities were human habitation and associated infrastructure, the introduction of agriculture, and large scale timber harvesting.

The earliest known inhabitants of the Ouachita Mountains were the Paleo-Indians who occupied the region begin- ning about 11,500 Y.B.P. Archeological evidence suggests that the Paleo-Indians were highly mobile hunters and gatherers that would have minimally impacted Ouachita stream basins (Etchieson and others, 1999).

Approximately 2,000 Y.B.P., the population of the Ouachita Mountains increased as people began establishing more permanent settlements in the larger valleys. Maize (corn) was introduced to this area about 1,200 Y.B.P. and by the late 16th century, the Quapaw Indians occupied much of the region cultivating crops and raising livestock (Etchieson and others, 1999). Both permanent settlement and agricultural development would have affected the stream basins in which they occurred.

European settlers were slow to move into the Ouachita region until the interstate railroad system reached the region in the 1880's. The arrival of the railroad spurred a region-wide lumbering boom. Land acquisition records indicate that many of the rough upland areas were settled between the 1880's and the 1930's. Ultimately, low agricultural potential, overgrazing, over farming on highly erodable soils, and distance from markets resulted in widespread deprivation. Many of the upland farms were abandoned during the economic depression of the 1930's (Etchieson and others, 1999). The timber harvest and farming practices during this period could have drastically affected the stream basins in which they occurred.

The majority of land use within the Ouachita region, from the late 1930's through the present, has been forestry. Properties abandoned during the 1930's were typically purchased by timber companies or the U.S. Department of Agriculture (USDA) Forest Service (U.S. Department of Agriculture, Forest Service, no date). The effects of land use on stream basins during this period have varied depending on the management practices employed by the various timber companies and the USDA Forest Service.

Over the past 25 years, the Middle Fork Basin has experienced a rapid population growth. Census records indicate that the population of Saline and Garland Counties grew at a rate of approximately 15 percent for each decade from 1930 to 1970 . The exception to this growth was in Garland County, between 1950 and 1960, when the population decreased by 0.9 percent. Between 1970 and 1996, the area's population has increased 37 percent (University of Virginia, 1998). The greatest development has taken place in Hot Springs Village along the southern border of the basin. Construction at Hot Springs Village began in 1970 on 26,000 acres, of which approximately half is within the Middle Fork Basin. In 2003, there were 13,000 residents and 32,000 home sites in the Village. The development of Hot Springs Village includes the construction of numerous dams on Middle Fork tributaries including Lake DeSoto (200 acres) and Lake Cortez (245 acres) in the Mill Creek Basin and Lake Lago (100 acres) on an unnamed tributary to the Middle Fork (Hot Springs Village Property Owner's Association, 2003). This residential construction and associated infrastructure has affected the Middle Fork Basin and is, in part, the reason for this study. 


\section{Drainage Areas}

At its confluence with the Alum Fork, the Middle Fork drains an area of approximately $107 \mathrm{mi}^{2}$. This report only examines the upper part of the Middle Fork upstream from Vance Road (drainage area $91 \mathrm{mi}^{2}$ ). Several small creeks contribute to the upper Middle Fork's drainage. These include Coleman Creek (drainage area $10.9 \mathrm{mi}^{2}$ ), Brushy Creek (drainage area: $19.0 \mathrm{mi}^{2}$ ) and its tributary Angling Creek (drainage area $7.2 \mathrm{mi}^{2}$ ), and Mill Creek (drainage area $10.0 \mathrm{mi}^{2}$ ) (Yanchosek and Hines, 1979).

Drainage areas were delineated using a geographic information system and digital raster graphic topographic maps to outline the polygon area contributing drainage to each study reach. The areas of these polygons are reported as the study reach drainage areas.

For the purposes of this report, drainage areas are divided into two categories, controlled and uncontrolled. Controlled drainage areas are associated with those basins that have some type of structural control (dams) or substantial amounts of impervious surfaces from urbanization. Dams tend to attenuate peak flows, store bed-load sediments, and increase base flows, while impervious surfaces from urban development increase runoff, which increases storm event peak flows and shortens storm event flow durations. Uncontrolled drainage areas are associated with basins that have no structural control and are free to flow in a natural manner, and storm event peak flows are minimally affected by land use (minimal impervious surfaces).

An example of uncontrolled and controlled drainage areas in the Middle Fork Basin is the Mill Creek Basin. Prior to the construction of Lakes DeSoto and Cortez, Mill Creek's uncontrolled drainage area equaled its total drainage area, $10 \mathrm{mi}^{2}$. Following the construction of these lakes, $9.1 \mathrm{mi}^{2}$ of Mill Creek's drainage area flows through the lakes, becoming controlled drainage area, and leaving an uncontrolled drainage area of $0.9 \mathrm{mi}^{2}$. Because Mill Creek contributes drainage area to the Middle Fork, any drainage areas measured below the confluence of these two streams also have uncontrolled drainage areas reduced by $9.1 \mathrm{mi}^{2}$. This includes the Below Danville Road and Vance Road study reaches whose uncontrolled drainage areas are reduced from $71.0 \mathrm{mi}^{2}$ to $61.9 \mathrm{mi}^{2}$ and $90.8 \mathrm{mi}^{2}$ to $81.7 \mathrm{mi}^{2}$, respectively.

\section{Topography}

The topography of the Middle Fork Basin is directly related to the local geology. Relief or difference in elevation between the ridgetops and valley bottoms for the Middle Fork Basin is the result of the compression and uplift of Paleozoic rocks and the subsequent erosion and entrenchment of drainage channels into the land surface. Elevations within the Middle Fork Basin range from 1,886 ft above National Geodetic Vertical Datum of 1929 (NGVD of 1929) at Smith Pinnacle located in the Jackfork Sandstone ridge bordering the northern edge of the basin to approximately $350 \mathrm{ft}$ at the Middle Fork's confluence with the Alum Fork underlain by Womble Shale. The maximum relief for the basin is 1,536 ft. The ridges and valleys trend generally in an east-west direction. Ridges consist of sandstone, quartzite, and to a lesser extent novaculite; while the larger valleys are underlain by shale (Arkansas Geological Commission, 2000a, 2000b). Smaller, upland valleys underlain by sandstone are $\mathrm{v}$-shaped, while the larger, lowland valleys underlain by shales are u-shaped.

\section{Geology}

All the geological formations within the Middle Fork Basin (table 1, fig. 3) are of sedimentary origin deposited as nearly flat layers of mud, sand, gravel, lime, and silica in the marine waters of an ancient deep basin that occupied the region. With the load and weight of the overlying sediments, they were subsequently converted to shale, sandstone, conglomerate, limestone, and chert. These consolidated deposits then were subjected to intense compressive forces in late Paleozoic time that transported them towards the north causing them to bend, fold, and in many places, rupture. Ultimately, the region was uplifted, forming an extensive mountain range. This deformation, called the Ouachita orogeny, metamorphosed portions of these consolidated deposits in places, changing some shale to slate, sandstone to quartzite, and chert to novaculite. The uplift produced prominent east-west folds and large thrust faults in the strata. Subsequent to the Ouachita orogeny, the region was eroded and dissected with minor arching and extensional faulting. During the Pleistocene and Quaternary (recent times), the older rocks in the area were further eroded. Terrace, alluvial, and colluvial deposits represent some of the most recent products of these climatically related cycles of erosion and deposition (Arkansas Geological Commission, 2000a; 2000b).

Nine geologic formations are delineated within the Middle Fork Basin and range in age from early Ordovician age (Mazarn Shale) to Pennsylvanian age (Jackfork Sandstone). The rocks consist primarily of shale, sandstone, chert, and novaculite and generally are steeply inclined, fractured, folded, and faulted. The erosional surface of these Paleozoic rocks dips to the southeast at an average rate of $80 \mathrm{ft} / \mathrm{mi}$ (Plebuch and Hines, 1967) (table 1, fig. 3).

\section{Basin Disturbances}

The Middle Fork Basin is a complex hydrologic system. The changes in this system are the result of physical, chemi$\mathrm{cal}$, and biological processes operating within the system and the natural and anthropogenic changes to these processes over time. A number of anthropogenic disturbances to the Middle Fork Basin are known. These consisted of chemical disturbances including agricultural applications of pesticides and nutrients and stormwater runoff; biological disturbances 
Table 1. Geologic stratigraphic summary of the Middle Fork Basin (modified from Arkansas Geological Commission, 2000a, 2000b).

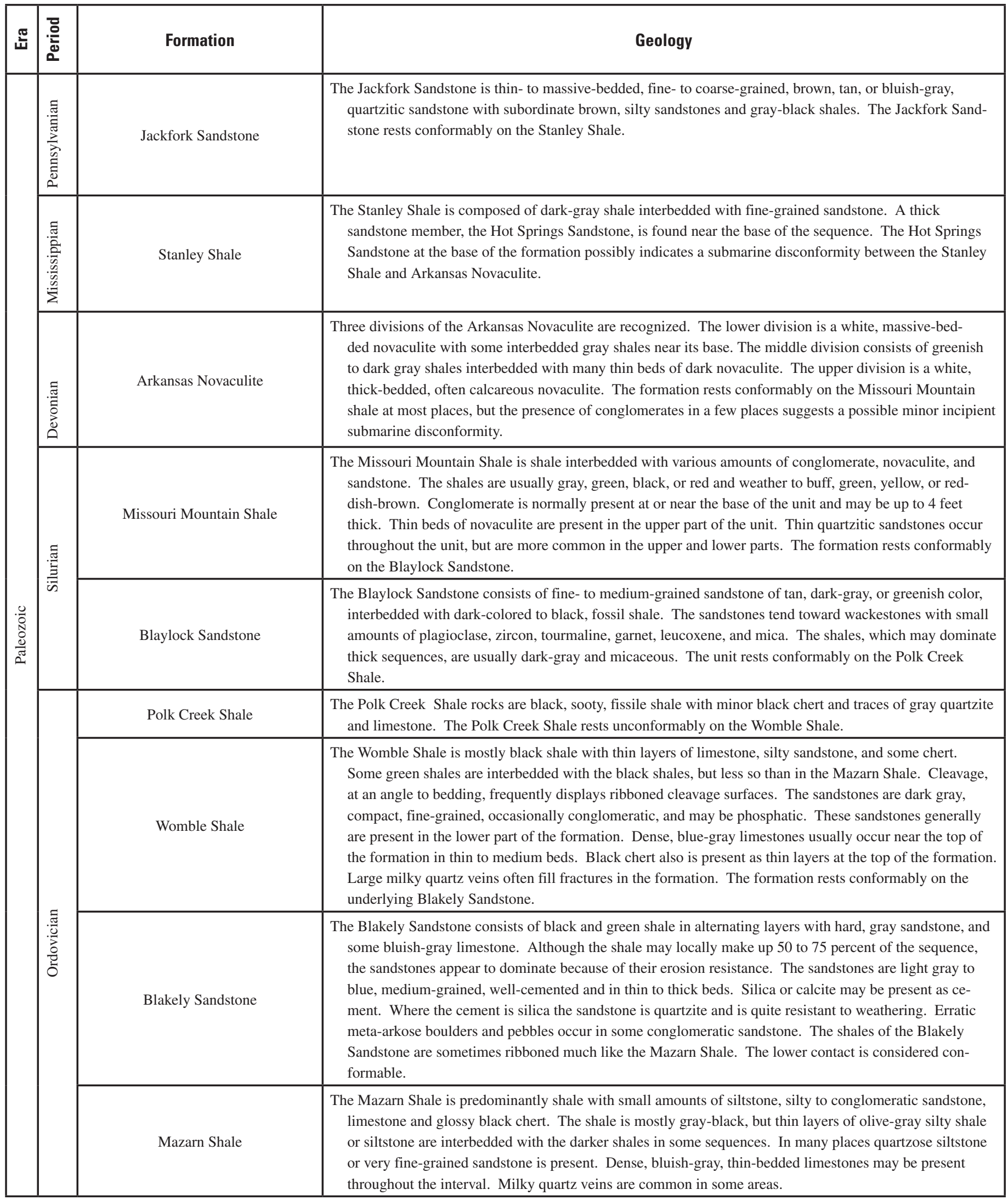




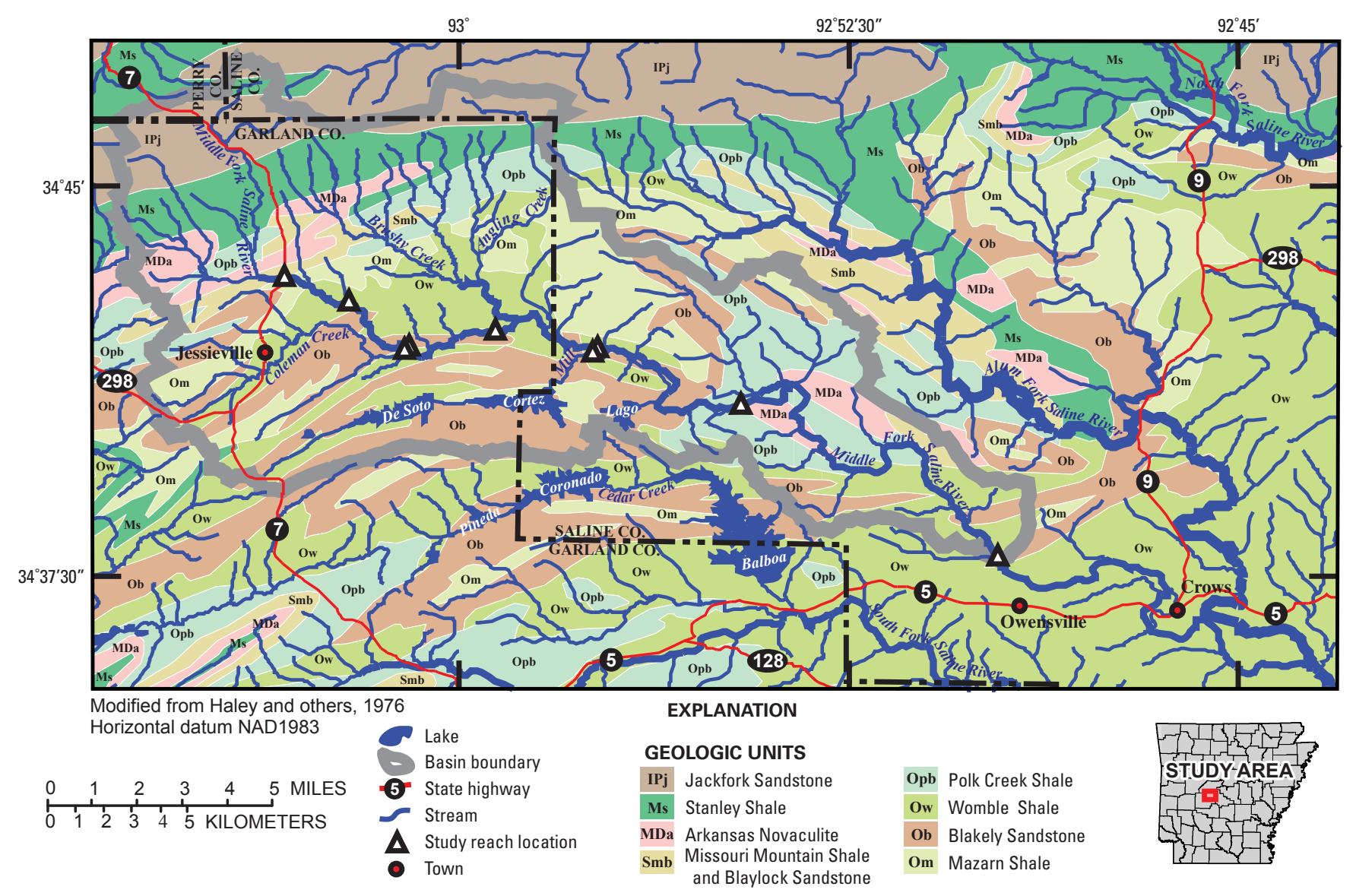

Figure 3. Geology of Middle Fork Saline River Basin.

including livestock grazing and the presence of exotic flora (kudzu); and physical disturbances including dams, weirs, utility crossings, bridges, gravel removal, water withdrawals, soil exposure and compaction (construction), and flood-plain reduction from urban or road encroachment. The known anthropogenic basin disturbances associated with each study reach are listed in table 2.

\section{Methods}

The following discussions describe the study reach locations and the methods used to sample at each location. Sampling included hydraulic geometry surveys including cross-sectional, profile, and bankfull indicator surveys, pebble counts, and digital photography.

\section{Study Reach Locations}

Nine study reach locations were selected following an initial reconnaissance of the Middle Fork Basin. Seven of these study reaches were located on the main stem of the Middle Fork. The remaining two study reaches were located on Coleman Creek and Mill Creek (tributaries to the Middle Fork). The initial reconnaissance of the basin was conducted to assess its general condition, locate study reaches, and to locate available benchmarks. The selected study reaches were generally upstream from and far enough away from bridges to minimize flow effects that bridges may have on the stream. Starting at the upstream end of the basin and traveling downstream, the nine study reaches were: (1) Highway 7, (2) Baily Road, (3) Above Coleman Creek, (4) Coleman Creek, (5) Talley Cemetery Road, (6) Above Mill Creek, (7) Mill Creek, (8) Below Danville Road, and (9) Vance Road (fig. 1).

\section{Hydraulic Geometry}

In natural stream environments, where the stream channel is connected to the flood plain and is allowed to adjust its width, depth, and sinuosity, bankfull discharges occur at stages where water completely fills the stream channel or is the maximum discharge that the channel can convey without flowing onto the flood plain. The flood plain is the flat area adjacent to the stream channel constructed by the present stream under the present climatic conditions and is frequently subject to flooding (Dunne and Leopold, 1978).

At each study reach, a total station survey instrument was used to obtain location and elevation data for bankfull indicators, riffle cross sections, and longitudinal profiles (thalweg 
Table 2. Anthropogenic basin disturbances.

\begin{tabular}{|c|c|c|c|c|c|c|c|c|c|c|}
\hline \multirow[b]{2}{*}{ Study reach } & \multicolumn{2}{|c|}{ Chemical } & \multicolumn{2}{|c|}{ Biological } & \multicolumn{6}{|c|}{ Physical } \\
\hline & 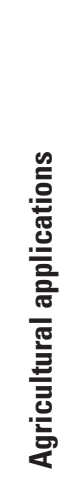 & 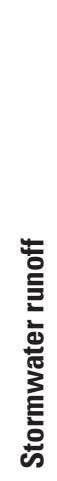 & 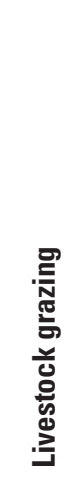 & 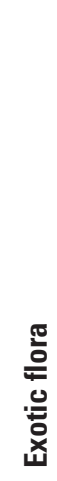 & 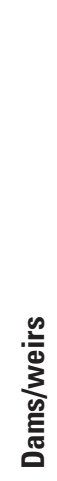 & 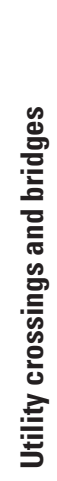 & 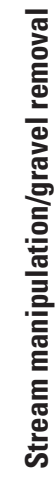 & 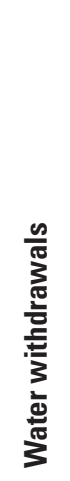 & 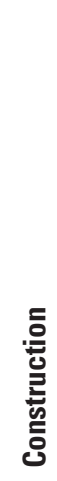 & 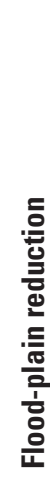 \\
\hline Highway 7 & $\mathrm{X}$ & $X$ & & $\mathrm{X}$ & & $X$ & & & & \\
\hline Baily Road & $\mathrm{X}$ & $\mathrm{X}$ & $\mathrm{X}$ & $\mathrm{X}$ & & $\mathrm{X}$ & & & & $\mathrm{X}$ \\
\hline Above Coleman Creek & $\mathrm{X}$ & $\mathrm{X}$ & $\mathrm{X}$ & & & & $\mathrm{X}$ & & & \\
\hline Coleman Creek & $\mathrm{X}$ & $\mathrm{X}$ & $\mathrm{X}$ & & & & $\mathrm{X}$ & & $\mathrm{X}$ & $\mathrm{X}$ \\
\hline Talley Cemetery Road & & $X$ & & $X$ & & $X$ & & & & \\
\hline Above Mill Creek & & $\mathrm{X}$ & & & $\mathrm{X}$ & & $\mathrm{X}$ & $X$ & & \\
\hline Mill Creek & & $\mathrm{X}$ & & & $\mathrm{X}$ & & & $\mathrm{X}$ & $\mathrm{X}$ & $\mathrm{X}$ \\
\hline Below Danville Road & $\mathrm{X}$ & $\mathrm{X}$ & $\mathrm{X}$ & & & & & & & \\
\hline Vance Road & $\mathrm{X}$ & $\mathrm{X}$ & $\mathrm{X}$ & $\mathrm{X}$ & & $\mathrm{X}$ & & & & \\
\hline
\end{tabular}

points). All bankfull indicators that could be identified, from both the left and right banks, were measured and included all relatively flat depositional areas where the flood plain meets the stream bank. The bankfull stage or elevation for each cross section was determined by visually inspecting the crosssection plot for a break in the land-surface slop occurring at or near the elevation of the best-fit regression line through the bankfull indicators upstream and downstream from the cross section in the profile view. Cross-sectional survey data provided stream geometry measurements for top width, area, wetted perimeter, maximum depth (thalweg), and stage or water-surface elevation (fig. 4). From these cross-sectional data, the mean depth and hydraulic radius were calculated (see figure 4 for definitions). All stream geometry data reported are for bankfull stage. Additionally, most cross-sectional surveys were carried to an elevation high enough to include the floodprone elevation, which is defined as twice the maximum bankfull depth (fig. 5). From the bankfull stream geometry data, the width-to-depth and entrenchment ratios were calculated (see figure 5 for definitions). Thalweg or longitudinal profile surveys were carried upstream and downstream from the cross sections approximately 10 times the bankfull stream channel width or for a total distance of approximately 20 times the bankfull stream channel width.

Along two of the study reaches (Highway 7 and Baily Road) more than one cross section was surveyed. At Highway 7 , six cross sections were measured. Data from cross sections 5 and 6 were averaged to determine bankfull characteristics and stream classification. The remaining four cross sections were conducted to define the Highway 7 Bridge and were to be used if a hydraulic computer model was constructed. A computer model was not constructed and these data were not used. Similarly, at Baily Road, two cross sections were measured and the data averaged to determine bankfull characteristics and stream classification.

At bankfull stages, the relations between drainage area and bankfull hydraulic dimensions (cross-sectional area, top width, mean depth, and discharge) have high coefficients of correlation for similar stream types within the same physiographic province. Plots of these relations between drainage area and bankfull hydraulic dimensions (regional hydraulic geometry curves) can be utilized to help assess stream hydraulic geometry within the same physiographic province.

An analysis of the Middle Fork's hydraulic geometry dimensions was conducted by comparing measured hydraulic 


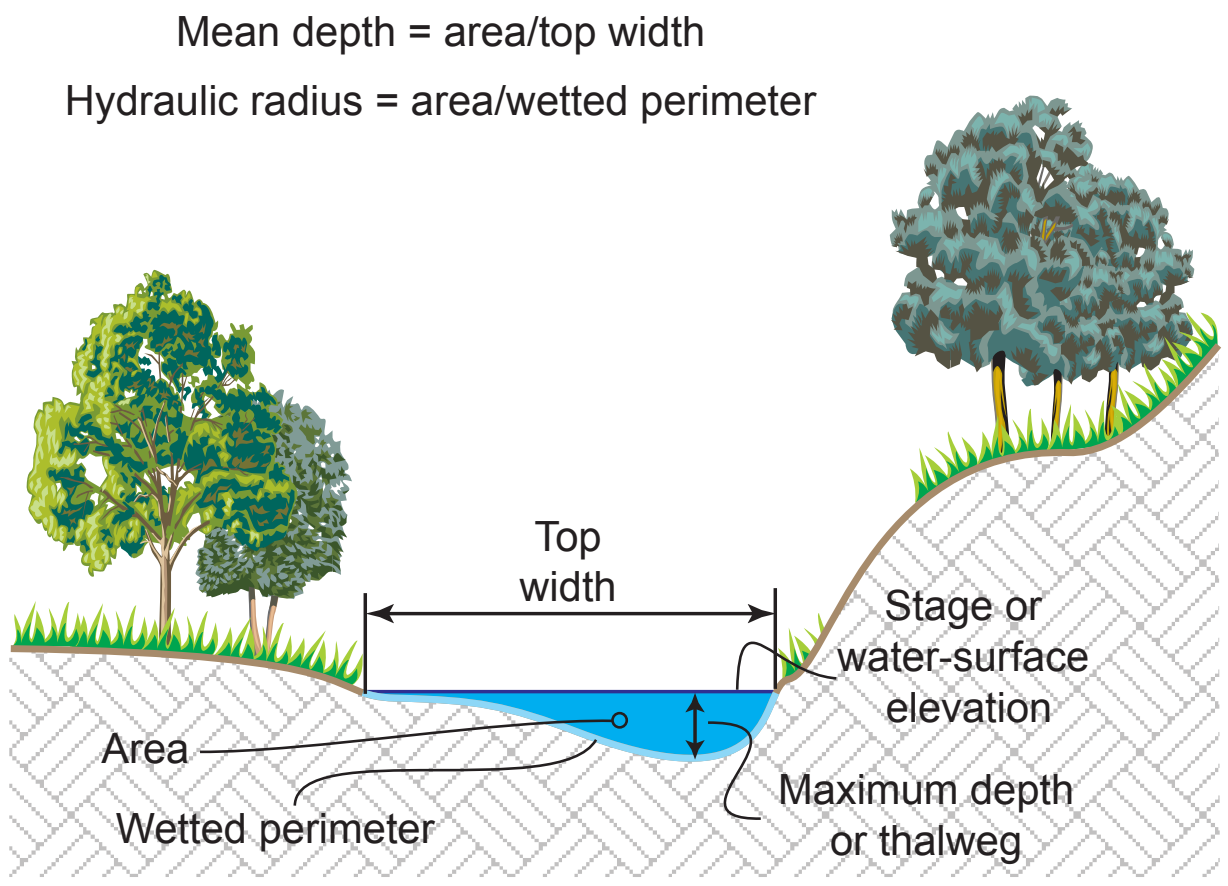

Figure 4. Channel dimensions.

Width/depth ratio $=$ bankfull top width/mean depth

Entrenchment ratio $=$ flood prone width/bankfull top width

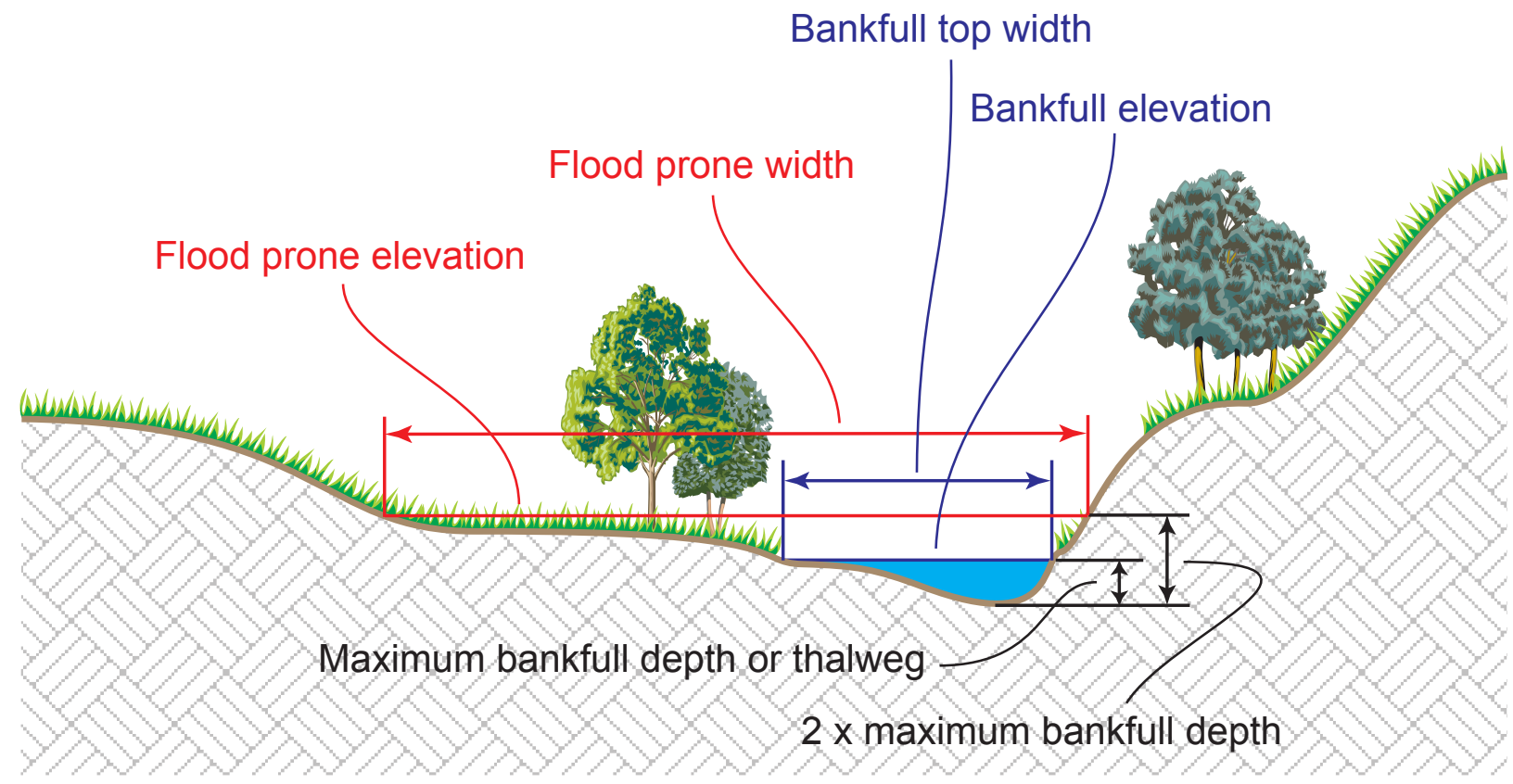

Figure 5. Bankfull and flood-prone dimensions. 
geometry dimensions to predicted dimensions from preliminary regional hydraulic geometry curves for the Ouachita Mountains Physiographic Province. The variability of the dependent dimensions (bankfull cross-sectional area, bankfull top width, bankfull mean depth, and bankfull discharge) of the preliminary Ouachita Mountains regional hydraulic geometry curves is indicated by the 95 percent confidence and prediction intervals (T.J. Garday, Natural Resources Conservation Service, written commun., 2005). Prediction intervals provide upper and lower limits of individual dependent dimensions (bankfull cross-sectional area, bankfull top width, bankfull mean depth, and bankfull discharge) predictions, whereas confidence intervals provide upper and lower limits of dependent dimensions (bankfull cross-sectional area, bankfull top width, bankfull mean depth, and bankfull discharge) of prediction population means. To aid in the assessment of the Middle Fork's hydraulic geometry data, the data are plotted with the Ouachita Mountains regional data and the percent difference between the two data sets is presented. Percent difference and total percent difference are defined as:

\section{Percent difference $=(\mid$ Middle Fork measured value - regional curve predicted value|/ regional curve predicted value) $\times 100$}

Total percent difference $=((\mid$ Middle Forked measured area - regional curve predicted area $|+|$ Middle Fork measured width - regional curve predicted width $|+|$ Middle Fork measured depth - regional curve predicted depth|)/(regional curve predicted area + regional curve predicted width + regional curve predicted depth) $) \times 100$

Additional hydraulic geometry data were obtained from individual USGS discharge measurements made at the Middle Fork Saline River below Jessieville gage (station number 07362641, at the Talley Cemetery Road bridge) and at the Middle Fork Saline River near Owensville gage (station number 07362693, at the Vance Road bridge) (data on file at USGS Arkansas Water Science Center, Little Rock, Ark.). Examination of individual discharge measurements provides cross-sectional area, top width, mean depth, and mean velocity data for the measured discharge. Plotting the measured hydraulic geometry dimensions and the measured discharge and drawing least squares regression lines through each set of dimensions yields hydraulic geometry curves for each gage.

Estimates of suspended sediment loading rates were developed for the flows passing the Middle Fork's two USGS gaging stations from the hydraulic geometry curves developed for each station from individual discharge measurements. Leopold and Maddock (1953) noted that the rates of change in hydraulic geometry variables dimensions (width, mean depth, mean velocity, and suspended load) with changes in discharge are defined by the slopes of the lines in the following equations and are equal to the exponents $\mathrm{b}, \mathrm{m}, \mathrm{f}$, and $\mathrm{j}$.

$$
w=a Q^{b}, d=c Q^{f}, u=k Q^{m}, \text { and } L=p Q^{j}
$$

where $w$ is width, in feet;

$d$ is mean depth, in feet;

$u$ is mean velocity, in feet per second; and

$L$ is suspended sediment load, in tons per day.

$a, c, k$, and $p$ are numerical constants of the coefficient at unit discharge for width, mean depth, mean velocity, and suspended sediment load, respectively,

$Q$ is discharge, in cubic feet per second, and,

$b, f, m$, and $j$ are numerical constants of the slopes in the lines for width, mean depth, mean velocity, and suspended sediment load, respectively.

Note: $b+f+\mathrm{m}=1.0$ and $a \times c \times k=1.0$ as required by the identity $Q=w \times d \times u$.

The numerical constants a, c, k, b, f, and m were derived form the hydraulic geometry curves developed for the two USGS gaging station from the least-square best fit lines of the top width ( $\mathrm{a}$ and $\mathrm{b}$ ), mean depth (c and f), and mean velocity ( $\mathrm{k}$ and $\mathrm{m}$ ) curves. The slope of the suspended load and discharge curve (j), or the suspended sediment loading rate, was obtained from figure 18 of USGS Professional Paper 252 (Leopold and Maddock, 1953). The suspended sediment loading rate was determined by calculating the ratio of slopes of mean velocity and discharge curve and mean depth and discharge curve $(\mathrm{m} / \mathrm{f})$, and using the slope of the top width and discharge curve (b) to read the estimated slope of the suspended-sediment rating curve (j) from figure 18 for the data from each of the two gaging stations.

\section{Streambed Sediment}

The composition of streambed sediment is an important factor in how a stream responds to changes in slope or discharge or both. The most efficient technique for measuring the distribution of streambed-sediment size is the Wolman pebble count (Wolman, 1954). Pebble counts were conducted across the riffles using the step-toe procedure to collect approximately 100 samples for each study reach. Only materials from the active streambed were measured. For each sample selected, the intermediate (B) axis was measured and recorded (fig. 6).

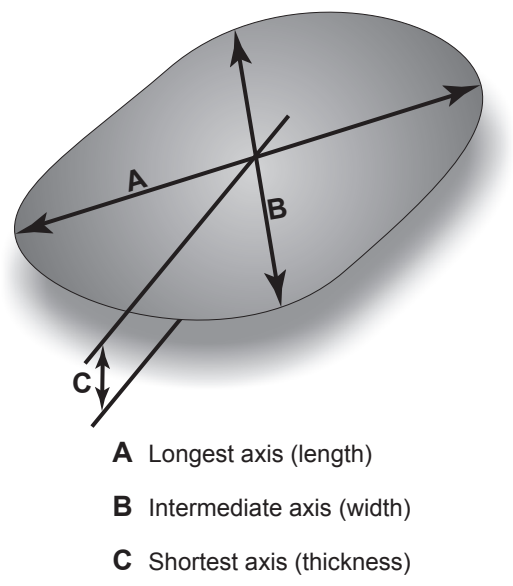

Figure 6. Pebble axis. 
From the pebble count data, the bedrock tallies were removed and cumulative frequency curves were developed, the median (D50) and one standard deviation from the median (D16 and D84) particle sizes were determined. Bedrock is defined as any exposure of native solid rock in the streambed or along the streambanks.

Tractive Force for incipient motion or shear stress and the maximum particle size moved during bankfull flows also were calculated for each cross section. Newbury and Gaboury (1993) developed the following equation to characterize the average shear stress in a stream reach. Using the hydraulic radius and profile slope data from each study reach's crosssection survey, the average bankfull tractive forces for each cross section was calculated using the Newbury and Gaboury's equation.

$$
\tau=\gamma \times r \times s
$$

where $\tau$ is tractive force of flow (pound force per square foot) $\gamma$ is specific weight of water (62.4 pound per cubic foot) $r$ is hydraulic radius (feet), and

$s$ is energy slope (feet/feet).

From field observations Lane (1955) compiled recommended design guidelines for tractive force and related them to the size of material at incipient motion. For non-cohesive bed materials greater than 0.394 inches $(10 \mathrm{~mm})$ in diameter (fine gravel), the relation is:

Particle diameter at incipient motion (in) $=\tau \times 2$ (gravel equation, Lane, 1955)

The particle size transported during bankfull flow events at each study reach was calculated by applying the results from the bankfull tractive force calculations to Lane's particle diameter equation.

\section{Sinuosity}

The degree to which a channel meanders can be expressed by its sinuosity. Sinuosity $(\mathrm{K})$ is determined using the ratio:

$$
\mathrm{K}=\text { channel length / valley length }
$$

Stream and valley lengths were measured upstream from the downstream end of each study reach for approximately 2 meander wavelengths or roughly 20 to 30 times the channel's bankfull top width. Stream lengths were measured twice for each reach using a geographic information system to delineate the streamflow paths from 1992 and 2002 digital aerial imagery, while the centerline of the valley was delineated from digital raster graphic imagery of 1:24,000-scale USGS topographic maps.

\section{Stream Reach Classification}

Each of the study reaches were classified using a stream reach classification system developed by Rosgen (1994). Classification is based on stream form and pattern. Specifically, the classification is determined using the entrenchment ratio, the width to depth ratio, sinuosity, slope, and median streambed particle size measured at each study reach. Because a stream may vary in character over a relatively short distance, the Rosgen classification system describes individual reaches and not the entire stream system.

\section{Photographs}

For basic documentation, digital photographs were taken at all cross sections. The photographs include views looking along the centerline of the cross section at the left and right banks, and upstream and downstream.

\section{Geomorphic Characterization}

The following discussions are a summarization of the data collected from nine study reach locations along the upper parts of the Middle Fork. Characterization includes discussions of hydraulic geometry, streambed sediment, sinuosity, and stream reach classification. A summary of channel geometry characteristics by study reach is presented in table 3. Geomorphic characteristics by study reach are provided in appendixes 1-9 at the back of the report.

\section{Hydraulic Geometry}

An analysis of the Middle Fork's hydraulic geometry was, in part, conducted by comparing measured hydraulic geometry dimensions to predicted dimensions from preliminary regional hydraulic geometry curves for the Ouachita Mountains physiographic province. The preliminary Ouachita Mountains regional hydraulic geometry curves with 95 percent confidence and prediction intervals are presented in figure 7 (T.J. Garday, Natural Resources Conservation Service, written commun., 2005). To aid in the assessment, the Middle Fork's hydraulic geometry data are plotted with the Ouachita regional data in figure 8 and the percent difference between the two data sets are presented in table 4 .

When compared to the Ouachita Mountains regional curves (fig. 8, table 4), the Talley Cemetery Road reach most closely matches the hydraulic geometry curve values with a total percent difference value of 2.9 percent. The bankfull cross-sectional area, top width, and mean depth fall on or near the regional curve values for a basin with a $29.9-\mathrm{mi}^{2}$ drainage area, indicating that the reach is as stable and in balance 


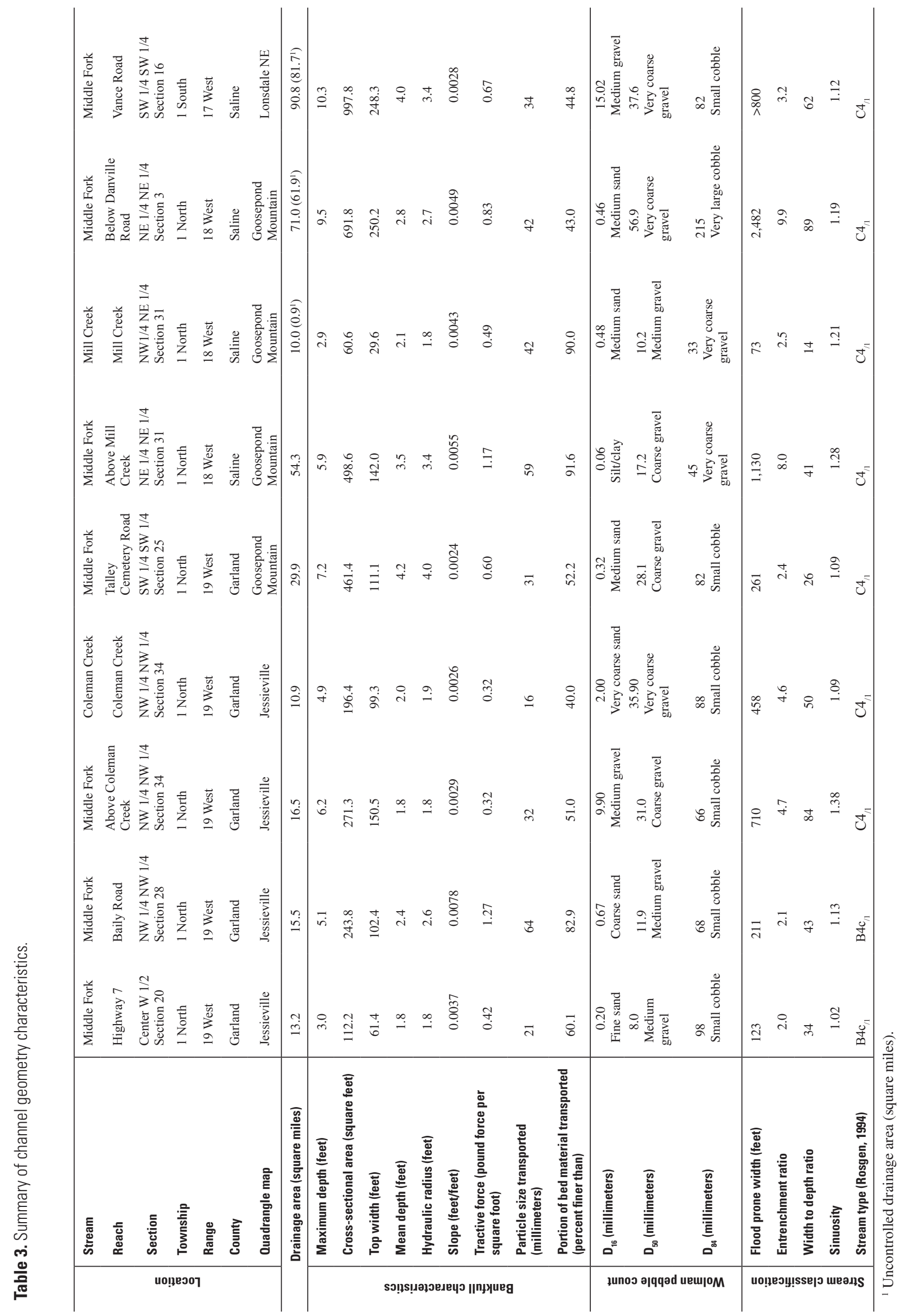



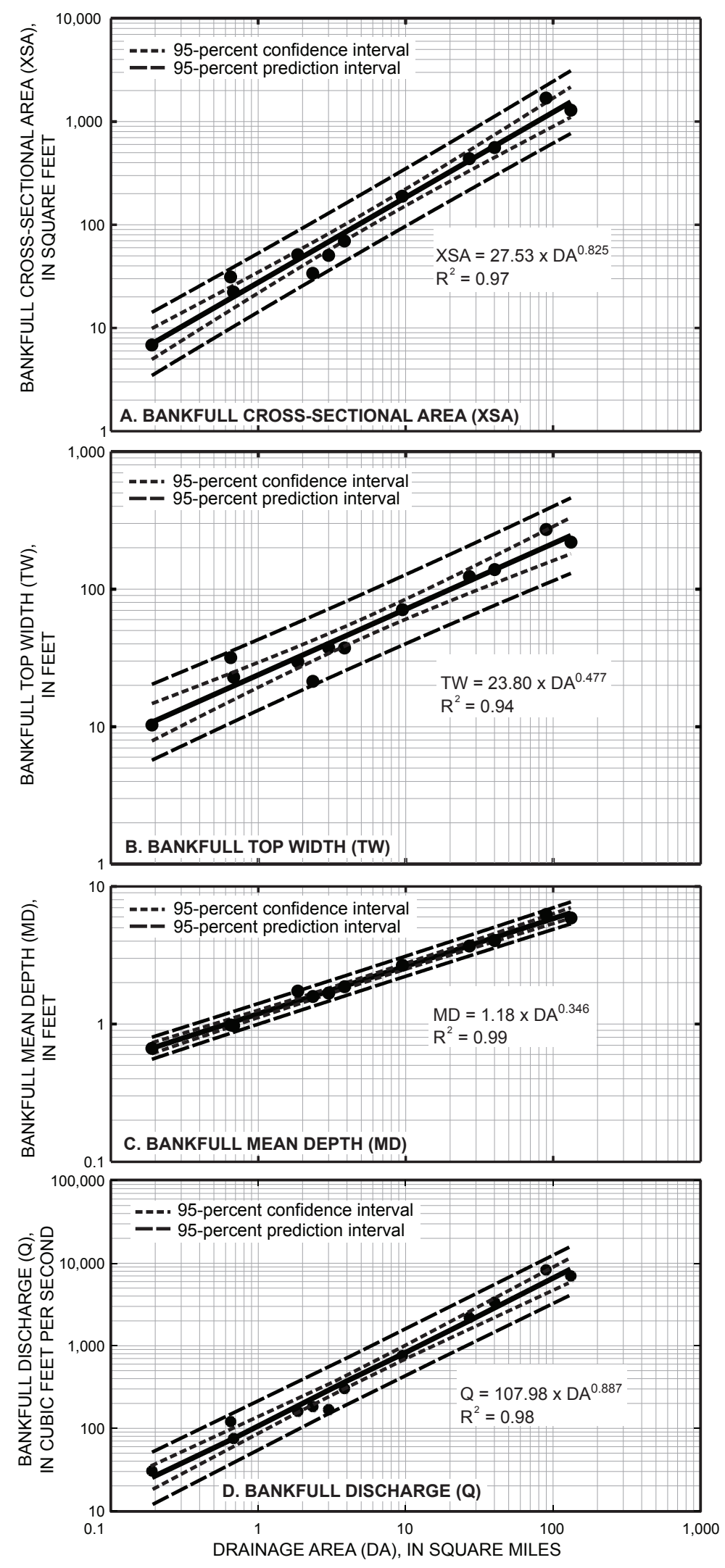

Figure 7. Preliminary bankfull channel dimensions as a function of drainage area for streams in the Ouachita Mountains of Arkansas and Oklahoma, with 95 percent prediction and confidence intervals. 


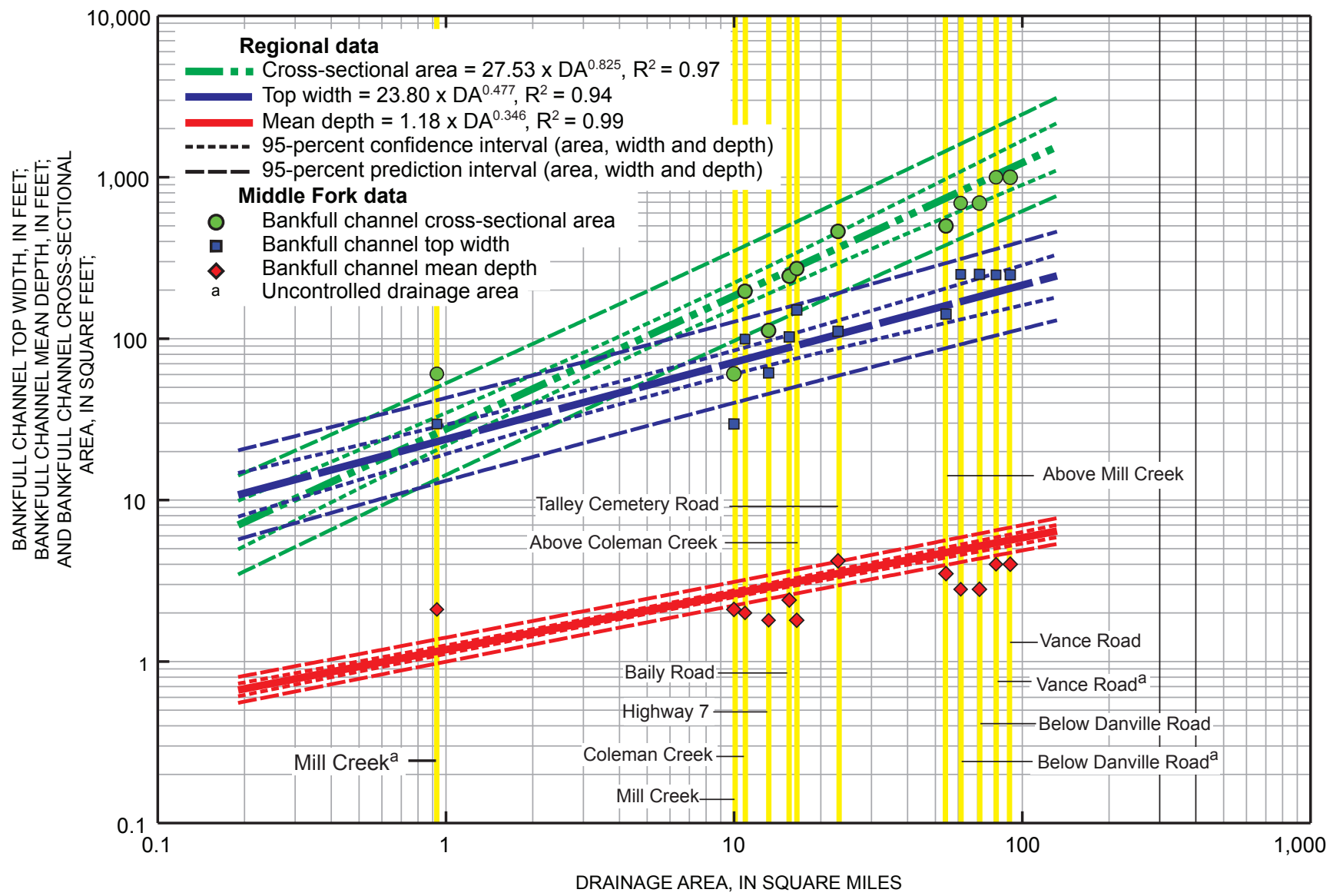

Figure 8. Preliminary regional hydraulic geometry curves for the Ouachita Mountains of Arkansas and Oklahoma and reach data from the Middle Fork Saline River. 


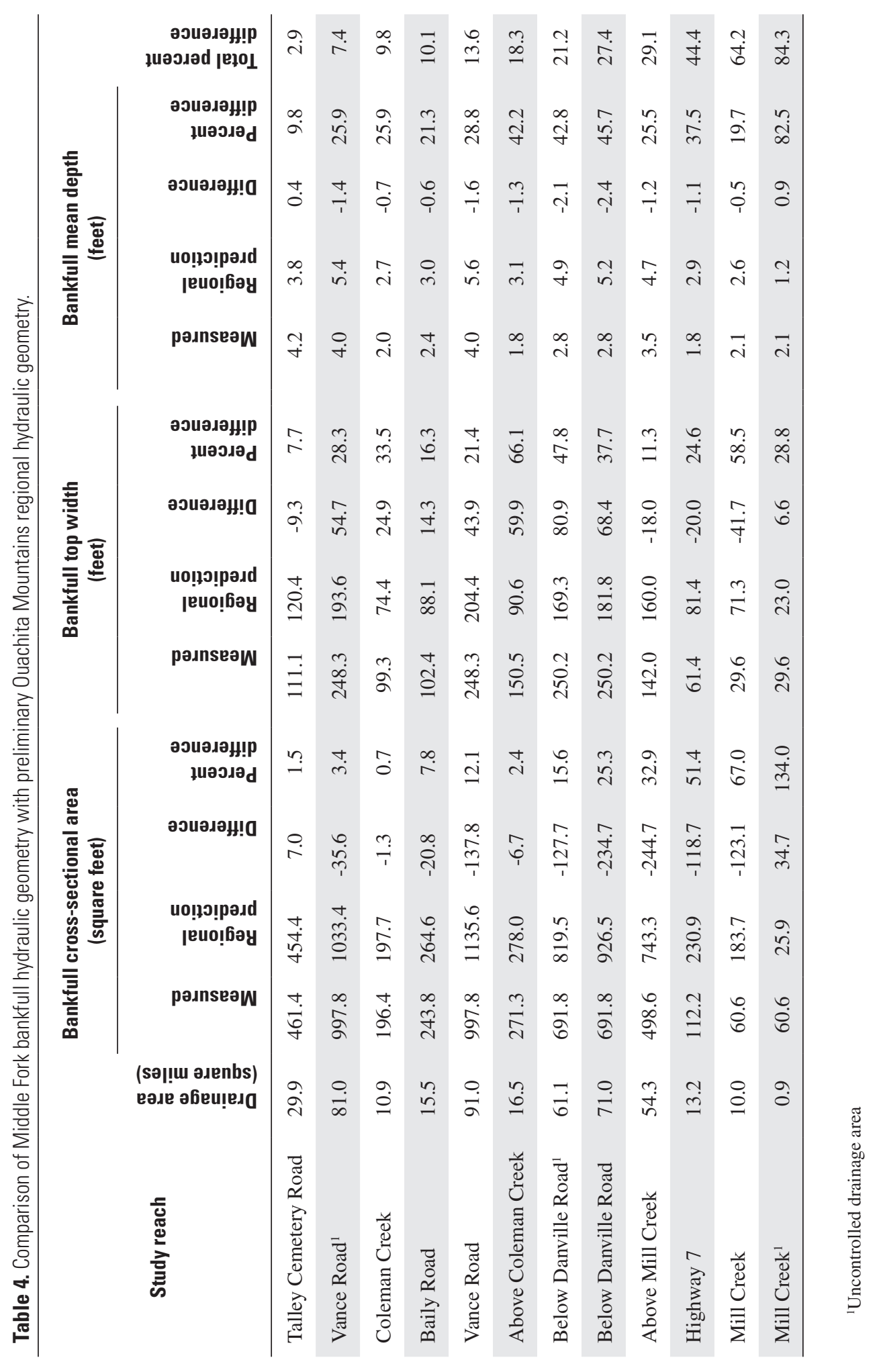


with respect to water and sediment discharge as other natural streams in the Ouachita Mountains physiographic province.

The Mill Creek reach is geometrically oversized for a basin with its drainage area and has the greatest divergence from the Ouachita Mountains regional hydraulic geometry curves of any of the reaches examined. Using the total, partially controlled drainage area of $10.0 \mathrm{mi}^{2}$, the total percent difference was 64.2 percent and the geometry data plotted below the regional curves indicating that Mill Creek is geometrically undersized for this size drainage area (fig. 8, table 4). Using an uncontrolled drainage area of $0.9 \mathrm{mi}^{2}$, the total percent difference was 84.3 percent and the geometry data plotted above the regional curves indicating that Mill Creek is geometrically oversized for this size drainage area. Back-calculating the equivalent drainage area that produces the minimal total percent error for the measured Mill Creek hydraulic geometry dimensions gives an equivalent drainage area of 2.6 $\mathrm{mi}^{2}$, with a total percent difference of 8.5 percent. Together, these data indicate Mill Creek is adjusting its hydraulic geometry to a smaller uncontrolled drainage area resulting from the construction of a series of dammed lakes built within the basin over the past 30 years. Because the dams are releasing flow from the upper, controlled part of the basin, Mill Creek may always be geometrically (area, width, and depth) oversized with respect to the $0.9 \mathrm{mi}^{2}$ uncontrolled part of the drainage basin. It may take decades for Mill Creek to construct a new channel and flood plains at the appropriate dimensions and elevations considering the small size of the uncontrolled part of the drainage basin and the lack of sediment passing through the dams.

Reaches at Highway 7 and Above Mill Creek both have bankfull cross-sectional area, top width, and mean depth values considerably smaller than what the Ouachita Mountains regional hydraulic geometry curves predict. At the Highway 7 reach, the cross-sectional area is $118.7 \mathrm{ft}^{2}$ less $(51.4$ percent difference), the top width is $20.0 \mathrm{ft}$ narrower (24.6 percent difference), and the mean depth is $1.1 \mathrm{ft}$ shallower (37.5 percent difference) than what the Ouachita regional hydraulic geometry curves predict (fig. 8, table 4). At the Above Mill Creek reach, the cross-sectional area is $244.7 \mathrm{ft}^{2}$ less $(32.9$ percent difference), the top width is $18.0 \mathrm{ft}$ narrower (11.3 percent difference), and the mean depth is $1.2 \mathrm{ft}$ shallower (25.5 percent difference) than what the Ouachita regional hydraulic geometry curves predict (fig. 8, table 4). This indicates that both sites are geometrically undersized for their drainage areas. This suggests one or a combination of three possibilities: (1) velocities are higher, reducing the cross-sectional area needed for similar discharges, (2) sediment size has decreased, or (3) sediment discharge has decreased.

Both the Highway 7 and Above Mill Creek sites have structural influences just upstream from their reaches that may be affecting their geometry. Upstream from the Highway 7 reach, a ridge of Arkansas Novaculite and the State Highway 7 bridge are pinching the valley width preventing the Middle Fork from meandering freely and reducing available flood plain needed for energy dissipation. The effect of this valley pinching is to decrease sinuosity, increasing slope and water velocity, and thus reduce hydraulic geometry dimensions (area, width, and depth). Water is being withdrawn from the Middle Fork at a low water weir approximately one-half mile upstream from the Above Mill Creek reach. The effect of the reduced flow would be reduced hydraulic geometry dimensions (area, width, and depth). The weir also attenuates flows and traps sediments at stages below the weir crest. This may not mean these reaches are unstable, only that the reach conditions at these two sites are different from the reach conditions used to develop the Ouachita Mountains hydraulic geometry regional curves. Conclusions for these two sites can not be based on regional curve comparisons because of these differences in site conditions.

The remaining five Middle Fork study reaches-Baily Road, Above Coleman Creek, Coleman Creek, Below Danville Road, and Vance Road-all have cross-sectional areas smaller than, top widths greater than, and mean depths shallower than the Ouachita Mountains hydraulic geometry regional curve values for basins with their respective drainage areas predict (fig. 7, table 4). This suggests one or a combination of three possibilities: (1) the Middle Fork is receiving and transporting more streambed sediment, (2) the Middle Fork is receiving and transporting larger streambed sediment, and (3) the Middle Fork is receiving smaller volumes of water, relative to the streams used to develop the Ouachita Mountains regional hydraulic geometry curves.

Analysis of hydraulic geometry data developed from discharge measurements made by the USGS at the Middle Fork Saline River below Jessieville gage (station number 07362641, at the Talley Cemetery Road bridge) and at the Middle Fork Saline River near Owensville gage (station number 07362693, at the Vance Road bridge) indicates that with similar increases in discharge, the estimated change in suspended-sediment loads at the Vance Road bridge are greater and increasing at a faster rate than at the Talley Cemetery Road bridge (table 5, fig. 9).

Table 5. Comparison of estimated changes in suspended sediment with changes in discharge at two U.S. Geological Survey stream gaging stations-Middle Fork Saline River below Jessieville (07362641) and Middle Fork Saline River near Owensville (07362693).

\begin{tabular}{|c|c|c|c|}
\hline \multicolumn{2}{|c|}{$\begin{array}{c}\text { Middle Fork Saline River } \\
\text { below Jessieville, Arkansas } \\
\text { (07362641), } \\
\text { Talley Cemetery Road bridge }\end{array}$} & \multicolumn{2}{|c|}{$\begin{array}{c}\text { Middle Fork Saline River } \\
\text { near Owensville, Arkansas } \\
\text { (07362693), } \\
\text { Vance Road bridge }\end{array}$} \\
\hline $\begin{array}{l}\text { Increase } \\
\text { in discharge } \\
\text { (cubic feet } \\
\text { per second) }\end{array}$ & $\begin{array}{l}\text { Estimated } \\
\text { increase in } \\
\text { suspended- } \\
\text { sediment load } \\
\text { (tons per day) }\end{array}$ & $\begin{array}{l}\text { Increase } \\
\text { in discharge } \\
\text { (cubic feet } \\
\text { per second) }\end{array}$ & $\begin{array}{l}\text { Estimated } \\
\text { increase in } \\
\text { suspended- } \\
\text { sediment load } \\
\text { (tons per day) }\end{array}$ \\
\hline 10 & 794 & 10 & 7,943 \\
\hline 100 & 630,957 & 100 & $63,095,734$ \\
\hline 1,000 & $501,187,234$ & 1,000 & $501,187,233,627$ \\
\hline
\end{tabular}




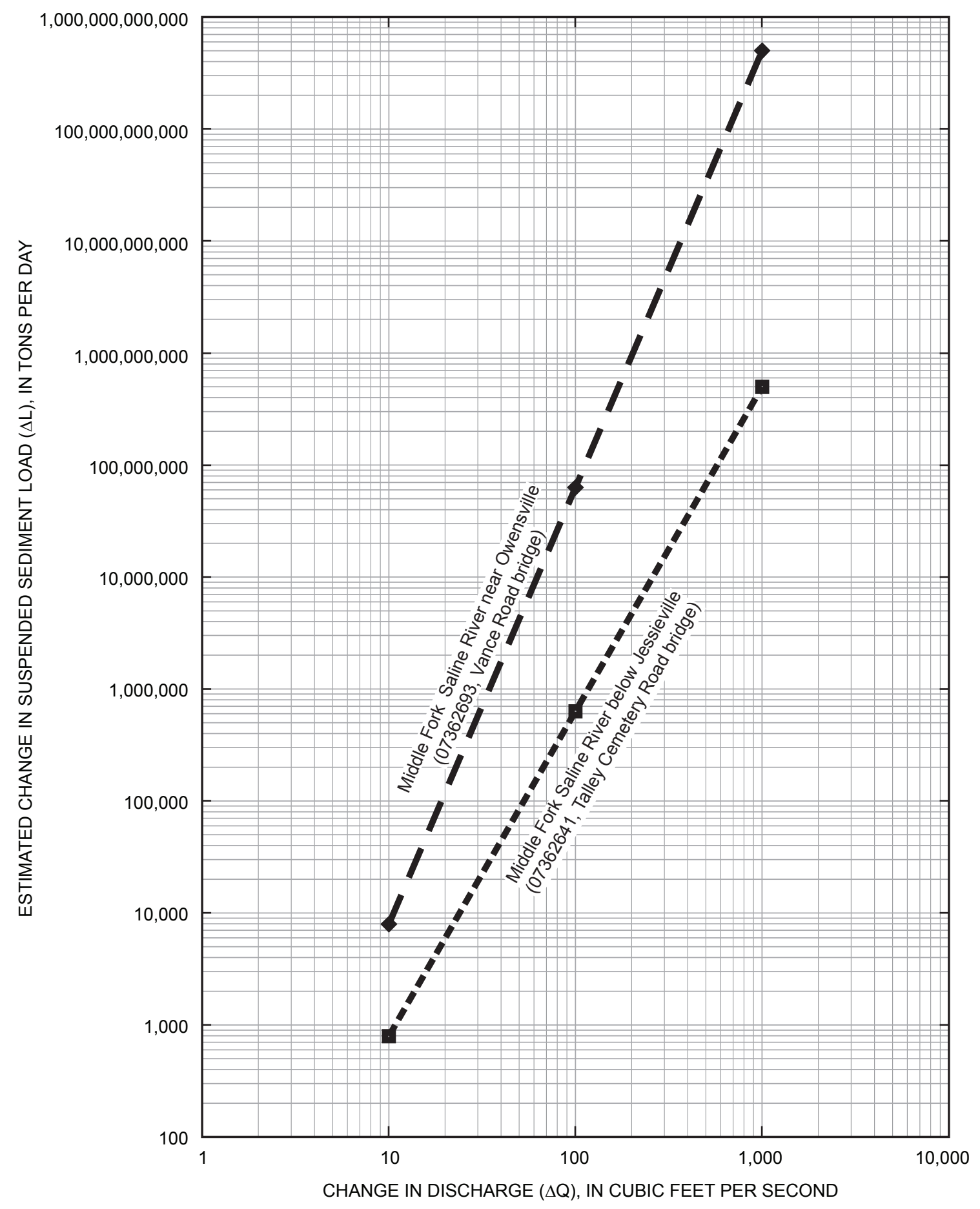

Figure 9. Estimated changes in suspended sediment with changes in discharge for two U.S. Geological Survey stream gaging stations-Middle Fork Saline River below Jessieville and Middle Fork Saline River near Owensville. 
Graphs of hydraulic geometry variables (cross-sectional area, top width, mean depth, and mean velocity) plotted against discharge for the two Middle Fork USGS gaging stations are presented in figure 10 . The numerical constants $\mathrm{b}, \mathrm{f}, \mathrm{m}, \mathrm{a}, \mathrm{c}$, and $\mathrm{k}$ were derived from the least-square best fit lines through the hydraulic geometry data, and also are presented in figure 10 and in table 6 . The slope of the suspended sediment and discharge line (j) was obtained from Leopold and Maddock (1953, fig. 18) by calculating the ratio of slopes of the mean velocity against discharge line and mean depth against discharge lines (m/f), and using the slope of the top width against discharge line (b) to read the estimated slope of the suspended sediment line (j). The values for $\mathrm{m} / \mathrm{f}$ and $\mathrm{j}$ also are presented on the hydraulic geometry graphs (fig. 10) and in table 6.
Based on the measured discharge data from the gages below Jessieville (at Talley Cemetery Road bridge, fig. 10A) and near Owensville (at Vance Road bridge, fig. 10B), the slopes of the suspended-sediment load against discharge lines (j) are estimated to be 2.9 and 3.9, respectively. Because the constant $\mathrm{p}$ is unknown, the rates of change of suspendedsediment load $(\Delta L)$ to changes in discharge $(\Delta Q)$ are examined substituting $\Delta L$ for $L$ and $\Delta Q$ for $Q$ into Leopold's equation $L=p \times Q^{j}$ to become $\Delta L=\Delta Q^{j}$. For a $10 \mathrm{ft}^{3} / \mathrm{s}$ increase in discharge $(\Delta Q)$ passing the Vance Road bridge (gage near Owensville), the suspended-sediment load $(\Delta L)$ will increase by approximately 8,000 tons per day; while for the same increase in discharge ( $\left.\Delta Q=10 \mathrm{ft}^{3} / \mathrm{s}\right)$ passing the Talley Cemetery Road bridge (gage below Jessieville), the suspended-

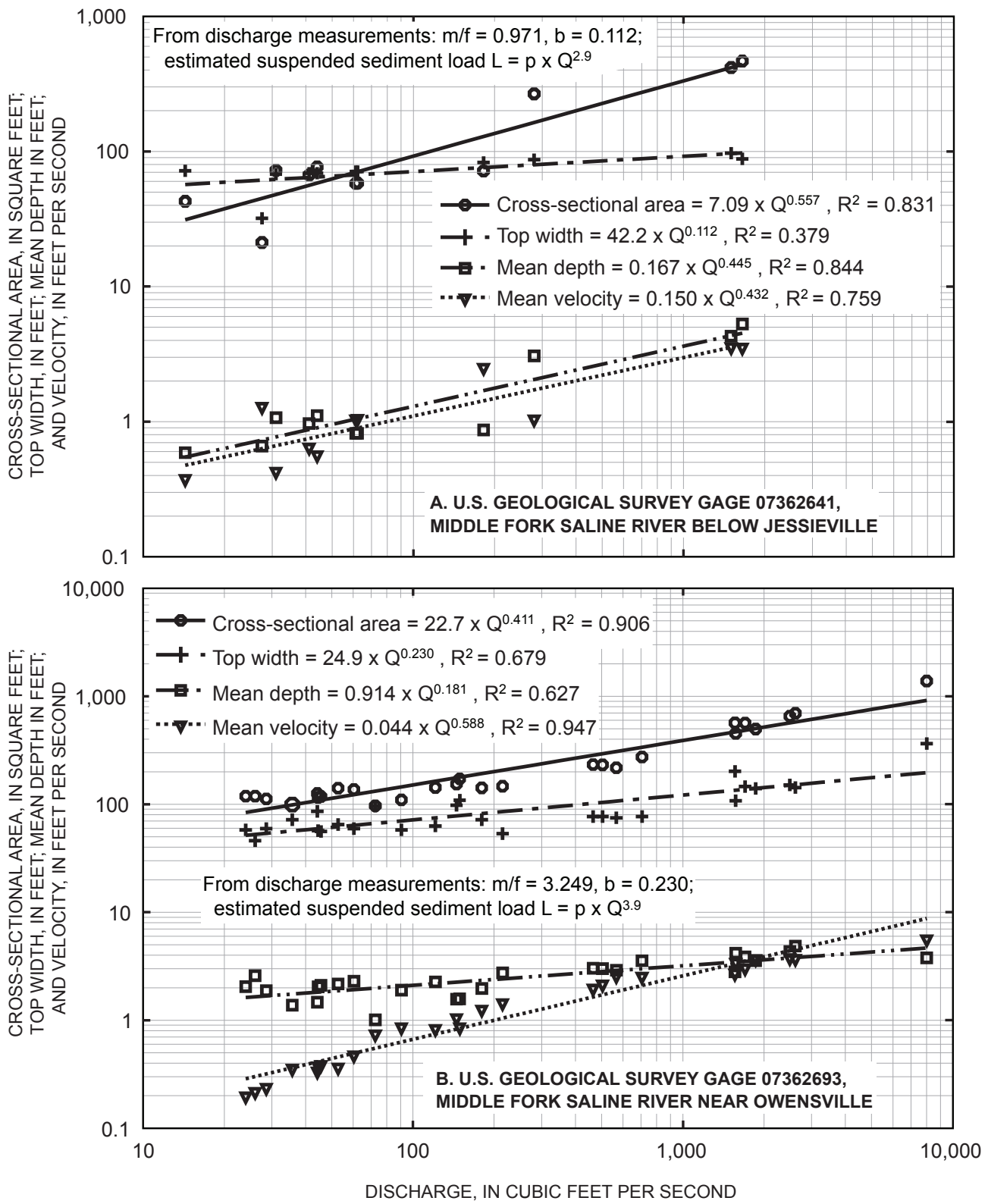

Figure 10. Stream hydraulic geometry from U.S. Geological Survey discharge measurements. 
Table 6. Comparison of Middle Fork hydraulic geometry dimensions from two U.S. Gelogical Survey stream gaging stations-Middle Fork Saline River below Jessieville (07362641) and Middle Fork Saline River near Owensville (07362693).

\begin{tabular}{lccc}
\hline \multicolumn{1}{c}{ Dimension } & $\begin{array}{c}\text { Coefficient } \\
\text { exponent }\end{array}$ & Jessieville & Owensville \\
\hline WIDTH $=\mathrm{a} \times \mathrm{Q}^{\mathrm{b}}$ & $\mathrm{a}$ & 42.2 & 24.9 \\
$\mathrm{DEPTH}=\mathrm{c} \times \mathrm{Q}^{\mathrm{f}}$ & $\mathrm{b}$ & 0.112 & 0.230 \\
& $\mathrm{c}$ & 0.167 & 0.914 \\
$\mathrm{VELOCITY}=\mathrm{k} \times \mathrm{Q}^{\mathrm{m}}$ & $\mathrm{f}$ & 0.445 & 0.181 \\
\hline $\mathrm{b}+\mathrm{f}+\mathrm{m}=1.0^{1}$ & $\mathrm{k}$ & 0.150 & 0.044 \\
$\mathrm{a} \times \mathrm{c} \times \mathrm{k}=1.0^{1}$ & $\mathrm{~m}$ & 0.432 & 0.588 \\
\hline Shear stress rate factor & & 0.989 & 0.999 \\
Estimated sediment load rate & & 1.057 & 1.001 \\
\hline
\end{tabular}

${ }^{1}$ As required by the identity: discharge $(\mathrm{Q})=$ width $\mathrm{x}$ depth $\mathrm{x}$ velocity.

sediment load $(\Delta L)$ will increase by approximately 800 tons per day. Similarly, for a $100 \mathrm{ft}^{3} / \mathrm{s}$ increase in discharge $(\Delta Q)$ passing the Vance Road bridge (gage near Owensville), the suspended-sediment load $(\Delta L)$ will increase by approximately $63,000,000$ tons per day; while for the same increase in discharge $\left(\Delta Q=100 \mathrm{ft}^{3} / \mathrm{s}\right)$ passing the Talley Cemetery Road bridge (gage below Jessieville), the suspended-sediment load $(\Delta L)$ will increase by approximately 630,000 tons per day. Together these data indicate that for the same discharge, more suspended sediment will flow pass the Vance Road bridge (gage near Owensville), than will flow past the Talley Cemetery Road bridge (gage below Jessieville), and that as discharge increases, the amount of suspended sediment passing under the Vance Road bridge (gage near Owensville) will increase at a faster rate than the amount of suspended sediment passing under the Talley Cemetery Road bridge (gage below Jessieville).

Note, the numbers presented above and in table 5 and figure 9 , for changes in suspended-sediment load $(\Delta L)$ because of changes in discharge $(\Delta Q)$, are to illustrate relative rates of change and are not the expected suspended-sediment loads. To estimate the suspended-sediment load $(L)$, the change in suspended-sediment load $(\Delta L)$ is multiplied by the numerical constant $p\left(L=p \times Q^{j}\right)$. At this time there are insufficient suspended-sediment measurements at these gages to calculate $p$. Expected $p$ values range from 0.001 to 0.000007 for streams similar to the Middle Fork.

Additional examination of the hydraulic geometry from the gage data indicates that the shear stresses acting on the streambed at the Vance Road bridge are rapidly increasing with increasing discharge while the shear stresses at the Talley Cemetery Road bridge remain relatively constant with increas- ing discharge. The force exerted on bed-sediment particles is caused by the shearing of the fluid. The relative shear stress $(\tau)$ between any two thin sheets of fluid may be expressed by using Newton's equation of viscosity: $\tau=\mu d u / d y$, where $\tau$ is shear stress, $\mu$ is a constant coefficient of viscosity, $d u$ is change in velocity, and $d y$ is change in depth (Vanoni, 1975). Examining the hydraulic geometry data from the gage below Jessieville (at Talley Cemetery Road, fig 10A), note that the slopes of the best-fit lines for mean depth and mean velocity are parallel and near equal, where $f=0.445$ and $m=0.432$. Substituting $m$ for $d u$ and $f$ for $d y, d u / d y$ is approximately 1 , indication that the shear stresses acting on the bed at Talley Cemetery Road remain approximately constant with changes in discharge. A similar examination of the hydraulic geometry data for the gage near Owensville (at Vance Road, fig. 10B) $f=0.181$ and $m=0.588$ leads to $d u / d y$ of approximately 3.25 , indicating that the shear stresses acting on the bed at Vance Road are rapidly increasing with discharge. This analysis confirms the evaluation of the study reaches using the Ouachita Mountain regional hydraulic geometry curves. That is, the reach at Talley Cemetery Road is in equilibrium with the flow regime, while the reach at Vance Road is not in equilibrium with the flow regime having overly wide and shallow dimensions resulting in rapidly increasing streambed shear stresses with increasing discharge.

\section{Streambed Sediment}

The Middle Fork is a bedrock influenced, gravel dominated stream with lesser amounts of sand and cobbles (see streambed grain-size cumulative percentage plots in appen- 
dixes). Bedrock was noted at all nine sampling reach locations and was particularly prevalent along the two upstream reaches at Highway 7 and Baily Road. Upstream from the Highway 7 sampling reach the Middle Fork's valley narrows as it passes through a ridge of Arkansas Novaculite. At the Baily Road reach the Middle Fork's streambed is dominated by an outcrop of Womble Shale.

Much of the streambed sediment in the Middle Fork is estimated to be in motion during bankfull flow events (fig. 11, table 7). At six of the nine stream reaches sampled along the Middle Fork, the tractive force values are greater than the measured median $\left(\mathrm{D}_{50}\right)$ streambed sediment size (Highway 7 , Baily Road, Above Coleman Creek, Talley Cemetery Road, Above Mill Creek, and Mill Creek), indicating that a majority of the streambed particles are subject to movement during bankfull flow events (fig. 11).

At the remaining three stream reaches (Coleman Creek, Below Danville Road, and Vance Road), the tractive force values were less than the measured median streambed sediment sizes $\left(\mathrm{D}_{50}\right)$ indicating that less than 50 percent of the streambed particles are subject to movement during bankfull flow events. At the Coleman Creek and Vance Road sites the slope values (0.0026 and 0.0028 , respectively) are relatively gentle. Because the calculated tractive force $(\tau=\gamma \times r \times s)$ values are proportional to slope, the gentle slope values produce lower tractive force values. At the Below Danville Road study site, the Middle Fork is against Goosepond Mountain, where talus was observed in the stream. The effect of the talus at this location was to increase the median $\left(\mathrm{D}_{50}\right)$ streambed sediment size and accordingly reduce the proportion of streambed sediment in motion during bankfull flow events (fig. 11).

Typical sources of sediment into river systems include sheet and rill erosion off of the uplands, streambed degradation of tributaries joining the river, gully erosion, flood-plain scour, streambed degradation in the main channel, and streambank erosion or failure (Leopold, 1994). The amount of sorting (for example, standard deviation or particle size uniformity) was calculated using the formula: graphic geometric sorting $(\mathrm{Sg})$ $=\left(\mathrm{D}_{84} / \mathrm{D}_{16}\right)^{1 / 2}$, and is illustrated by the relative divergence between the $\mathrm{D}_{84}$ and $\mathrm{D}_{16}$ particle size values (fig. 11). When the sorting value is relatively small, the streambed materials are considered very well sorted or well sorted, and when the sorting value is relatively large, the streambed materials are considered extremely poorly sorted or poorly sorted. Moving in the downstream direction, if no new sediment sources are introduced into the stream, streambed materials become more sorted with distance from the initial sediment source.

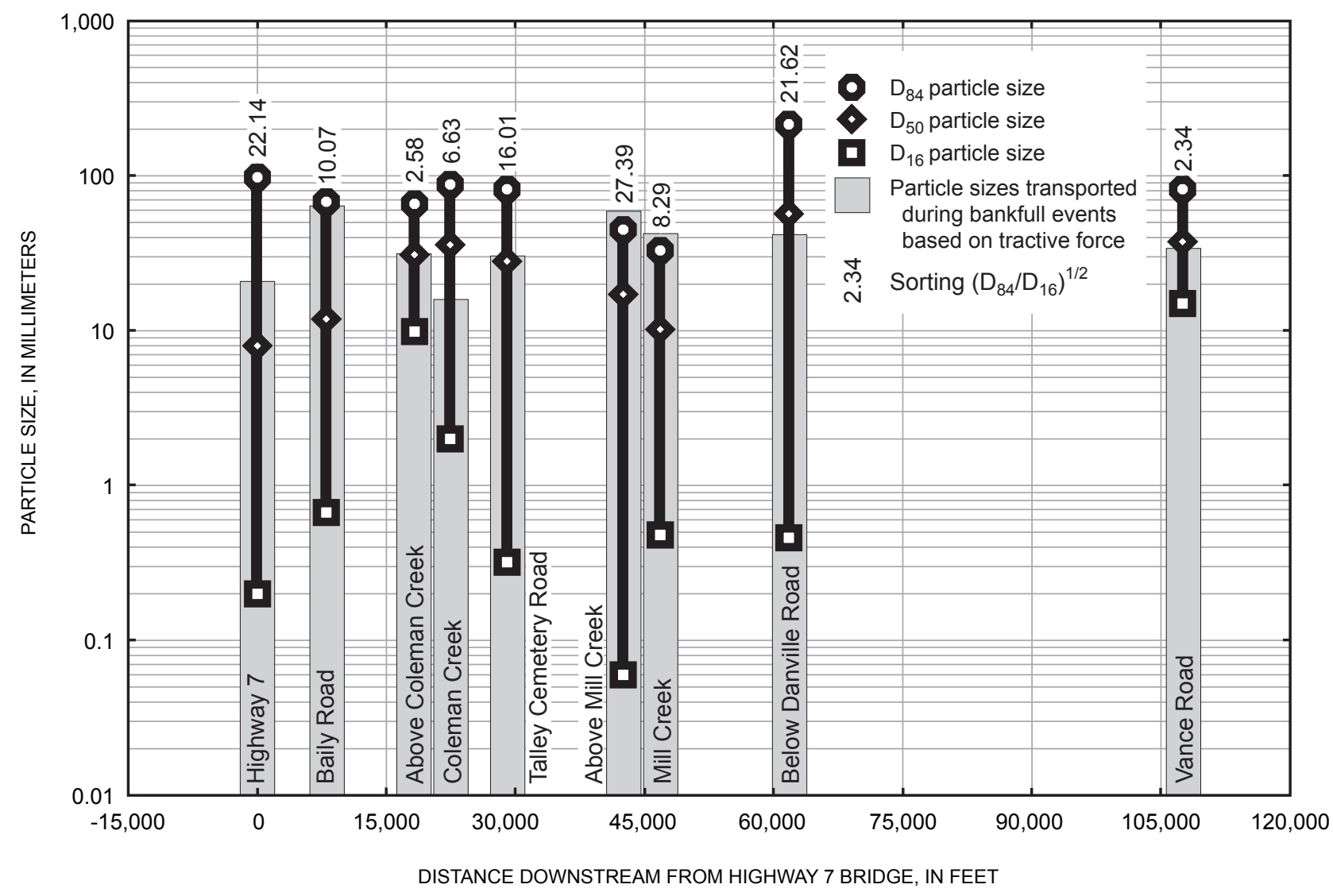

Figure 11. Middle Fork Saline River streambed material analysis of particle size, tractive force, sorting, and location. 
Table 7. Middle Fork streambed material analysis of particle size, tractive force, sorting, and location.

\begin{tabular}{|c|c|c|c|c|c|c|c|c|c|c|}
\hline Reach & 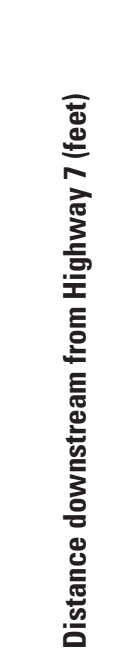 & 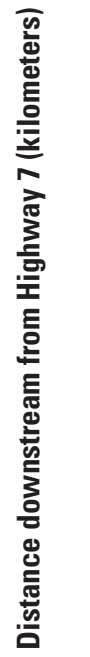 & 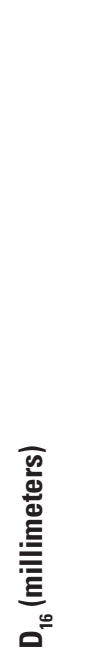 & 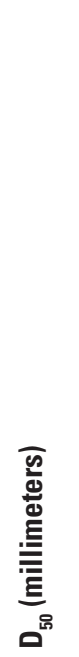 & 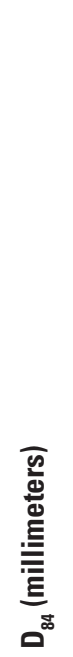 & 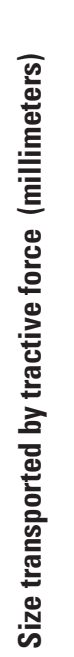 & 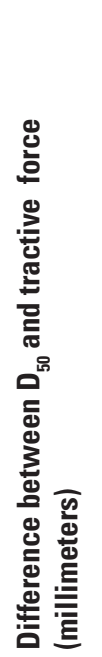 & 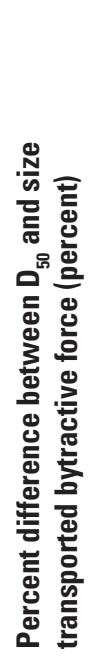 & 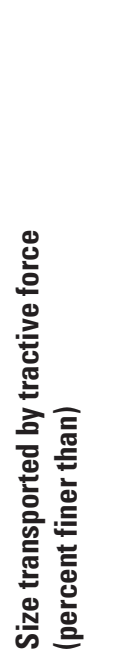 & 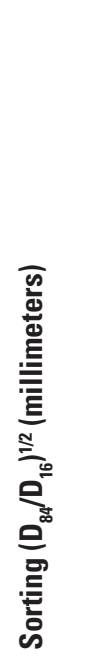 \\
\hline Highway 7 & 0 & 0 & 0.20 & 8.0 & 98 & 21 & -13.0 & 61.9 & 60.1 & 22.14 \\
\hline Baily Road & 8,000 & 2.4 & 0.67 & 11.9 & 68 & 64 & -52.1 & 81.4 & 82.9 & 10.07 \\
\hline Above Coleman Creek & 18,250 & 5.5 & 9.90 & 31.0 & 66 & 32 & -1.0 & 3.1 & 51.0 & 2.58 \\
\hline Coleman Creek & 21,750 & 6.6 & 2.00 & 35.9 & 88 & 16 & 19.9 & 55.4 & 40.0 & 6.63 \\
\hline Talley Cemetery Road & 29,000 & 8.8 & 0.32 & 28.1 & 82 & 31 & -2.9 & 9.4 & 52.2 & 16.01 \\
\hline Above Mill Creek & 42,500 & 12.9 & 0.06 & 17.2 & 45 & 59 & -41.8 & 70.8 & 91.6 & 27.39 \\
\hline Mill Creek & 46,000 & 14.0 & 0.48 & 10.2 & 33 & 42 & -31.8 & 75.7 & 90.0 & 8.29 \\
\hline Below Danville Road & 61,750 & 18.8 & 0.46 & 56.9 & 215 & 42 & 14.9 & 26.2 & 43.0 & 21.62 \\
\hline Vance Road & 107,500 & 32.7 & 15.02 & 37.6 & 82 & 34 & 3.6 & 9.6 & 44.8 & 2.34 \\
\hline
\end{tabular}

Analysis of streambed particle size sorting indicates the Middle Fork is receiving sediment from sources between the Above Coleman Creek study reach and the Talley Cemetery Road study reach, and from sources between the Talley Cemetery Road study reach, and the Above Mill Creek study reach. Examining the Middle Fork data (fig. 11) starting at Highway 7 and moving downstream through Baily Road, to Above Coleman Creek, the values for sorting decrease from 22.14 to 10.07 to 2.58 , respectively, indicating that the streambed material is becoming more sorted and suggesting that no new major sources of sediment are being introduced. Continuing downstream, the sorting values increase from 2.58 at Above Coleman Creek to 16.01 at Talley Cemetery Road to 27.39 at Above Mill Creek, suggesting less-sorted sediments have been introduced into the Middle Fork between Above Coleman Creek and Above Mill Creek. Coleman Creek (Sg $=6.63$ ) is one source, but the large sorting values at Talley Cemetery Road and Above Mill Creek suggest additional sediment sources are being input into the Middle Fork between the Above Coleman Creek site and the Above Mill Creek site.
Continuing downstream from the Above Mill Creek site to the Below Danville Road site, a moderate decrease in the sorting values from 27.39 to 21.62 , respectively, occurs. This moderate decrease in sorting between these two sites is because the Middle Fork is against Goosepond Mountain where talus has fallen into the river providing an additional sediment source. Continuing downstream from the Below Danville Road study site to the Vance Road site, the sorting values again decrease from 21.62 to 2.34 , respectively, again indicating that the streambed material is becoming more sorted and suggesting that no new major sources of sediment have been introduced into the Middle Fork between these two reaches.

\section{Sinuosity}

Sinuosity can range from straight $(\mathrm{K}<1.05)$, through partly meandering $(1.05<\mathrm{K}<1.5)$ to meandering $(\mathrm{K}>1.5)$ (Brice, 1964). All of the Middle Fork study reaches were classified as partially meandering except the Highway 7 reach, 
which classified as straight (table 8 ). The lower sinuosity value at the Highway 7 reach is the result of bedrock control at this point in the stream's flow path as it passes through a ridge of Arkansas Novaculite.

Between 1992 and 2002, the Above Mill Creek study reach's sinuosity remained the same, while the Vance Road study reach's sinuosity decreased slightly, and the sinuosity values for the remaining seven reaches increased slightly (table 8). This slight increase in sinuosity from 1992 to 2002 at seven of the nine study reaches indicates a slight decrease in stream slope has occurred at these reaches, which may be an adjustment to increased stream discharge, decreased sediment discharge, decreased sediment size, or some combination of these factors.

The 2002 sinuosity values reported in table 8 were used when classifying stream reach types (discussed in the next section). The sinuosity values for all the study sites, except at the Above Mill Creek and Mill Creek, were slightly lower than their stream type classification would indicate; although they easily fall within the +/- 0.2 units, Rosgen (1994) allows sinuosity values to vary when classifying streams. Sinuosity can be modified by bedrock control, roads, channel confinement, and vegetation and carries the least weight of all the criteria used to determine stream type classification.

\section{Stream Reach Classification}

The Middle Fork changes from a moderately entrenched, riffle dominated channel in the upstream reaches to a slightly entrenched, riffle/pool channel in the downstream reaches. Of the nine study reaches examined within the Middle Fork basin, the two upstream reaches, Highway 7 and Baily Road reaches, classified as $\mathrm{B} 4 \mathrm{c}_{/ 1}$ stream type, while the seven downstream reaches classified as $\mathrm{C}_{/ 1}$ stream type under the Rosgen (1994) stream reach classification system. The "c" designation indicates that the stream classified as a B with a less than 2 percent slope. The "/1" designates the presence of bedrock within the study reach. The change in stream type is characteristic of most streams with increasing distance down valley. Within a stream's headwaters the valleys are narrow, the slopes are steep, and the bed material relatively large. As the stream flows down the valley, the slope flattens, the valley becomes wider, and the bed material becomes finer (Schumm, 1977).

The two upstream study reaches, at Highway 7 and Baily Road, are moderately entrenched, riffle dominated channels, with moderate width/depth ratios, sinuosities of 1.02 and 1.13, respectively, and slopes of 0.0037 and 0.0078 , respectively. The sinuosity values are low for B4 stream types because of the influence of bedrock at these sites limiting the stream's ability to meander. The Middle Fork at these locations has developed within a relatively narrow, gently sloping, colluvial valley with bedrock structural control. The channel bed morphology is sand and gravel dominated with lesser amounts of cobble and is characterized by a series of rapids over cobble and bedrock with irregular spaced scour pools. The stream banks are well vegetated consisting of unconsolidated, heterogeneous, non-cohesive, alluvial materials that are finer than the bed materials.

The remaining seven study reaches are slightly entrenched, gravel-dominated meandering, riffle/pool channels with well developed flood plains. Width/depth ratios are moderate to high, ranging from 27, at the Talley Cemetery Road site, to 89, at the Below Danville Road site. Sinuosity values are low to moderate, ranging from 1.09, at the Coleman Creek and Talley Cemetery Road sites, to 1.38, at the Above

Table 8. Changes in sinuosity from 1992 to 2002.

\begin{tabular}{|c|c|c|c|c|c|c|c|}
\hline Study reach & $\begin{array}{c}1992 \text { stream } \\
\text { length } \\
\text { (feet) }\end{array}$ & $\begin{array}{c}2002 \text { stream } \\
\text { length } \\
\text { (feet) }\end{array}$ & $\begin{array}{c}\text { Valley length } \\
\text { (feet) }\end{array}$ & $\begin{array}{c}1992 \\
\text { sinuosity }\end{array}$ & $\begin{array}{c}2002 \\
\text { sinuosity }\end{array}$ & $\begin{array}{l}\text { Change in } \\
\text { sinuosity from } \\
1992 \text { to } 2002\end{array}$ & $\begin{array}{l}\text { Reach sinuosity } \\
\text { description }\end{array}$ \\
\hline Highway 7 & 1,791 & 1,799 & 1,771 & 1.01 & 1.02 & 0.01 & Straight \\
\hline Baily Road & 3,048 & 3,124 & 2,760 & 1.10 & 1.13 & 0.03 & Partially meandering \\
\hline Above Coleman Creek & 4,813 & 4,851 & 3,527 & 1.36 & 1.38 & 0.02 & Partially meandering \\
\hline Coleman Creek & 2,704 & 2,722 & 2,496 & 1.08 & 1.09 & 0.01 & Partially meandering \\
\hline Talley Cemetery Road & 2,608 & 2,704 & 2,479 & 1.05 & 1.09 & 0.04 & Partially meandering \\
\hline Above Mill Creek & 4,469 & 4,470 & 3,483 & 1.28 & 1.28 & 0.00 & Partially meandering \\
\hline Mill Creek & 912 & 1,011 & 835 & 1.09 & 1.21 & 0.12 & Partially meandering \\
\hline Below Danville Road & 7,176 & 7,236 & 6,066 & 1.18 & 1.19 & 0.01 & Partially meandering \\
\hline Vance Road & 6,802 & 6,745 & 5,999 & 1.13 & 1.12 & -0.01 & Partially meandering \\
\hline
\end{tabular}


Coleman Creek site. The sinuosity values at four of the seven sites (Coleman Creek, Talley Cemetery Road, Below Danville Road, and Vance Road) are low for C4 stream types because the steam at these locations is against the valley wall and the influence of bedrock at these sites is limiting the streams ability to meander. The Middle Fork at these lower seven locations has developed within a relatively broad, gently sloping, coarse alluvial valley with bedrock structural control. The channel bed morphology is gravel dominated with lesser amounts of sand and cobble and is characterized by riffle/pool sequences. The stream banks are generally well vegetated consisting of unconsolidated, heterogeneous, non-cohesive, alluvial materials that are finer than the bed materials. The reaches are characterized by the presence of point bars and other depositional features, and are susceptible to lateral shifts in stability caused by direct channel disturbances and changes in the flow and sediment regimes.

It should be noted that bedrock was observed at all nine sampling sites. The importance of the presence of bedrock is that it limits vertical movement of the stream, thus potentially increasing the lateral adjustments made by the stream when the stream system is disturbed. Bedrock also can provide a hydraulically smooth surface (low Manning's roughness coefficient) producing greater velocities and greater shear stresses that can mobilize greater quantities of sediment and larger sizes of sediment.

\section{Implications}

Streams have inherent dynamic qualities by which change continually occurs in the stream position and shape. Change may be slow or rapid, but all streams are subjected to forces that cause changes to occur. The degree of stream channel change varies with the hydrologic events, bed and bank materials, type and extent of vegetation on the banks, and floodplain use. Stable stream channels maintain their width, depth, and slope (sinuosity) over time while transporting the water and sediment produced within their basin without excessive erosion or deposition.

With the increasing anthropogenic activity taking place in the Middle Fork Basin, changes in the hydrologic regime are to be expected. Over the past 30 years, the Middle Fork Basin has experienced a marked increase in urbanization and associated infrastructure. These activities tend to reduce infiltration and produce greater runoff in shorter amounts of time, hence, increasing the magnitude of peak flows and reducing the time between storm events and the peak flows. Concurrently, a number of dams and weirs have been constructed within the basin. These structures tend to trap water and sediment, and, hence, attenuate peak flows.

Hydraulic geometry dimensions measured at nine study reach sites reflect the Middle Fork's response to the changes in its hydrologic regime. When compared to the Ouachita Mountains regional hydraulic geometry curves, five of the nine sites have smaller cross-sectional areas, greater top widths, and shallower mean depths than the regional curves predicted for these study reach sites. These differences in hydraulic geometry dimensions are the result of some combination of the following changes in the stream's hydrologic regime: (1) decreased streamflow, (2) increased sediment size, or (3) increased sediment flow. One study reach site, Talley Cemetery Road, matches the dimensions predicted by the Ouachita Mountains regional hydraulic geometry curves, indicating that the site is in equilibrium with the current hydrologic flow regime. The other three study reach sites have structural influences upstream making a comparison to the Ouachita Mountains regional curves tenuous.

An evaluation of shear stresses on the streambed from discharge measurements made at the two USGS gaging stations within the study basin confirm the evaluation of the study reach sites made using the Ouachita Mountains regional hydraulic geometry curves. Shear stress analysis of discharge measurements made at the Talley Cemetery Road study reach (USGS gaging station 07362641) indicate that the stream at this location is in equilibrium with the current hydrologic flow regime. Shear stress analysis of discharge measurements made at the Vance Road study reach (USGS gaging station 07362693), one of the five sites the regional curves indicated to have small cross-sectional areas, large top widths, and shallow mean depths, indicate that the stream at this location is overly wide and shallow, and is not in equilibrium with the current flow regime.

Because historical flow or hydraulic geometry records for the Middle Fork do not exist, an analysis of changes in the stream sinuosity (a surrogate for slope) was conducted using 1992 and 2002 aerial photography. The sinuosity analysis indicated that the Middle Fork has experienced a very slight increase in sinuosity over the decade. This slight increase in sinuosity corresponds to a slight decrease in stream slope suggesting the Middle Fork has experienced some combination of: (1) an increase in streamflow, (2) a decrease in sediment flow, or (3) a decrease in sediment size over the decade.

However, because the changes in sinuosity were so slight, well within possible measurement errors, this assessment should be viewed cautiously.

The analysis of sinuosity appears to contradict the analysis of the Middle Fork's hydraulic geometry, but, whereas the hydraulic geometry analysis was for a single point in time, the sinuosity analysis was for change over a decade of time. If the tenuous assessment of sinuosity is correct, together these analyses suggest that although the Middle Fork is currently (2003) overly wide and shallow it may be slowly trending towards a more stable hydraulic geometry.

Streambed particle samples were examined to evaluate the streambed sediment portion of the flow regime and to help identify non-point sediment source locations. An analysis of the median (D50) particle size measured and the particle sizes transported during bankfull flow events based on tractive force calculations indicate that most of the streambed particles within the Middle Fork are in motion during bankfull flow 
events, which is typical of Ouachita Mountain streams. Analysis of streambed particle size sorting indicates the Middle Fork is receiving substantial amounts of sediment from sources between the Above Coleman Creek and the Talley Cemetery Road study reaches and from between the Talley Cemetery Road and the Above Mill Creek study reaches. The reliability of the sediment source characterization is tenuous because of the variability in streambed sediment, but is included to assist in the prioritization of possible-restoration efforts. Typical transport mechanisms of sediment into a river system include sheet and rill erosion from upland areas, streambed degradation of tributaries joining the river, gully erosion, flood-plain scour, streambed degradation of the main stem, and streambank erosion and failure.

The topographic, geologic, and physical characteristics of the Middle Fork Basin are major influences on how the stream is responding to the changes in its hydrologic regime. The upper two study reaches are classified as Rosgen B4 stream types. They are gravel dominated channels with lesser amounts of boulders, cobbles, and sand and are characterized by a series of riffles with irregular spaced scour pools. The B4 stream type is considered relatively stable and is not a high sediment supply stream channel. The remaining seven study reaches are classified as Rosgen $\mathrm{C} 4$ stream types. They are gravel-dominated, riffle/pool channels with well developed flood plains. The streambanks are composed of unconsolidated, heterogeneous, non-cohesive, alluvial materials that are finer than the gravel-dominated streambeds. Consequently, the $\mathrm{C} 4$ stream type is susceptible to accelerated lateral/bank erosion. Rates of lateral adjustment are influenced by the presence and condition of riparian vegetation. Sediment supply is moderate to high. The $\mathrm{C} 4$ stream type is very susceptible to shifts in both lateral and vertical stability caused by direct channel disturbances or changes in the flow and sediment regimes of the contributing basin. Together the characteristics of these two stream types indicate that the lower reaches of the Middle Fork are more susceptible to erosion and bank failure than the upper reaches. Additionally, bedrock was noted at all nine study reach sites. The importance of the presence of bedrock is twofold. First, bedrock prevents the stream from making vertical adjustments in its streambed and hence prevents head-cuts from migrating up the system, initiating further instability. Second, because bedrock is preventing the stream from making vertical adjustments in its streambed, the stream is limited to lateral adjustments, making the streambanks more susceptible to lateral/bank erosion. This indicates that maintaining a continuous, high-quality, vegetated riparian corridor is even more important for the Middle Fork than for other similar streams that do not have the bedrock control.

Distinguishing the effects on a river basin from one type of disturbance from the effects of another type of disturbance is difficult, and practically impossible with a one-time study such as described in this report. To begin quantifying cause and effect of disturbances to a hydrologic system, at a minimum, long-term flow, long-term climate, changes in land-use data and multiple years of hydraulic geometry measurements are needed.

\section{Summary}

This report summarizes the Middle Fork's current (2002-2003) channel geometry characteristics for nine study reaches in the upper $91 \mathrm{mi}^{2}$ of the watershed. Assessments at each study reach included comparisons of measured stream geometry dimensions (cross-sectional area, top width, and mean depth) at bankfull stage to preliminary regional hydraulic geometry curves for the Ouachita Mountains Physiographic Province of Arkansas and Oklahoma, evaluations of streambed materials, comparison of stream reach sinuosity from 1992 and 2002, and classification of individual stream reach types using the Rosgen stream reach classification system.

When compared to the Ouachita Mountains regional hydraulic geometry curves, the Talley Cemetery Road reach closely matches the hydraulic geometry curve values indicating that the reach is in equilibrium with respect to streamflow and sediment discharges. The Mill Creek reach hydraulic geometry data have the greatest divergence from the Ouachita Mountains regional hydraulic geometry curves, indicating that Mill Creek may still be in the process of transitioning from an uncontrolled, total watershed drainage area of $10.0 \mathrm{mi}^{2}$ to a new uncontrolled basin drainage area of $0.9 \mathrm{mi}^{2}$.

The Highway 7 and the Above Mill Creek reaches both have bankfull cross-sectional area, top width, and mean depth values considerably smaller than what the Ouachita Mountains regional hydraulic geometry curves predict. Both reaches have structural influences upstream that may be reducing the hydraulic geometry; a ridge of Arkansas Novaculite is pinching the valley width above the Highway 7 reach, and water is being withdrawn at a low-water weir upstream from the Above Mill Creek site. This does not mean the reaches are unstable, only that the reach conditions differ from conditions used in the development of the Ouachita Mountains hydraulic geometry regional curves.

The five remaining Middle Fork study reaches have cross-sectional areas slightly smaller than, top widths greater than, and mean depths shallower than the Ouachita Mountains hydraulic geometry regional curves predict for watersheds with their respective drainage areas. The Middle Fork, at these locations, is wider and shallower than what the regional hydraulic geometry curves indicate for natural, stable Ouachita Mountains' streams. This suggests that the Middle Fork is receiving and transporting more streambed sediment, or larger streambed sediment, or decreased streamflow discharge, or some combination of the three.

Streambed-material analysis indicates that the Middle Fork is a bedrock influenced, gravel dominated stream with lesser amounts of sand and cobbles. Tractive force analysis indicates that a majority of the streambed particle sizes are in motion during bankfull flow events at six of the nine study 
reaches. At the remaining three stream reaches (Coleman Creek, Below Danville Road, and Vance Road), the tractive force values were less than the measured median streambed sediment sizes $\left(\mathrm{D}_{50}\right)$ indicating that less than 50 percent of the streambed particles are subject to movement during bankfull flow events.

Analysis of the particle size sorting indicates that no new sediment sources are being introduced into the Middle Fork between the Highway 7 and Above Coleman Creek study reaches. Sediment is being introduced into the Middle Fork between each of the study reaches between the Above Coleman Creek and Above Mill Creek Reaches. No new sediment sources are being introduced into the Middle Fork between the Below Danville Road and Vance Road study reaches.

At the Highway 7 study reach the sinuosity classified as straight, while at the remaining study reaches the sinuosities were classified as partially meandering. Examining the change in sinuosity from 1992 to 2002, the sinuosity values for seven of the nine study reaches increased slightly, while the Above Mill Creek study reach's sinuosity remained unchanged, and the Vance Road study reach's sinuosity decreased slightly. This indicates that the Middle Fork is slowly trending towards a geometry more closely matching the geometry predicted by the Ouachita Mountains regional hydraulic geometry curves. Because changes in sinuosity were so slight, this analysis should be viewed judiciously

The two upstream study reaches, at Highway 7 and Baily Road, classify as B4c $c_{11}$ stream types. The reaches are moderately entrenched, riffle dominated channels. The channels have developed in narrow, gently sloping valleys on colluvial deposits with bedrock structural control. Channel materials are composed primarily of gravel with lesser amounts of boulders, cobbles, and sand. The "c" designation indicates that the stream classified as a B stream type with a less than 2 percent slope. The " " designation indicates the presence of bedrock within the stream reach channel.

The remaining seven study reaches classify as $\mathrm{C} 4 / 1$ stream type. These reaches are slightly entrenched, meandering, gravel-dominated, riffle/pool channels with well developed flood plains. The streambanks generally are composed of unconsolidated, heterogeneous, non-cohesive, alluvial materials that are finer than the gravel-dominated bed material. Consequently, the streams are susceptible to bank erosion. Rates of lateral adjustment are influenced by the presence and condition of riparian vegetation. Sediment supply is moderate to high. The reaches are characterized by the presence of point bars and other depositional features, and are susceptible to lateral shifts in stability caused by direct channel disturbance and changes in the flow and sediment regimes. The " " designation indicates the presence of bedrock within the stream reach channel.

Distinguishing the effects on a river basin from one type of disturbance from the effects of another type of disturbance is difficult, and practically impossible with a one-time study described in this report. To begin quantifying cause and effect of disturbances to a hydrologic system, at a minimum, long-term flow, long-term climate, changes in land-use data and multiple years of hydraulic geometry measurements are needed.

\section{Selected References}

Annable, W.K., 1994, Morphological relations of rural water courses in southeastern Ontario for use in natural channel design: Masters Thesis, University Of Guelph, School of Engineering, Guelph, Ontario, Canada.

Arkansas Geological Commission, 2000a, Geologic History of Arkansas: a Summary, accessed September 2003 at URL http://www.state.ar.us/agc/geohisto.htm.

Arkansas Geological Commission, 2000b, Stratigraphic Summary of the Arkansas Valley and Ouachita Mountains, accessed September 2003 at URL http://www.state.ar.us/ agc/arvalley.htm.

Arkansas Historic Preservation Program, no date, Ethnic variation and vernacular architecture in the farm-steads of the Ozark-St. Francis and Ouachita National Forest. Hot Springs, Arkansas: Arkansas Historic Preservation Program, $88 \mathrm{p}$.

Brice, J.C., 1964, Channel patterns and terraces of the Loup Rivers in Nebraska: U.S. Geological Survey Professional Paper 422-D, 35 p.

Chow, V.T., Maidment, D.R., and Mays, L.W., 1988, Applied Hydrology: New York, McGraw-Hill Book Company Inc., 572 p.

Dunne, T. and Leopold, L.B., 1978, Water in Environmental Planning: San Francisco, California, W.H. Freeman and Co., 818 p.

Etchieson, G.M., Erickson, E., Pfeiffer, M.A., Coleman, R.E., Haikey, L.D., Pell, W.F., and Nolan, D.J., Jr., 1999, Archeological and Historical Background in Ozark-Ouachita Highlands Assessment - social and economic conditions: General Technical Report SRS-34, Asheville, North Carolina: U.S. Department of Agriculture, Forest Service, Southern Research Station, 299 p.

Fenneman, N.M., 1938, Physiography of the eastern United States: New York, McGraw-Hill Book Co., Inc., 689 p.

Haley, B.R, Glick, E.E., Bush, W.V., Clardy, B.F., Stone, C.G., Woodward, M.B., Zachry, D.L., 1976, Geologic map of Arkansas: U.S. Geological Survey, scale 1:500,000.

Hot Springs Village Property Owner's Association, 2003, Hot Springs Village Information, accessed on September 24, 2003 at URL: http://www.hotspringsvillageinfo.com/.

Lane, E.W., 1955, Design of stable channels: American Society of Civil Engineers Transactions, 120, p. 1234-1279. 
Leopold, L.B., 1994, A view of the river: Cambridge, Ma., Harvard University Press, 298 p.

Leopold, L.B., and Maddock, T. 1953, The hydraulic geometry of stream channels and some physiographic implications: U.S. Geological Survey Professional Paper 252, 57 p.

Leopold, L.B., Wolman, M.G., and Miller, J.P., 1964, Fluvial Processes in Geomorphology: San Francisco, California, Freeman, 522 p.

Newbury, R.W., and Gaboury, M.N., 1993, Stream analysis and fish habitat design-A field manual: British Columbia, Canada, Newbury Hydraulics Ltd., Gibsons, 262 p.

Plebuch, R.O., and Hines, M.S., 1967, Water resources of Pulaski and Saline Counties, Arkansas: U.S. Geological Survey Water-Supply Paper 1839-B, 25 p.

Rosgen, D.L., 1994, A classification of natural rivers: Catena, v. 22, issue 3, p. 169-199.

Rosgen, D.L. and H.L. Silvey, 1996, Applied River Morphology: Pagosa Springs, Colorado, Wildland Hydrology Books, $390 \mathrm{p}$.

Schumm, S.A., and Lichty, R.W., 1963, Channel widening and flood plain construction along Cimarron River in southwestern Kansas: U.S. Geological Survey Professional Paper 352-D, p. 71-88.

Schumm, S.A., 1977, The fluvial System: New York, John Wiley and Sons, 338 p.

Sizer, M.K., Longstreth, M., and Moon, Z.K., 1999, Social and Demographic Conditions and Trends in Ozark-Ouachita Highlands Assessment - social and economic conditions: General Technical Report SRS-34, Asheville, North Carolina: U.S. Department of Agriculture, Forest Service, Southern Research Station, 299 p.

University of Virginia Geospatial and Statistical Data Center, United States Historical Census Data Browser, 1998, accessed August 21, 2003 at URL: http://fisher.lib.virginia. edu/census.

U.S. Department of Agriculture, Forest Service, no date, Land acquisition records: unpublished records on file at the Forest Supervisors' office, U.S. Department of Agriculture, Forest Service, Ouachita National Forest, Hot Springs, Arkansas, various pagination.

Vanoni, V.A., ed., 1975, Sedimentation Engineering: New York, N.Y., American Society of Civil Engineers, ASCE Manuals and Reports on Engineering Practice-No. 54, 745

p.

Wolman, M.G., 1954, A method of sampling coarse river-bed material: Transactions of American Geophysical Union 35, p. 951-956.
Wolman, M.G., and Miller, R., 1978, Magnitude and frequency of forces in geomorphic processes: Journal of Geology, v. 68, p. 54-74.

Yanchosek, John J. and Hines, Marion S., 1979, Drainage areas of streams in Arkansas, Ouachita River Basin: U.S. Geological Survey Open-File Report 80-334, 87 p. 

Appendixes 1-9 


\section{APPENDIX 1: Highway 7}

\section{Drainage Area: $13.2 \mathrm{mi}^{2}$}

\section{LOCATION}

Reach: Arkansas State Highway 7 Bridge

Section: W1/2 Sect.20

County: Garland

Quadrangle map: Jessieville

Township: 1 North

Range: 19 West

\section{BANKFULL CHARACTERISTICS (values averaged from cross sections 5 and $\mathbf{6}$ )}

Stage: $3.0 \mathrm{ft}$ above thalweg

Cross-sectional area: $112.2 \mathrm{ft}^{2}$

Top width: $61.4 \mathrm{ft}$

Mean depth: $1.8 \mathrm{ft}$

Hydraulic radius: $1.8 \mathrm{ft}$
Slope: $0.0037 \mathrm{ft} / \mathrm{ft}$

Tractive force: $0.42 \mathrm{lbf} / \mathrm{ft}^{2}$

Particle size transported: $21 \mathrm{~mm}$

Portion of bed material transported: 60.1 percent

\section{STREAM CLASSIFICATION (values averaged from cross sections 5 and 6 )}

Flood prone width: $123 \mathrm{ft}$

Entrenchment ratio: 2.0

Stream type: $\mathrm{B} 4 \mathrm{c}_{/ 1}$
Width to depth ratio: 34

Sinuosity: 1.02

\section{LOCATION AERIAL PHOTOGRAPH - MAP}

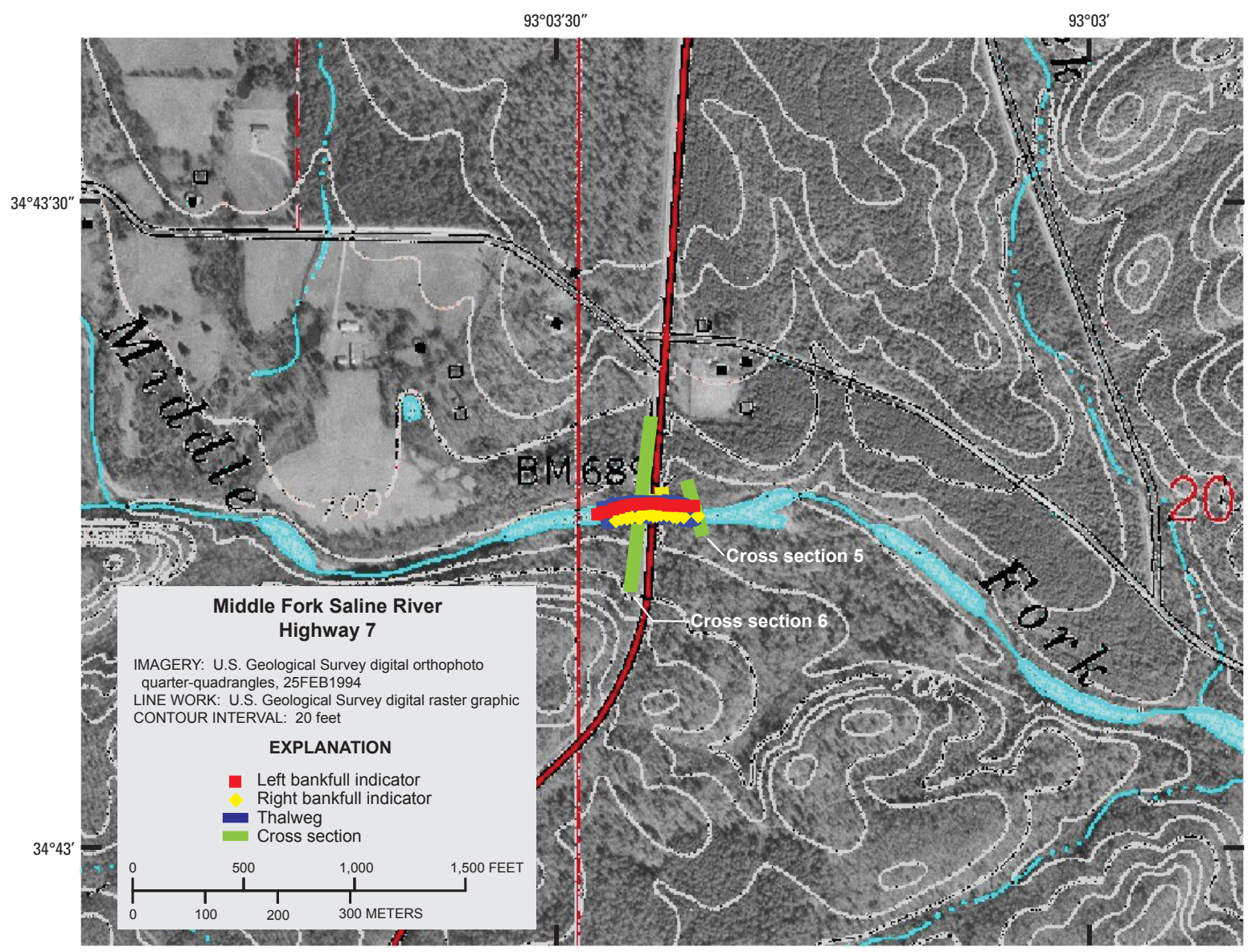




\section{SITE SURVEY DATA PLOTS}
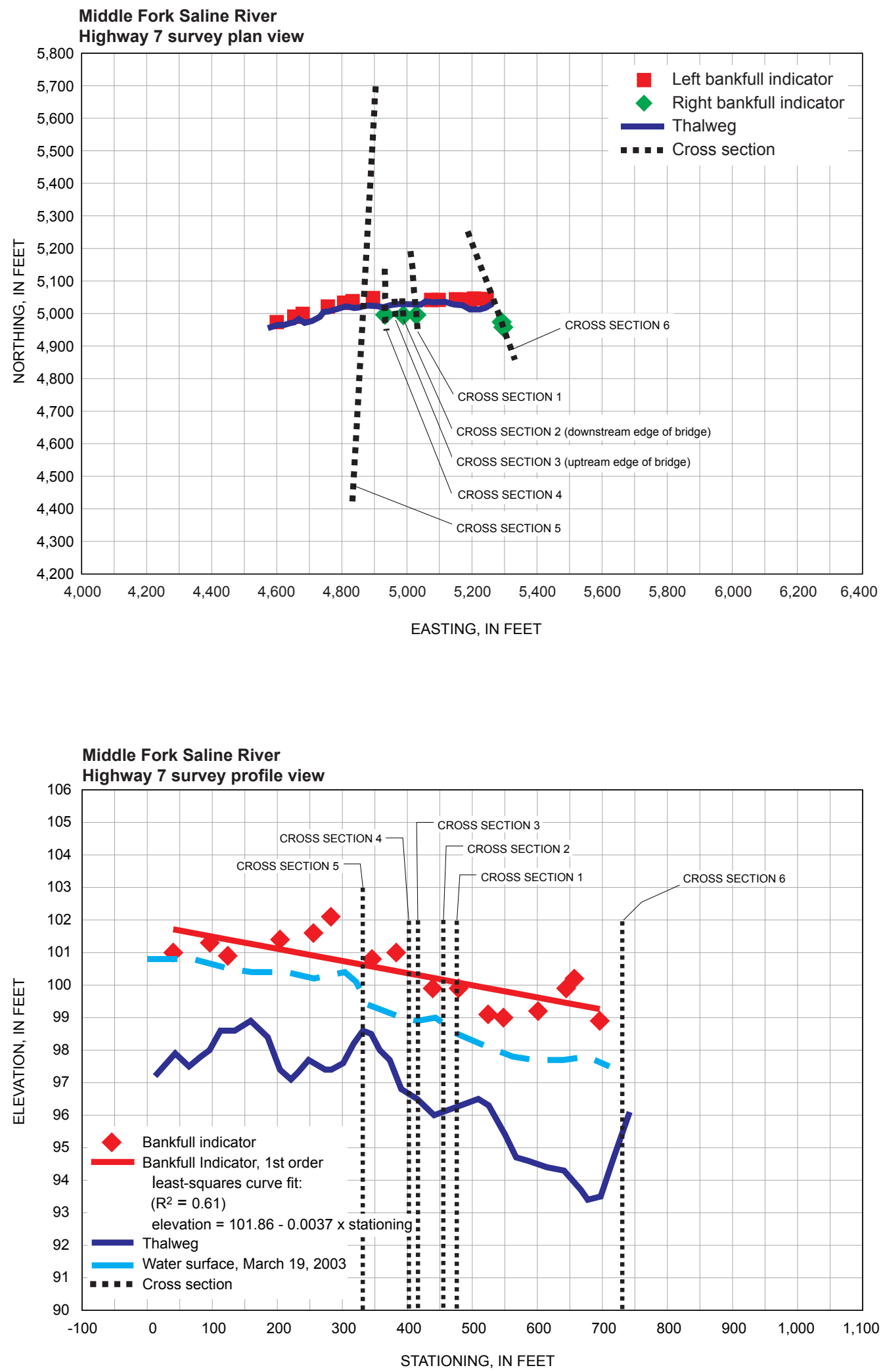


\section{APPENDIX 1: Highway 7}

\section{Drainage Area: $13.2 \mathrm{mi}^{2}$}

\section{SITE SURVEY DATA PLOTS}
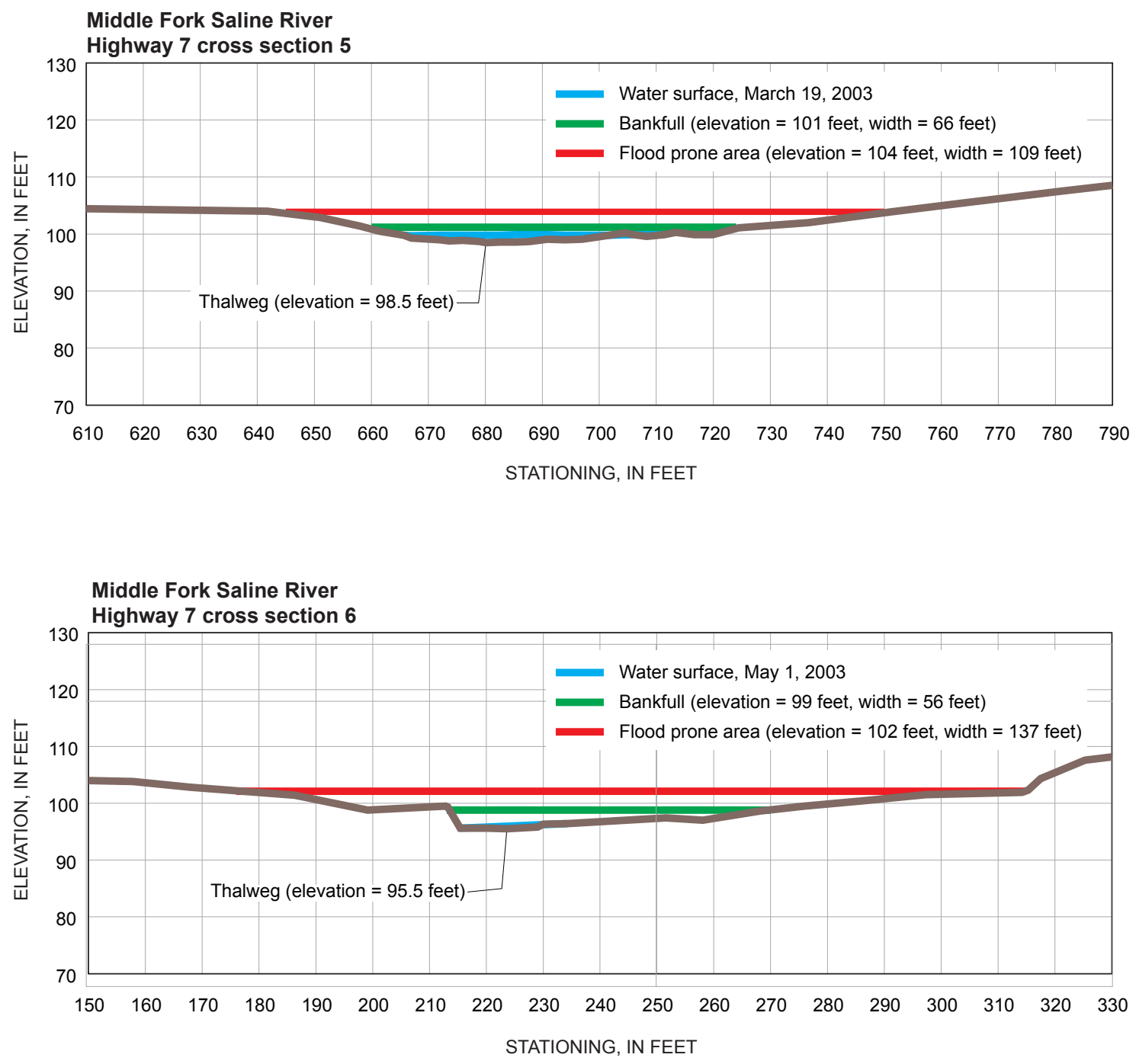


\section{SITE SURVEY DATA PLOTS}

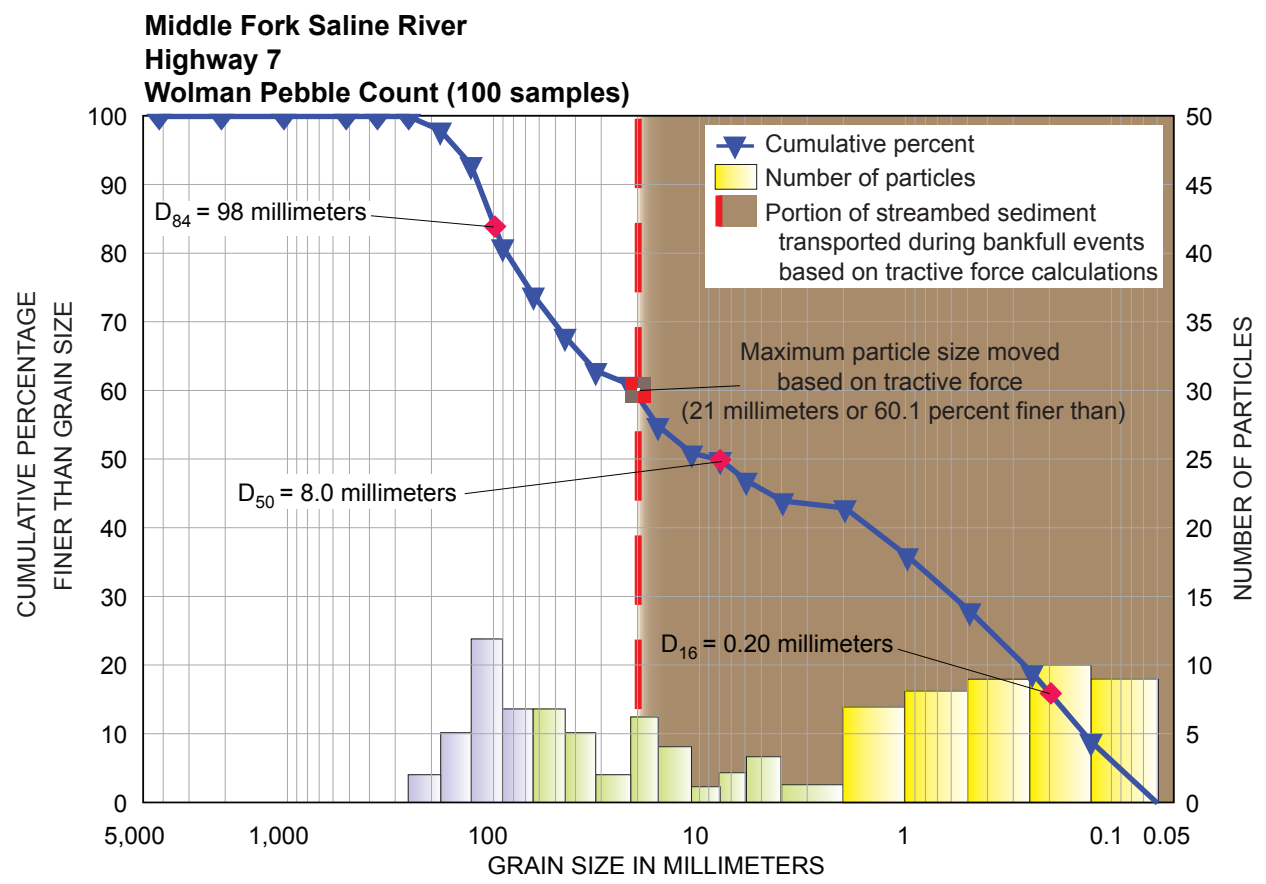

Percent (\%) by particle type based on total count (100):

\begin{tabular}{c|c|c|c|c|l}
\hline $\begin{array}{l}\text { Bed- } \\
\text { rock }\end{array}$ & Boulder & Cobble & Gravel & Sand & Silt or \\
& & $26 \%$ & $31 \%$ & $43 \%$ & Clay \\
\hline
\end{tabular}




\section{APPENDIX 1: Highway 7}

\section{SITE SURVEY DATA PLOTS}

Middle Fork Saline River

Highway 7 cross section 5, May 1, 2003
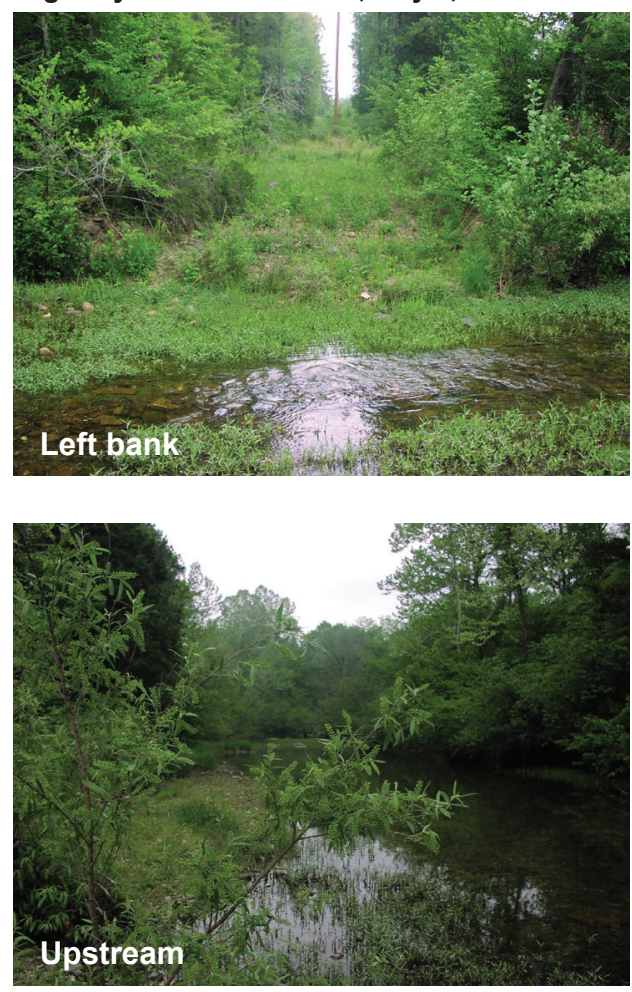

Middle Fork Saline River

Highway 7 cross section 6, May 1, 2003
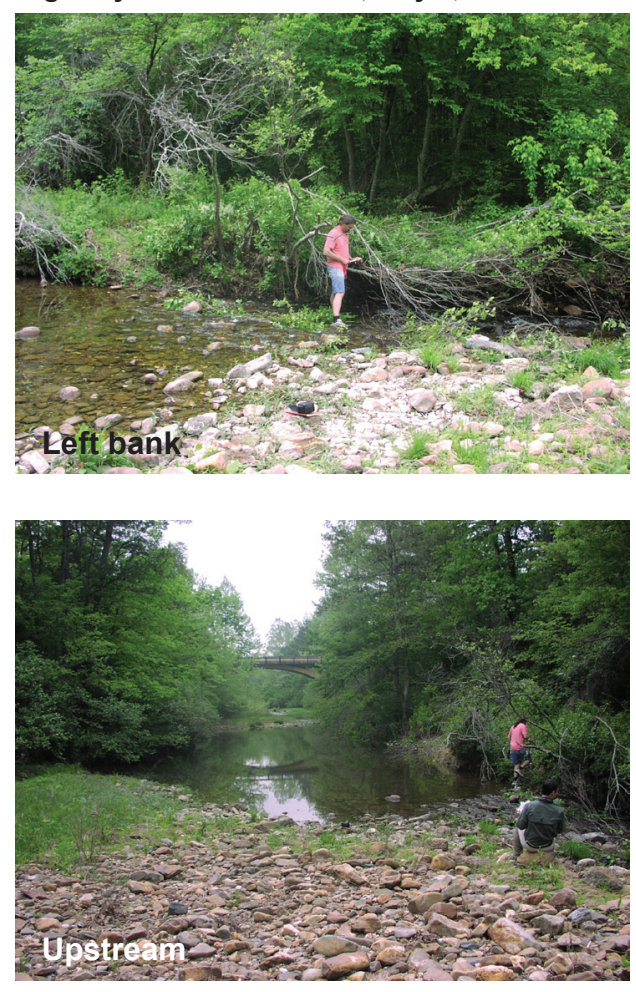

\section{Drainage Area: $13.2 \mathrm{mi}^{2}$}
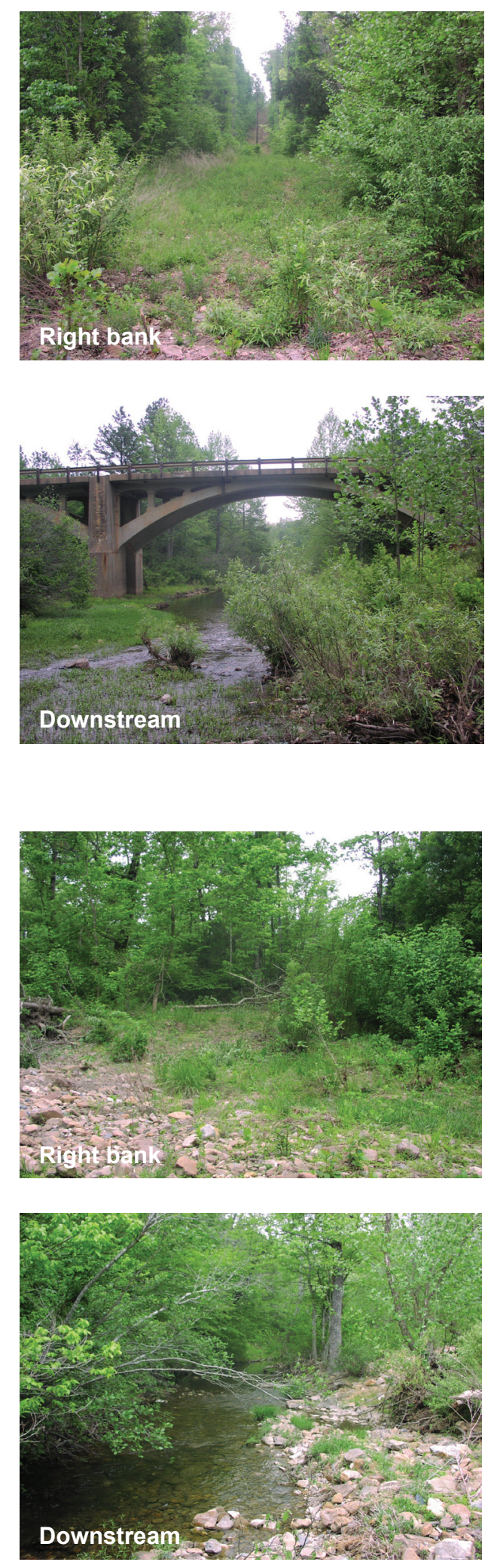


\section{APPENDIX 2: Baily Road}

\section{LOCATION}

Reach: $900 \mathrm{ft}$ above Baily Road Bridge

County: Garland

Quadrangle map: Jessieville

\section{Drainage Area: $15.5 \mathrm{mi}^{2}$}

\section{BANKFULL CHARACTERISTICS (values averaged from cross sections 1 and 2)}

Stage: $5.1 \mathrm{ft}$ above thalweg

Cross-sectional area: $243.8 \mathrm{ft}^{2}$

Top width: $102.4 \mathrm{ft}$

Mean depth: $2.4 \mathrm{ft}$

Hydraulic radius: $2.6 \mathrm{ft}$
Slope: $0.0078 \mathrm{ft} / \mathrm{ft}$

Tractive force: $1.27 \mathrm{lbf} / \mathrm{ft}^{2}$

Particle size transported: $64 \mathrm{~mm}$

Portion of bed material transported: 82.9 percent

\section{STREAM CLASSIFICATION (values averaged from cross sections 1 and 2)}

Flood prone width: $211 \mathrm{ft}$

Entrenchment ratio: 2.1

Stream type: $\mathrm{B} 4 \mathrm{c}_{/ 1}$
Width to depth ratio: 43

Sinuosity: 1.13

\section{LOCATION AERIAL PHOTOGRAPH - MAP}

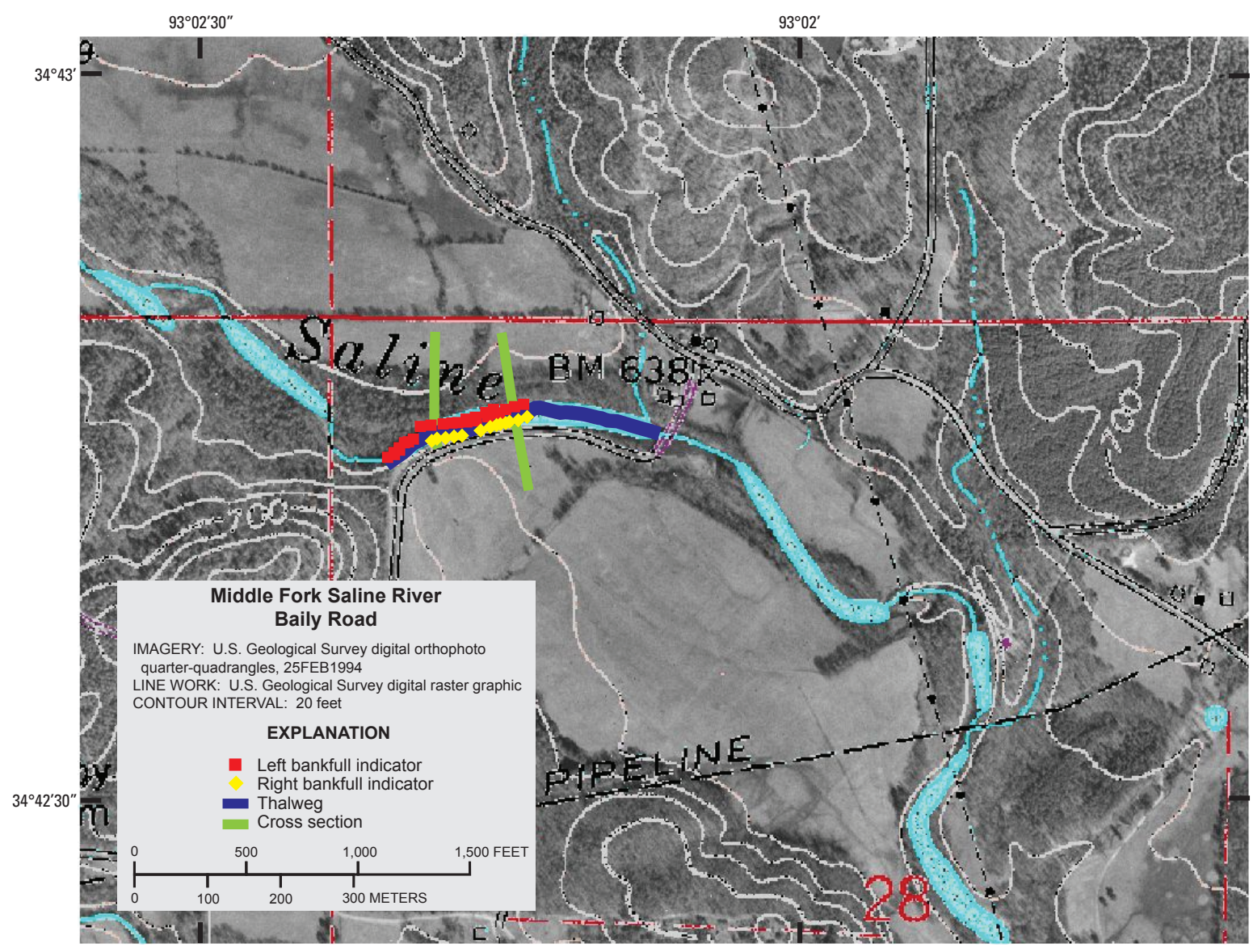




\section{APPENDIX 2: Baily Road}

\section{Drainage Area: $15.5 \mathrm{mi}^{2}$}

\section{SITE SURVEY DATA PLOTS}
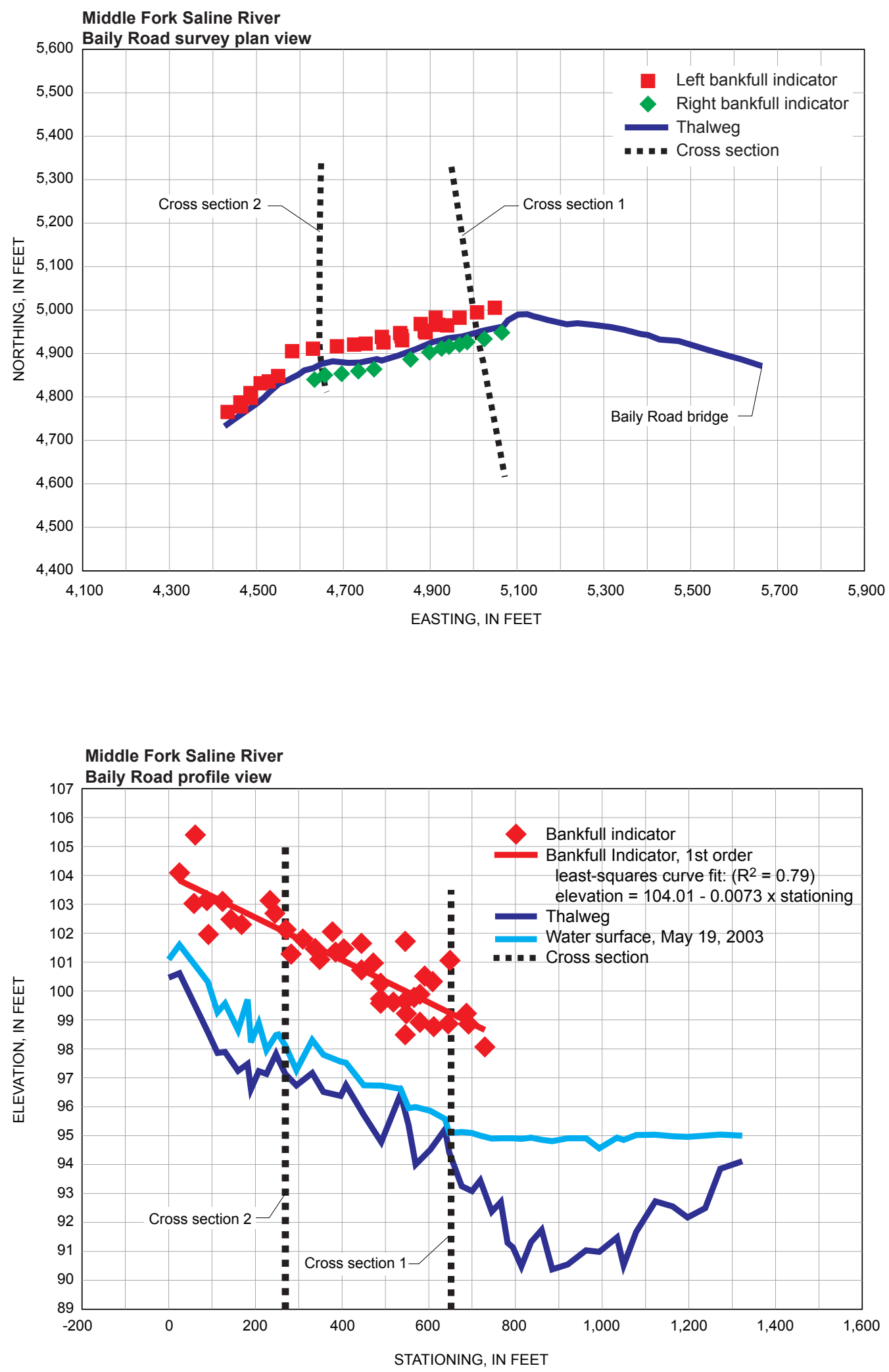


\section{APPENDIX 2: Baily Road}

\section{Drainage Area: $15.5 \mathrm{mi}^{2}$}

\section{SITE SURVEY DATA PLOTS}
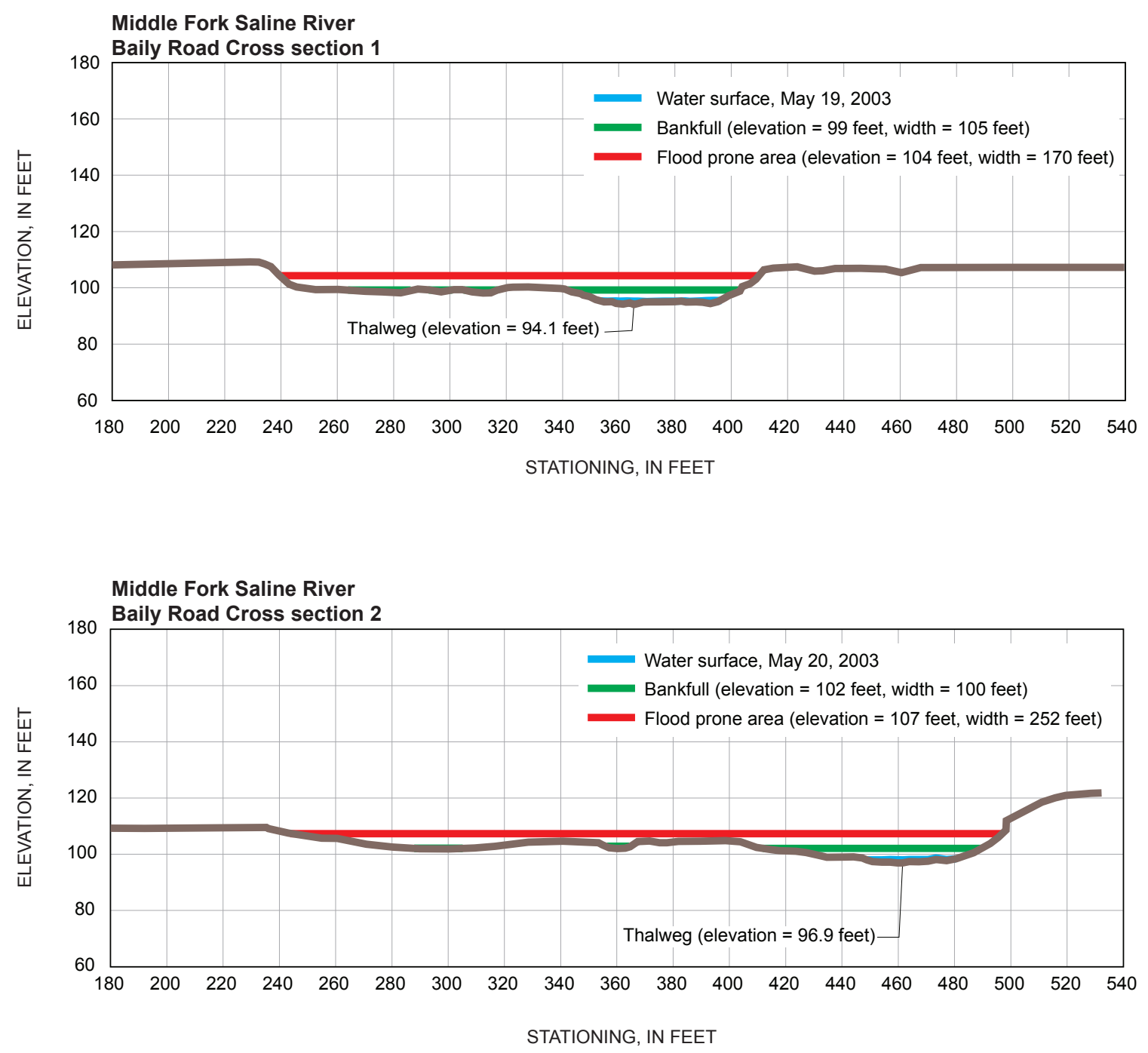


\section{APPENDIX 2: Baily Road}

\section{Drainage Area: $15.5 \mathrm{mi}^{2}$}

\section{SITE SURVEY DATA PLOTS}

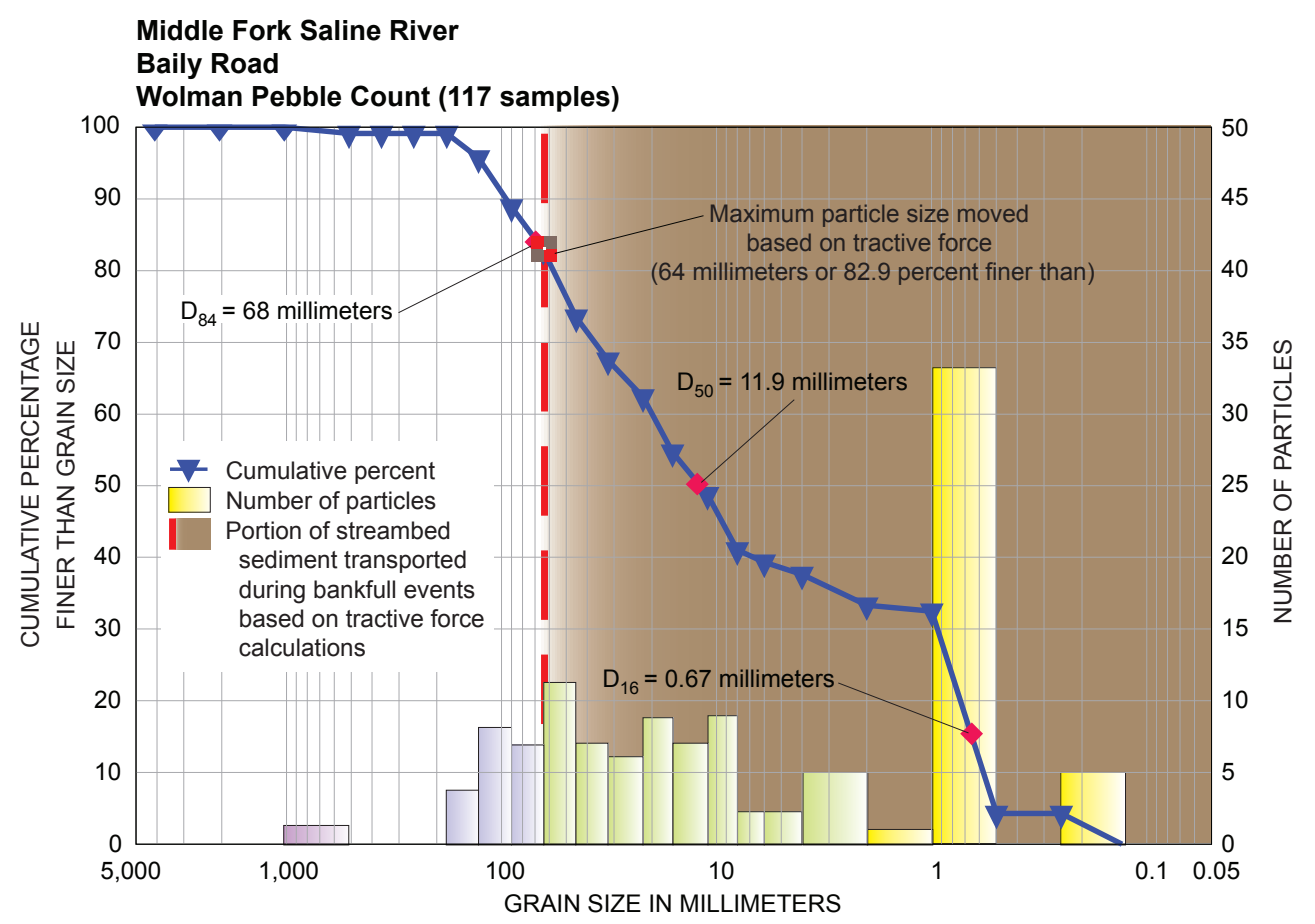

Percent (\%) by particle type based on total count (200):

\begin{tabular}{c|c|c|c|c|l}
\hline Bedrock & Boulder & Cobble & Gravel & Sand & Silt or \\
$41 \%$ & $1 \%$ & $10 \%$ & $29 \%$ & $19 \%$ & Clay \\
\hline
\end{tabular}




\section{APPENDIX 2: Baily Road}

Drainage Area: $15.5 \mathrm{mi}^{2}$

\section{PHOTOGRAPHS OF CROSS SECTIONS}

Middle Fork Saline River

Baily Road upstream cross section, September 9, 2003
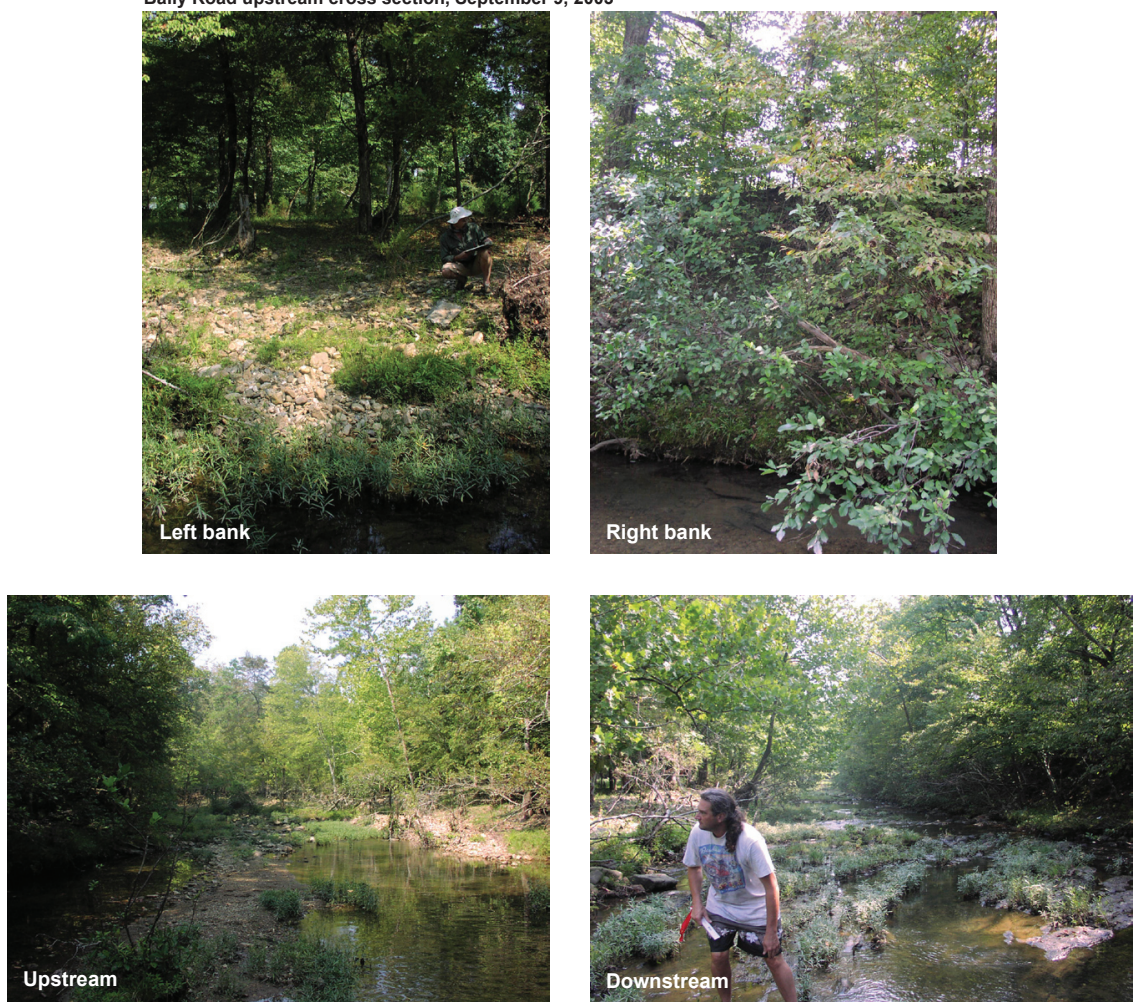

Middle Fork Saline River

Baily Road downstream cross section, September 9, 2003
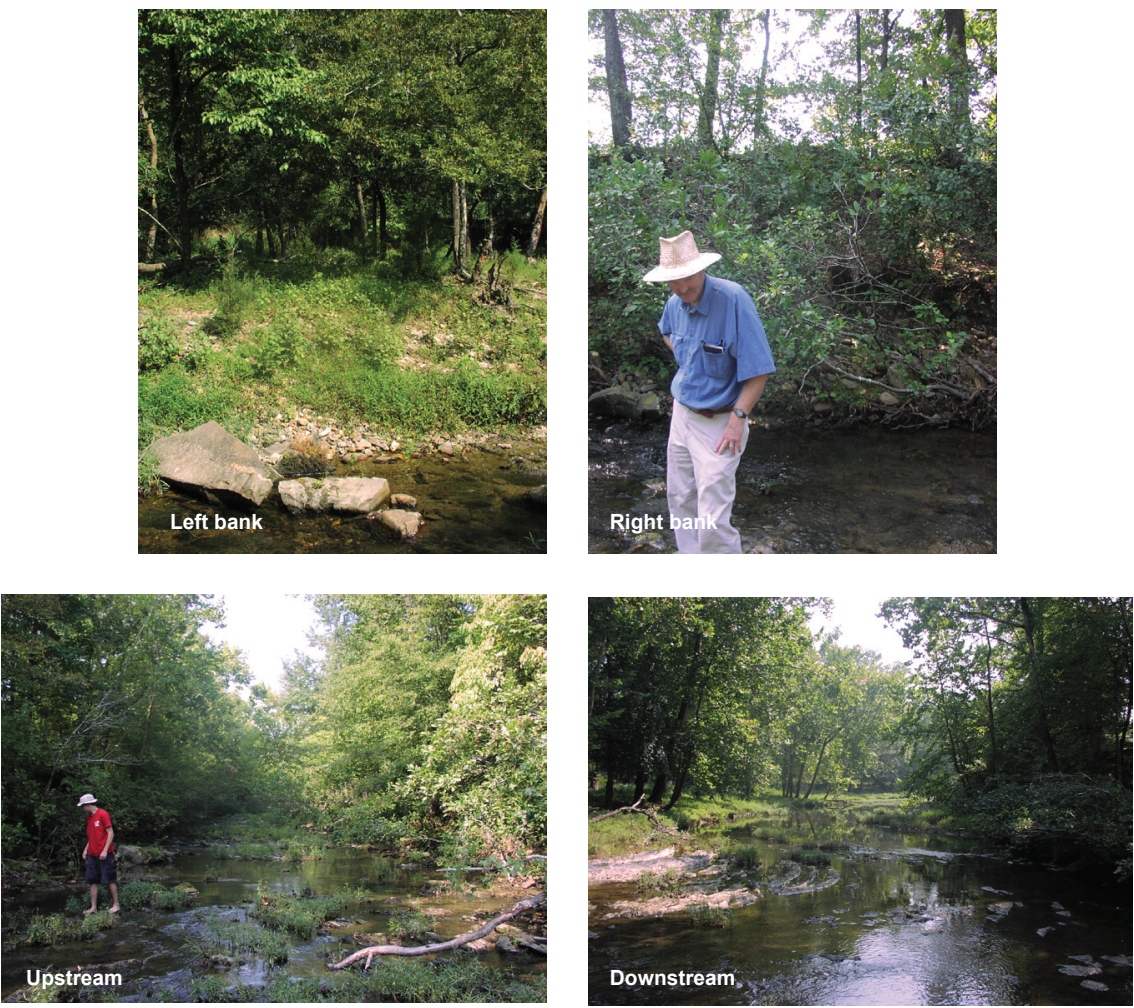


\section{APPENDIX 3: Above Coleman Creek}

\section{Drainage Area: $16.5 \mathrm{mi}^{2}$}

\section{LOCATION}

Reach: Above confluence with Coleman Creek County: Garland

Quadrangle map: Jessieville

Section: NW1/4 NW1/4 Sect.34

Township: 1 North

Range: 19 West

\section{BANKFULL CHARACTERISTICS}

Stage: $6.2 \mathrm{ft}$ above thalweg

Cross-sectional area: $271.3 \mathrm{ft}^{2}$

Top width: $150.5 \mathrm{ft}$

Mean depth: $1.8 \mathrm{ft}$

Hydraulic radius: $1.8 \mathrm{ft}$
Slope: $0.0029 \mathrm{ft} / \mathrm{ft}$

Tractive force: $0.32 \mathrm{lbf} / \mathrm{ft}^{2}$

Particle size transported: $32 \mathrm{~mm}$

Portion of bed material transported: 51.0 percent

\section{STREAM CLASSIFICATION}

Flood prone width: $710 \mathrm{ft}$

Entrenchment ratio: 4.7

Stream type: $\mathrm{C}_{/ 1}$
Width to depth ratio: 83.6

Sinuosity: 1.38

\section{LOCATION AERIAL PHOTOGRAPH - MAP}

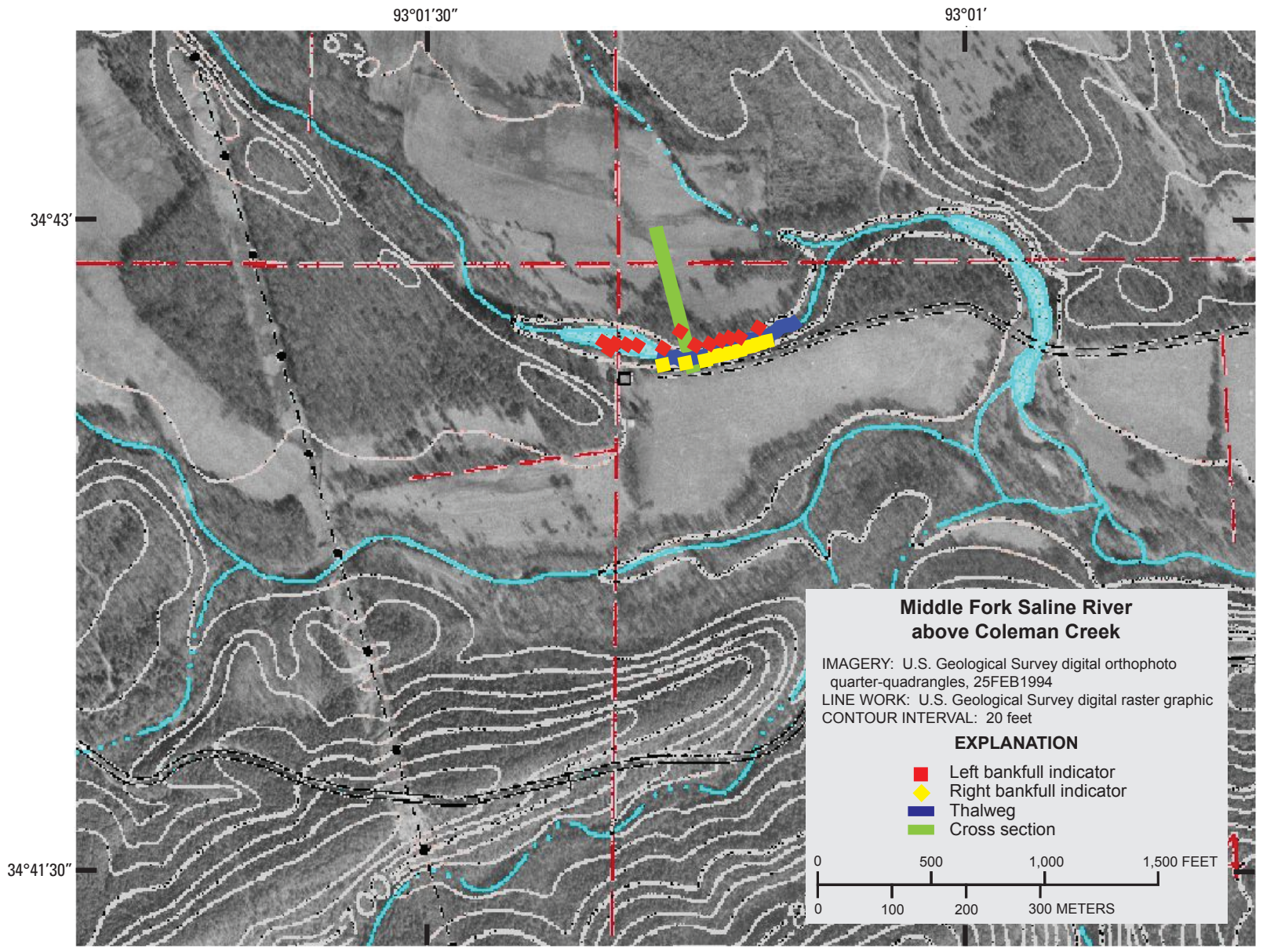




\section{SITE SURVEY DATA PLOTS}
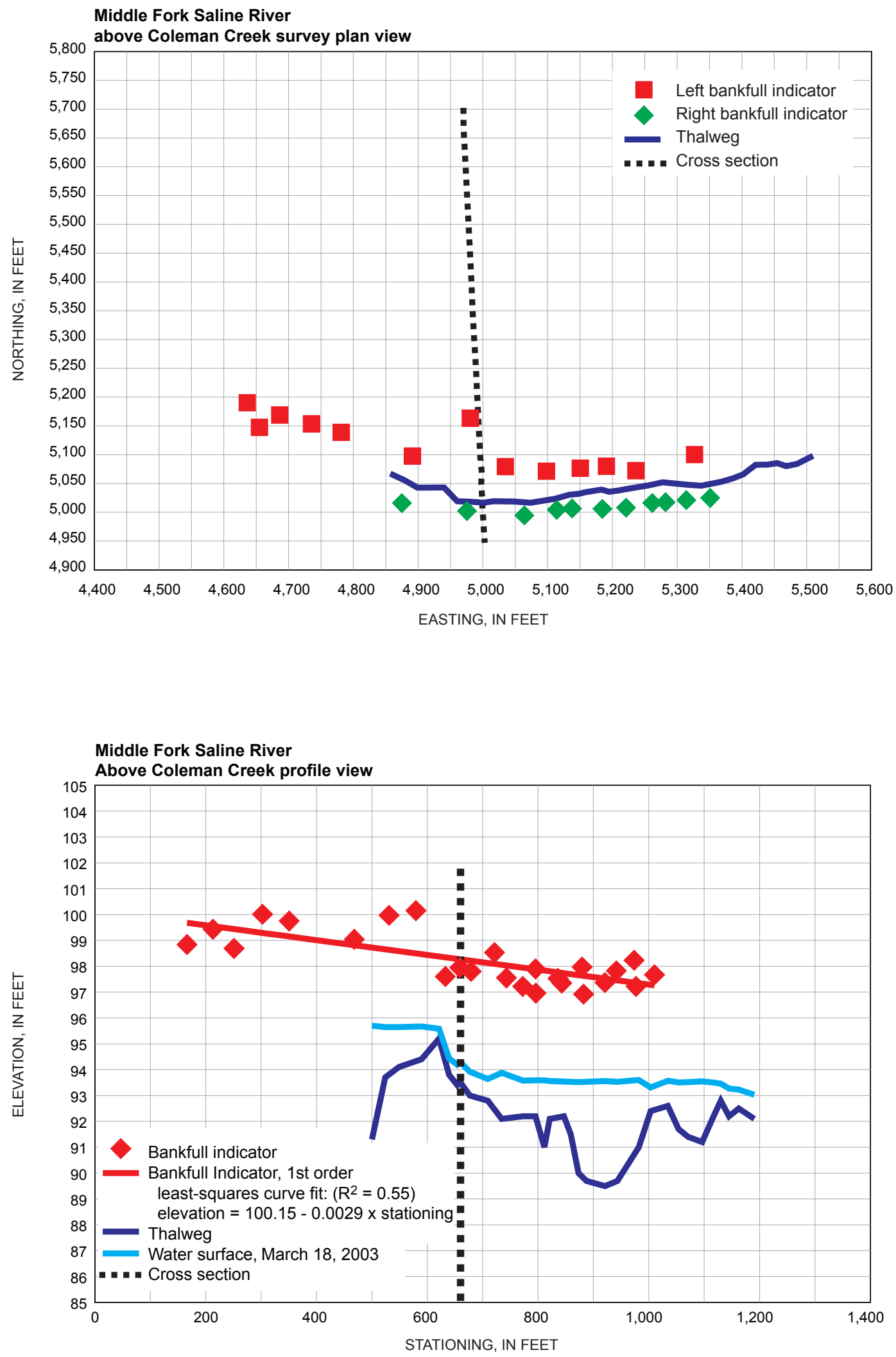


\section{APPENDIX 3: Above Coleman Creek}

Drainage Area: $16.5 \mathrm{mi}^{2}$

\section{SITE SURVEY DATA PLOTS}
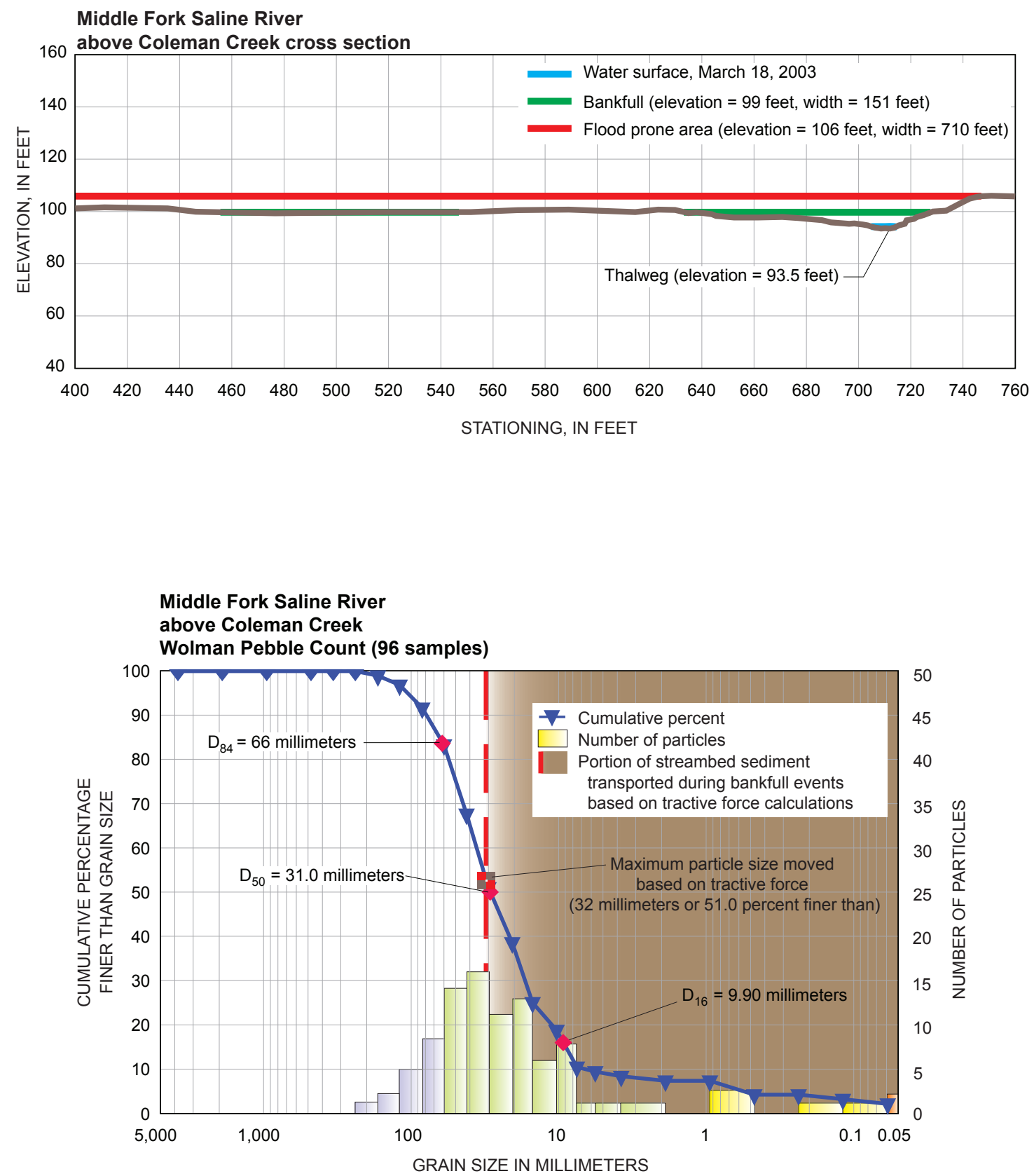

Percent (\%) by particle type based on total count (99):

\begin{tabular}{c|c|c|c|c|c}
\hline Bedrock & Boulder & Cobble & Gravel & Sand & Silt or Clay \\
$3 \%$ & $16 \%$ & $74 \%$ & $5 \%$ & $2 \%$ \\
\hline
\end{tabular}




\section{PHOTOGRAPHS OF CROSS SECTION}

Middle Fork Saline River above Coleman Creek, March 18, 2003
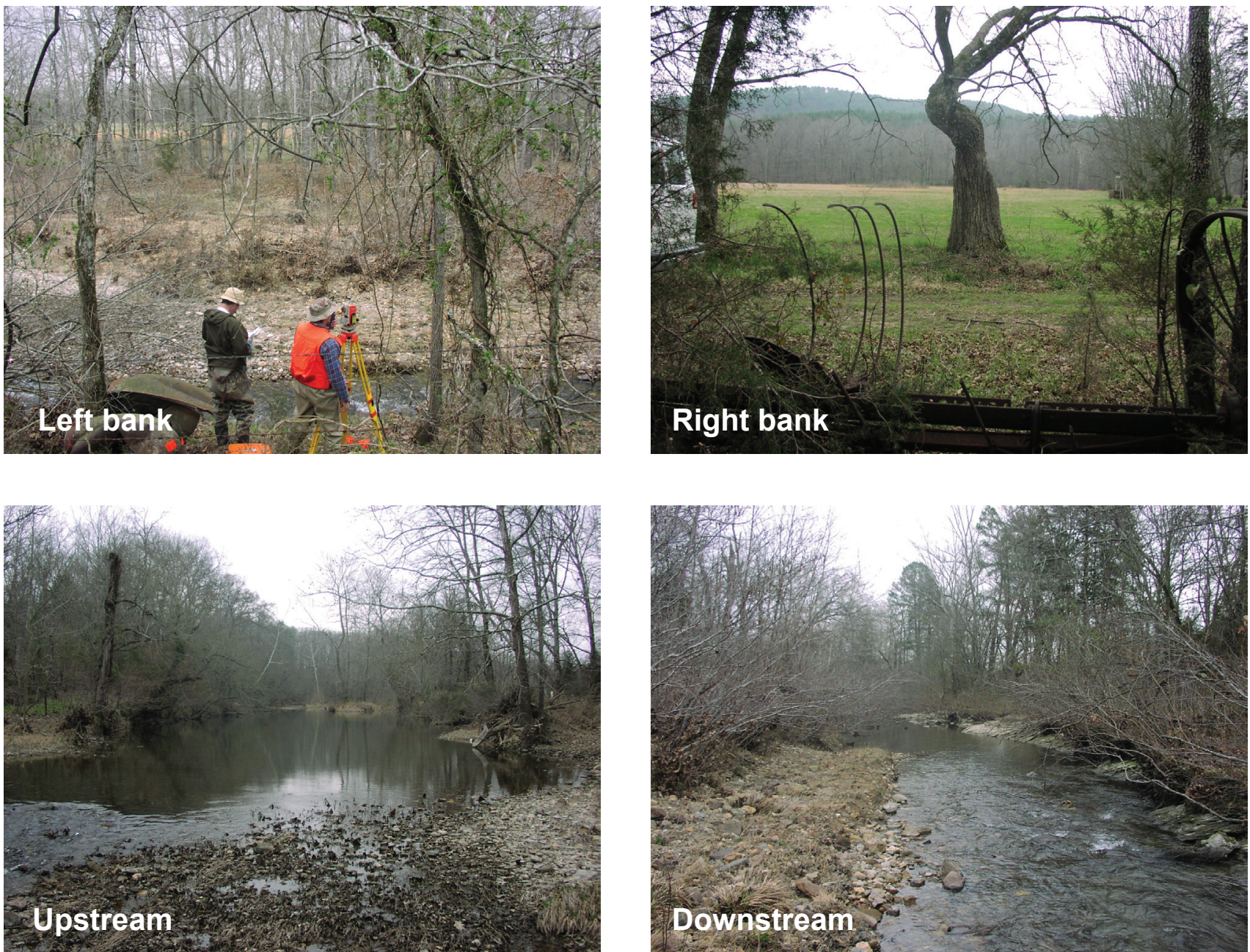


\section{APPENDIX 4: Coleman Creek}

\section{LOCATION}

Reach: Above confluence with Middle Fork County: Garland

Quadrangle map: Jessieville

\section{BANKFULL CHARACTERISTICS}

Stage: $4.9 \mathrm{ft}$ above thalweg

Cross-sectional area: $196.4 \mathrm{ft}^{2}$

Top width: $99.3 \mathrm{ft}$

Mean depth: $2.0 \mathrm{ft}$

Hydraulic radius: $1.9 \mathrm{ft}$

\section{STREAM CLASSIFICATION}

Flood prone width: $458 \mathrm{ft}$

Entrenchment ratio: 4.6

Stream type: $\mathrm{C}_{/ 1}$

\section{Drainage Area: $10.9 \mathrm{mi}^{2}$}

Section: NW1/4 NW1/4 Sect. 34

Township: 1 North

Range: 19 West

Slope: $0.0026 \mathrm{ft} / \mathrm{ft}$

Tractive force: $0.32 \mathrm{lbf} / \mathrm{ft}^{2}$

Particle size transported: $16 \mathrm{~mm}$

Portion of bed material transported: 40.0 percent

Width to depth ratio: 50

Sinuosity: 1.09

\section{LOCATION AERIAL PHOTOGRAPH - MAP}

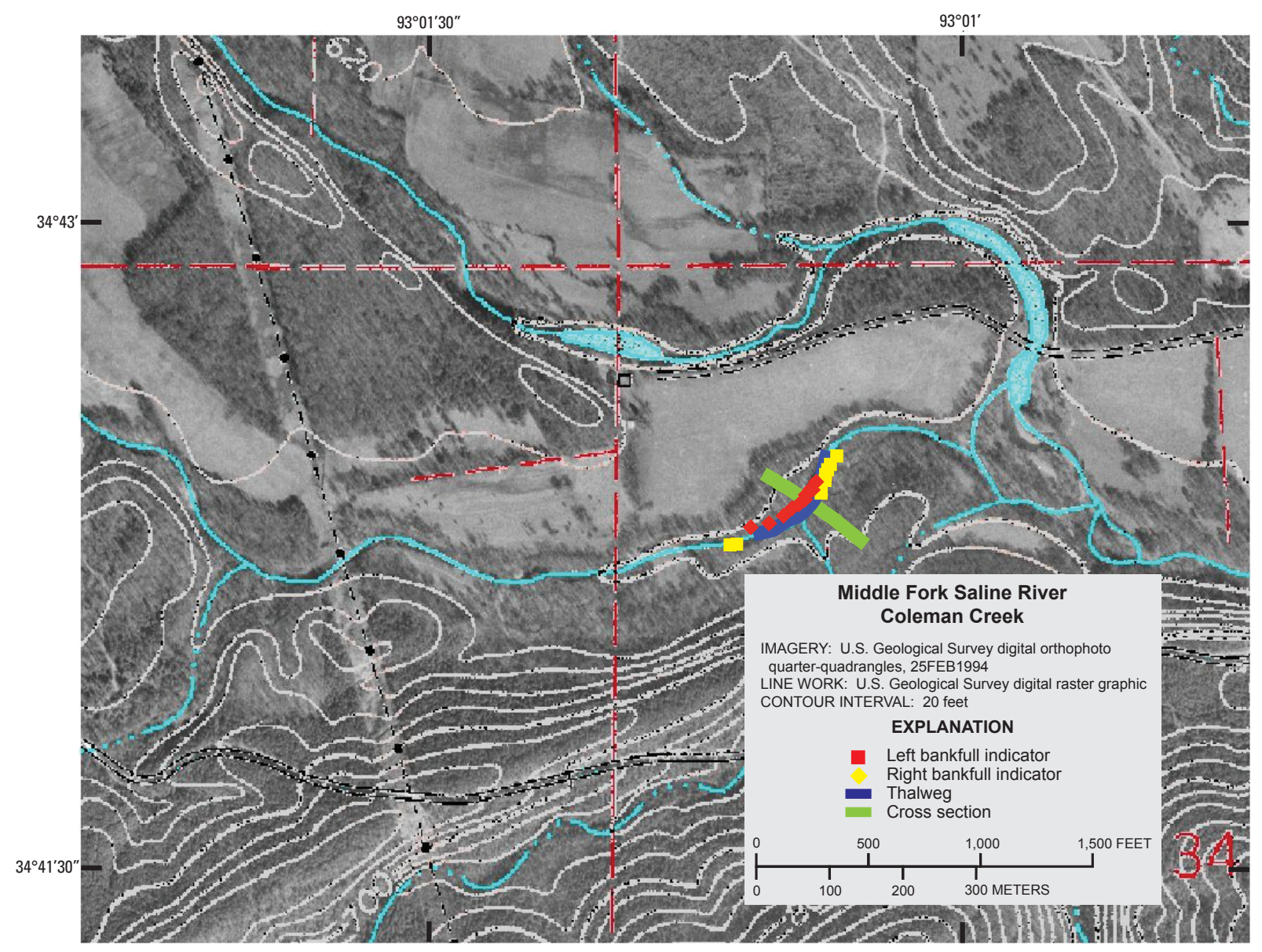




\section{SITE SURVEY DATA PLOTS}
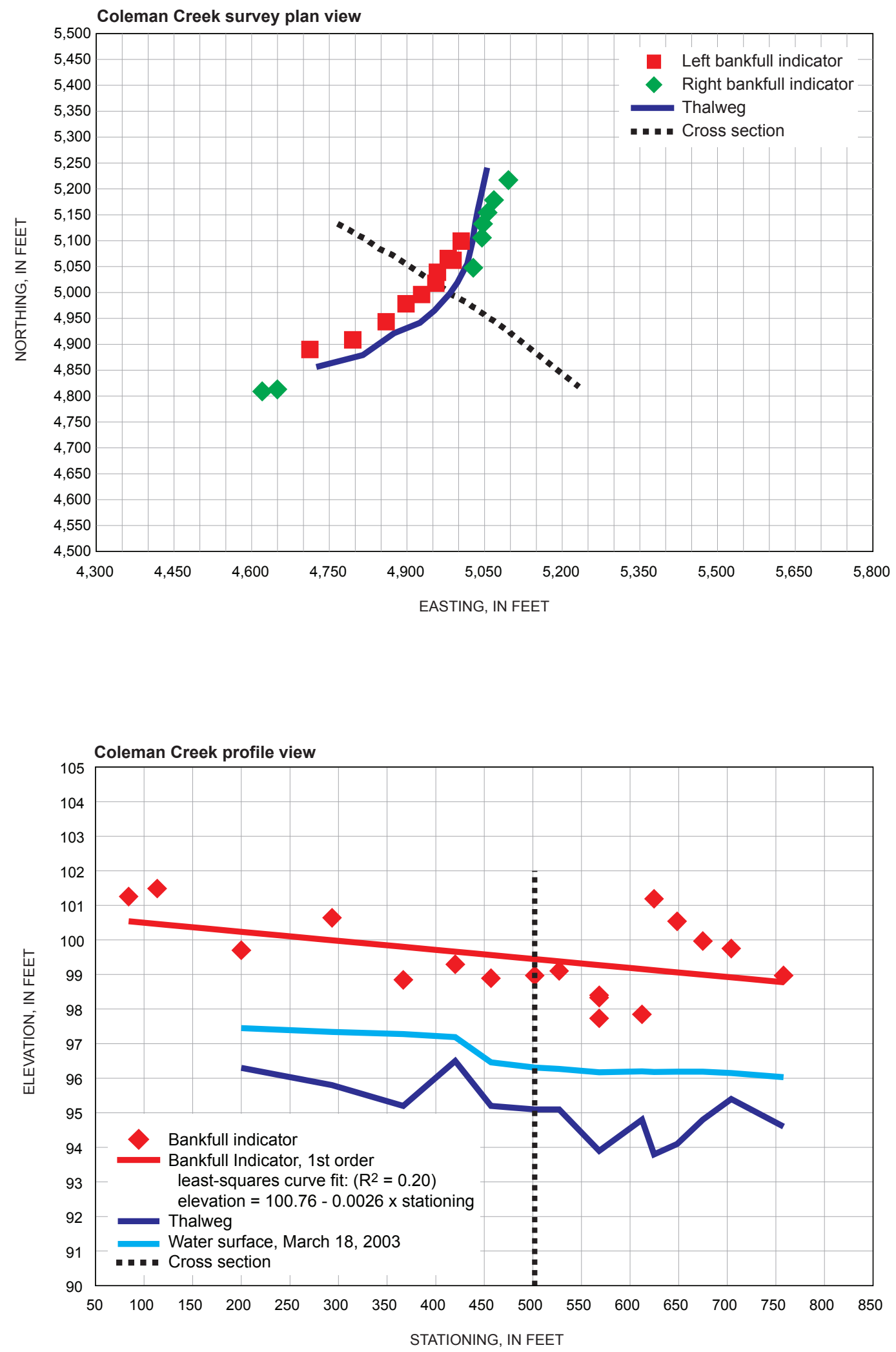


\section{APPENDIX 4: Coleman Creek}

\section{Drainage Area: $10.9 \mathrm{mi}^{2}$}

\section{SITE SURVEY DATA PLOTS}
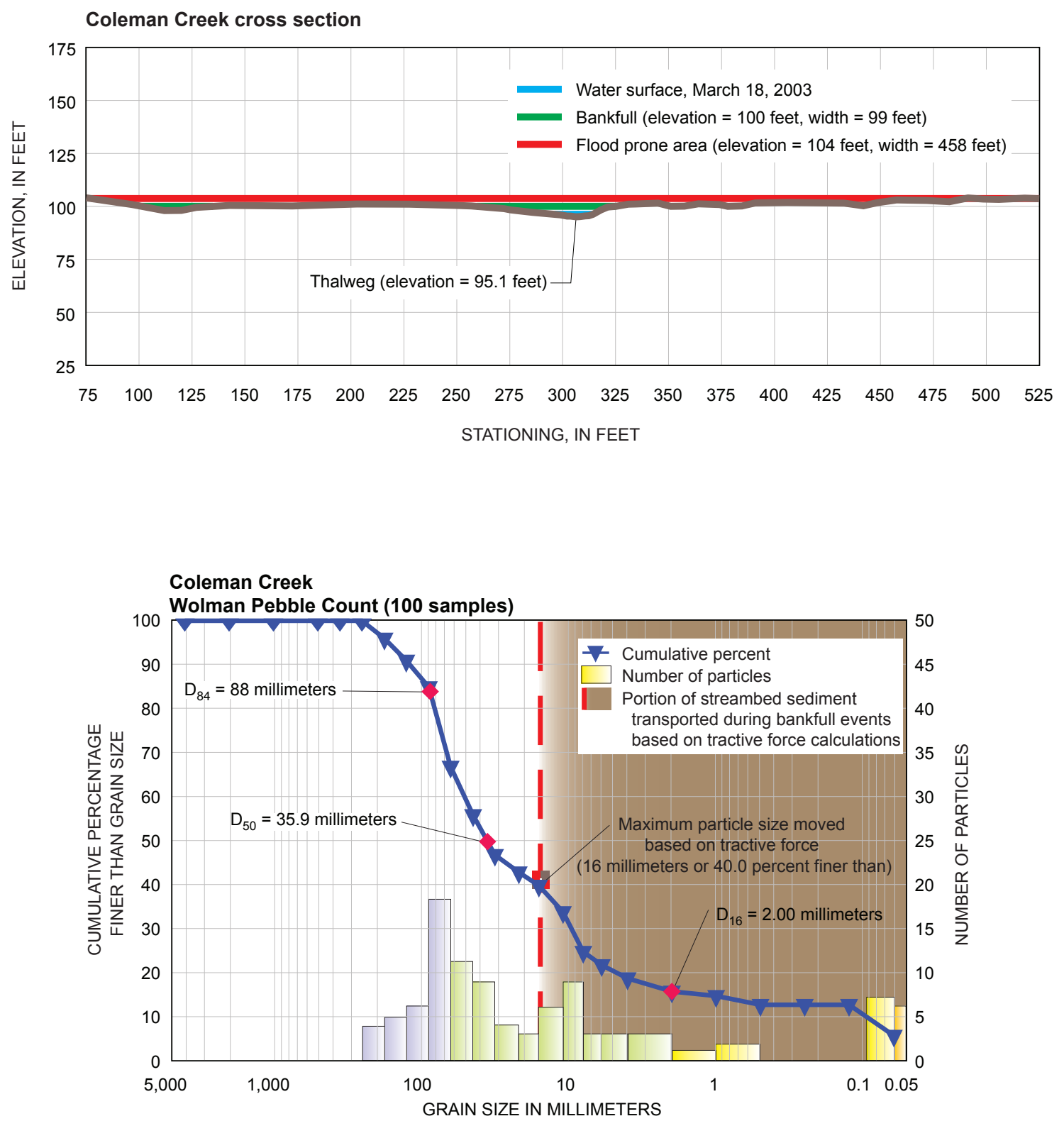

Percent (\%) by particle type based on total count (100):

\begin{tabular}{c|c|c|c|c|c}
\hline $\begin{array}{c}\text { Bed- } \\
\text { rock }\end{array}$ & Boulder & Cobble & Gravel & Sand & Silt or Clay \\
\end{tabular}




\section{APPENDIX 4: Coleman Creek}

\section{PHOTOGRAPHS OF CROSS SECTIONS}

Coleman Creek, March 18, 2003
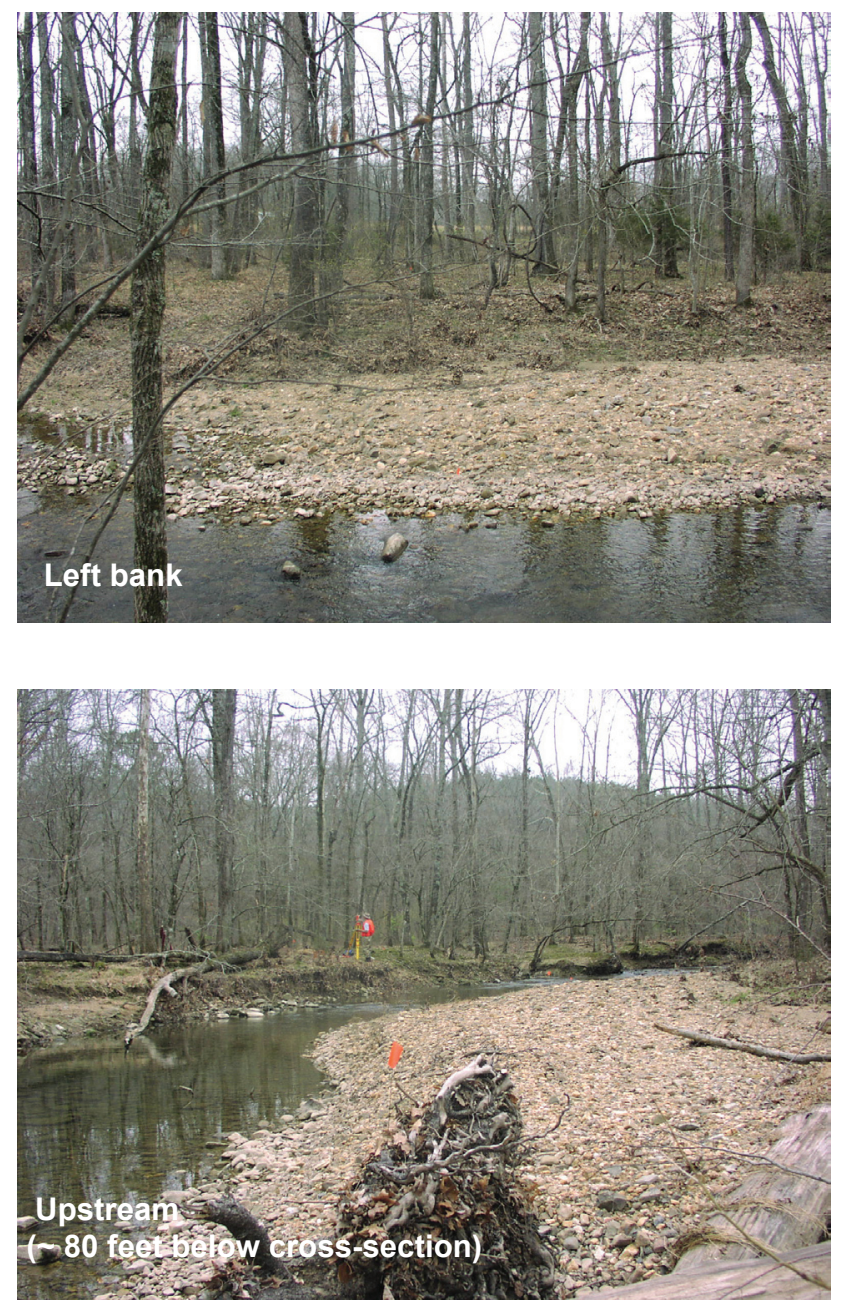

\section{Drainage Area: $10.9 \mathrm{mi}^{2}$}
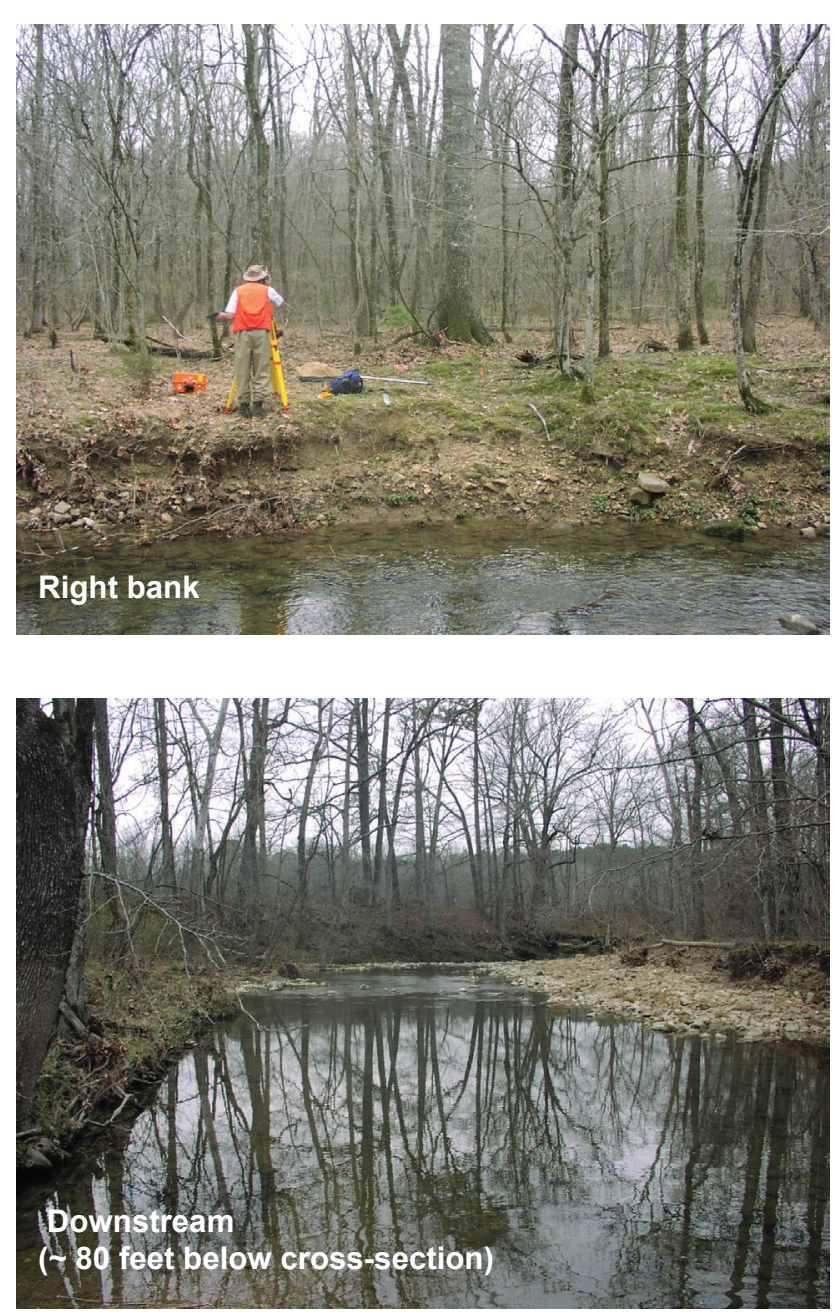


\section{APPENDIX 5: Talley Cemetery Road}

\section{Drainage Area: $29.9 \mathrm{mi}^{2}$}

\section{LOCATION}

Reach: $~ 900 \mathrm{ft}$ above Talley Cemetery Road Bridge County: Garland

Quadrangle map: Goosepond Mountain

\section{BANKFULL CHARACTERISTICS}

Stage: $7.2 \mathrm{ft}$ above thalweg

Cross-sectional area: $461.4 \mathrm{ft}^{2}$

Top width: $111.1 \mathrm{ft}$

Mean depth: $4.2 \mathrm{ft}$

Hydraulic radius: $4.0 \mathrm{ft}$

\section{STREAM CLASSIFICATION}

Flood prone width: $261 \mathrm{ft}$

Entrenchment ratio: 2.4

Stream type: $\mathrm{C}_{/ 1}$
Section: SW1/4 SW1/4 Sect. 25

Township: 1 North

Range: 19 West

Slope: $0.0024 \mathrm{ft} / \mathrm{ft}$

Tractive force: $0.60 \mathrm{lbf} / \mathrm{ft}^{2}$

Particle size transported: $31 \mathrm{~mm}$

Portion of bed material transported: 52.2 percent

\section{LOCATION AERIAL PHOTOGRAPH - MAP}

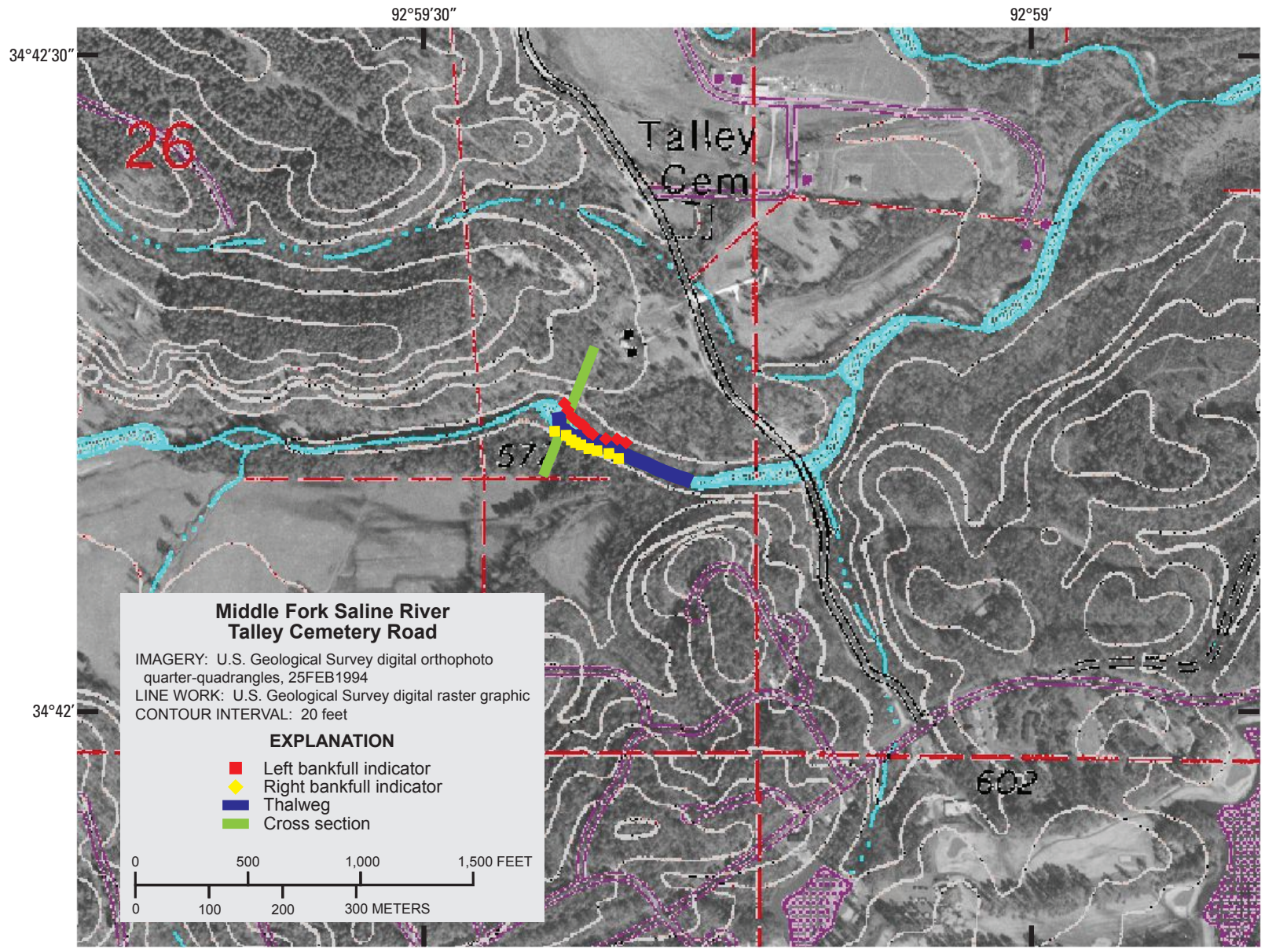




\section{APPENDIX 5: Talley Cemetery Road}

\section{Drainage Area: $29.9 \mathrm{mi}^{2}$}

\section{SITE SURVEY DATA PLOTS}
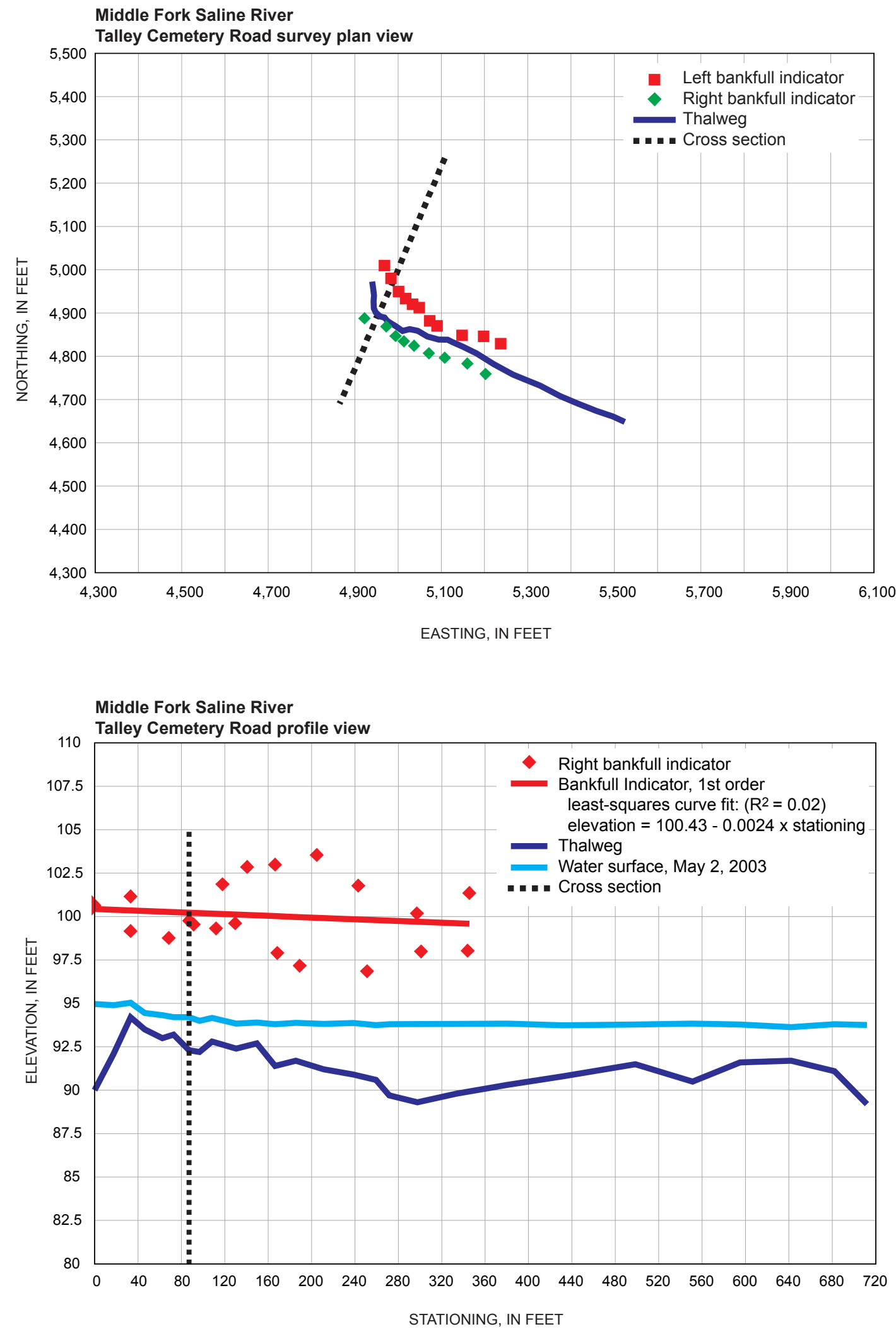


\section{APPENDIX 5: Talley Cemetery Road}

\section{Drainage Area: $29.9 \mathrm{mi}^{2}$}

\section{SITE SURVEY DATA PLOTS}
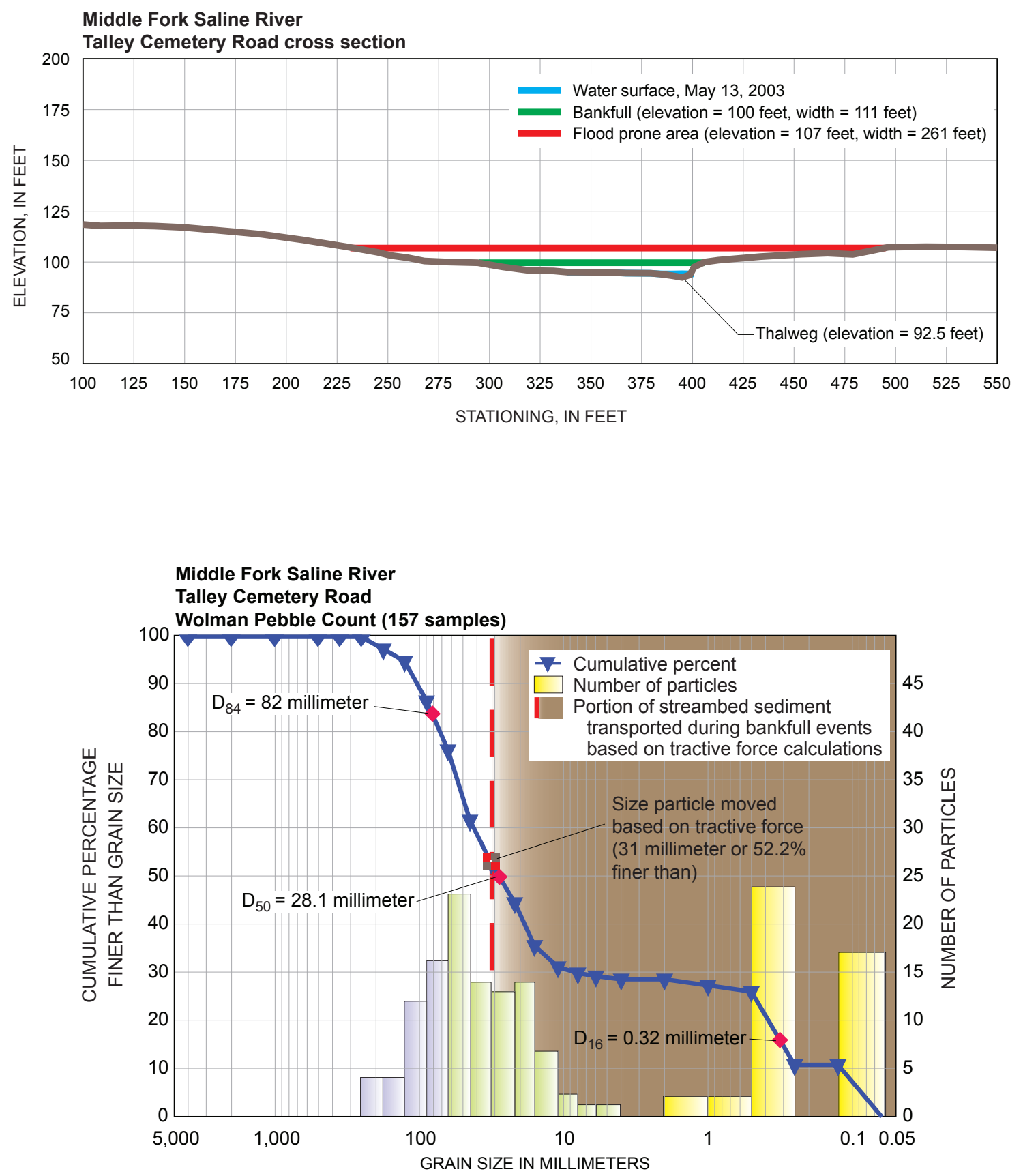

Percent (\%) by particle type based on total count (162):

\begin{tabular}{c|c|c|c|c|c}
\hline Bedrock & Boulder & Cobble & Gravel & Sand & Silt or \\
$3 \%$ & & $23 \%$ & $46 \%$ & $28 \%$ & Clay \\
\hline
\end{tabular}




\section{APPENDIX 5: Talley Cemetery Road}

\section{Drainage Area: $29.9 \mathrm{mi}^{2}$}

\section{PHOTOGRAPHS OF CROSS SECTION}

Middle Fork Saline River

Talley Cemetery Road, May 13, 2003
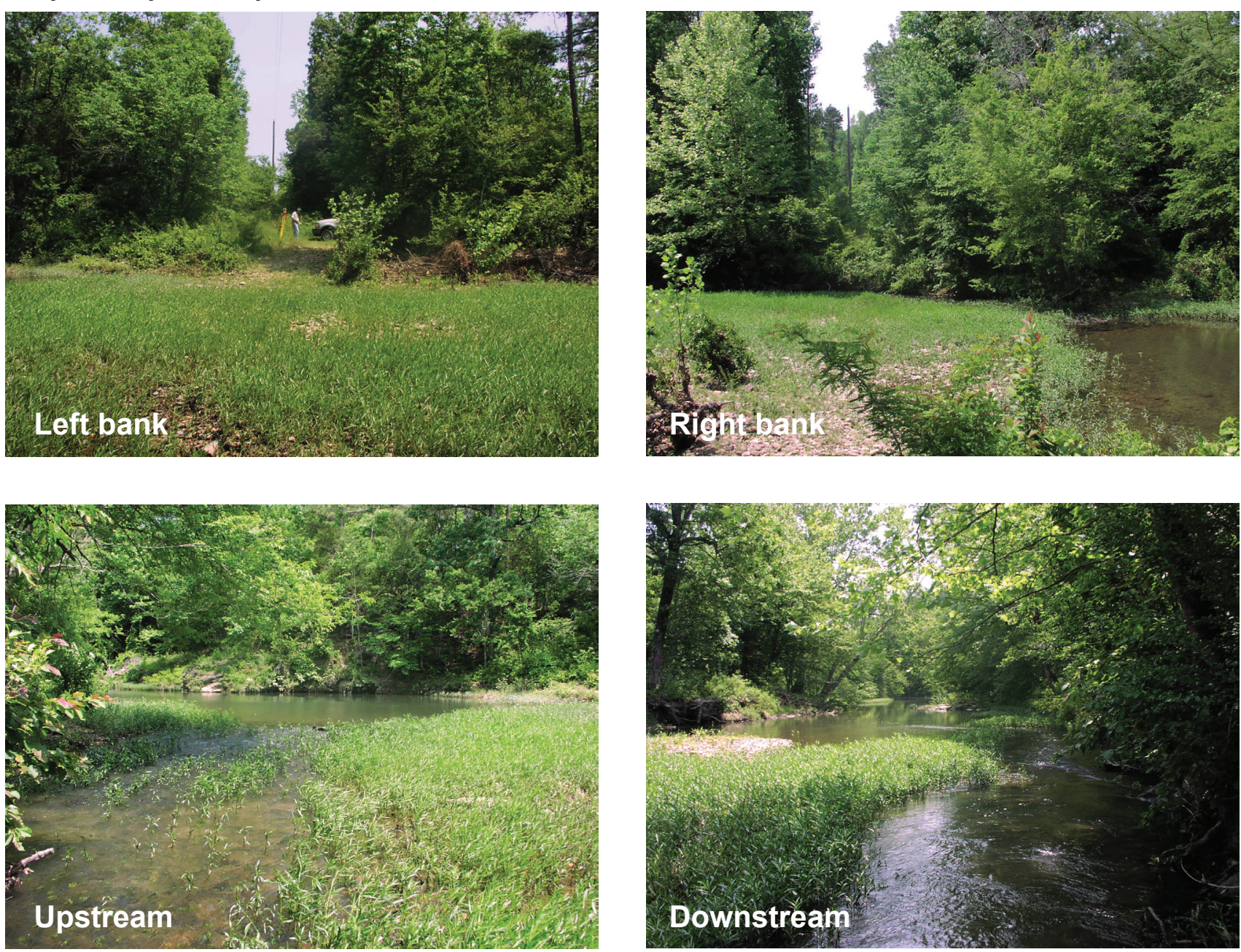


\section{APPENDIX 6: Above Mill Creek}

\section{LOCATION}

Reach: 900 ft above Talley Cemetery Road Bridge County: Saline

Quadrangle map: Goosepond Mountain

\section{BANKFULL CHARACTERISTICS}

Stage: $5.9 \mathrm{ft}$ above thalweg

Cross-sectional area: $498.6 \mathrm{ft}^{2}$

Top width: $142.0 \mathrm{ft}$

Mean depth: $3.5 \mathrm{ft}$

Hydraulic radius: $3.4 \mathrm{ft}$

\section{STREAM CLASSIFICATION}

Flood prone width: $1,130 \mathrm{ft}$

Entrenchment ratio: 8.0

Stream type: $\mathrm{C}_{/ 1}$

\section{Drainage Area: $54.3 \mathrm{mi}^{2}$}

Section: NE $1 / 4 N^{1} 1 / 4$ Sect. 31

Township: 1 North

Range: 18 West

Slope: $0.0055 \mathrm{ft} / \mathrm{ft}$

Tractive force: $1.17 \mathrm{lbf} / \mathrm{ft}^{2}$

Particle size transported: $59 \mathrm{~mm}$

Portion of bed material transported: 91.6 percent

\section{LOCATION AERIAL PHOTOGRAPH - MAP}

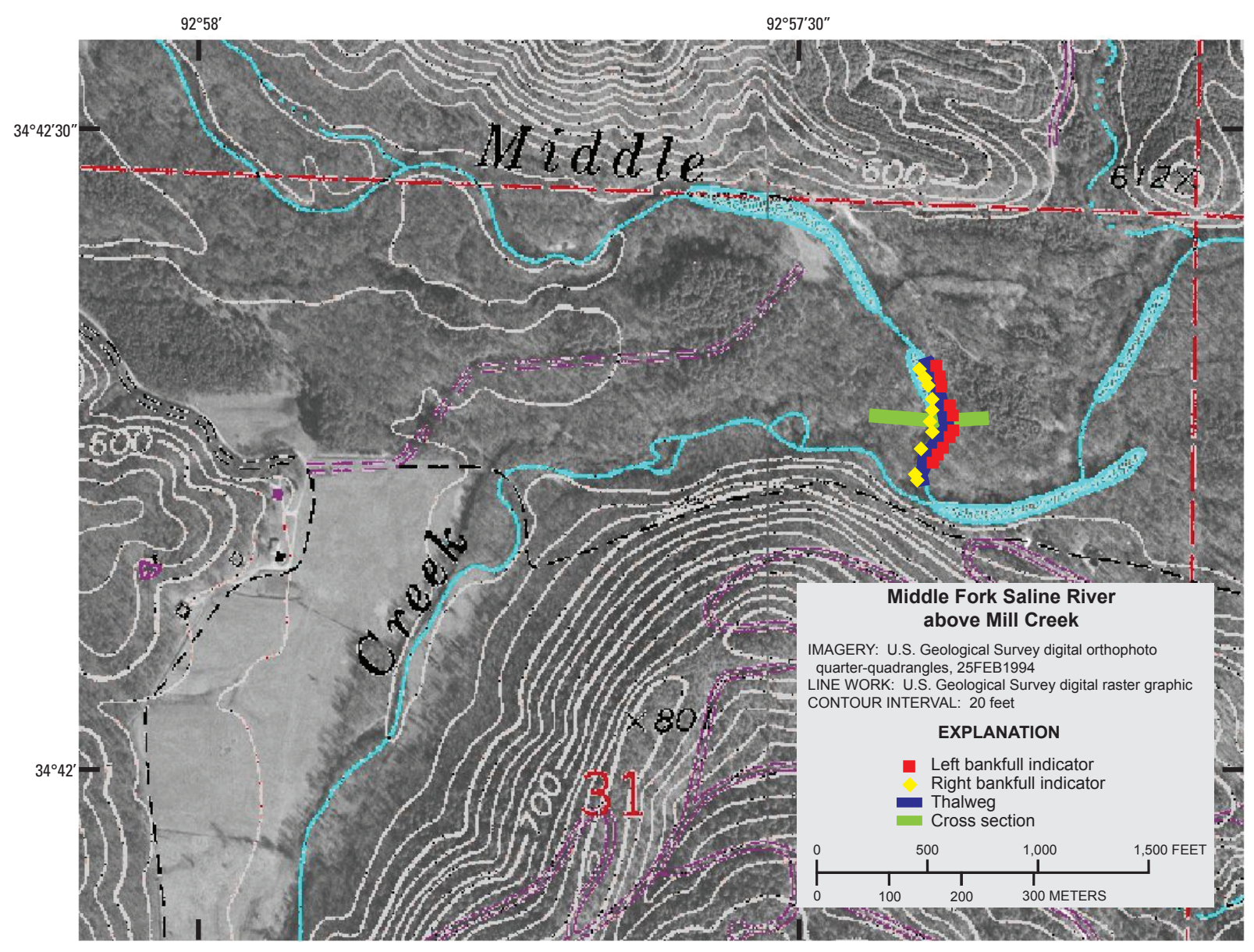




\section{APPENDIX 6: Above Mill Creek}

\section{Drainage Area: $54.3 \mathrm{mi}^{2}$}

\section{SITE SURVEY DATA PLOTS}
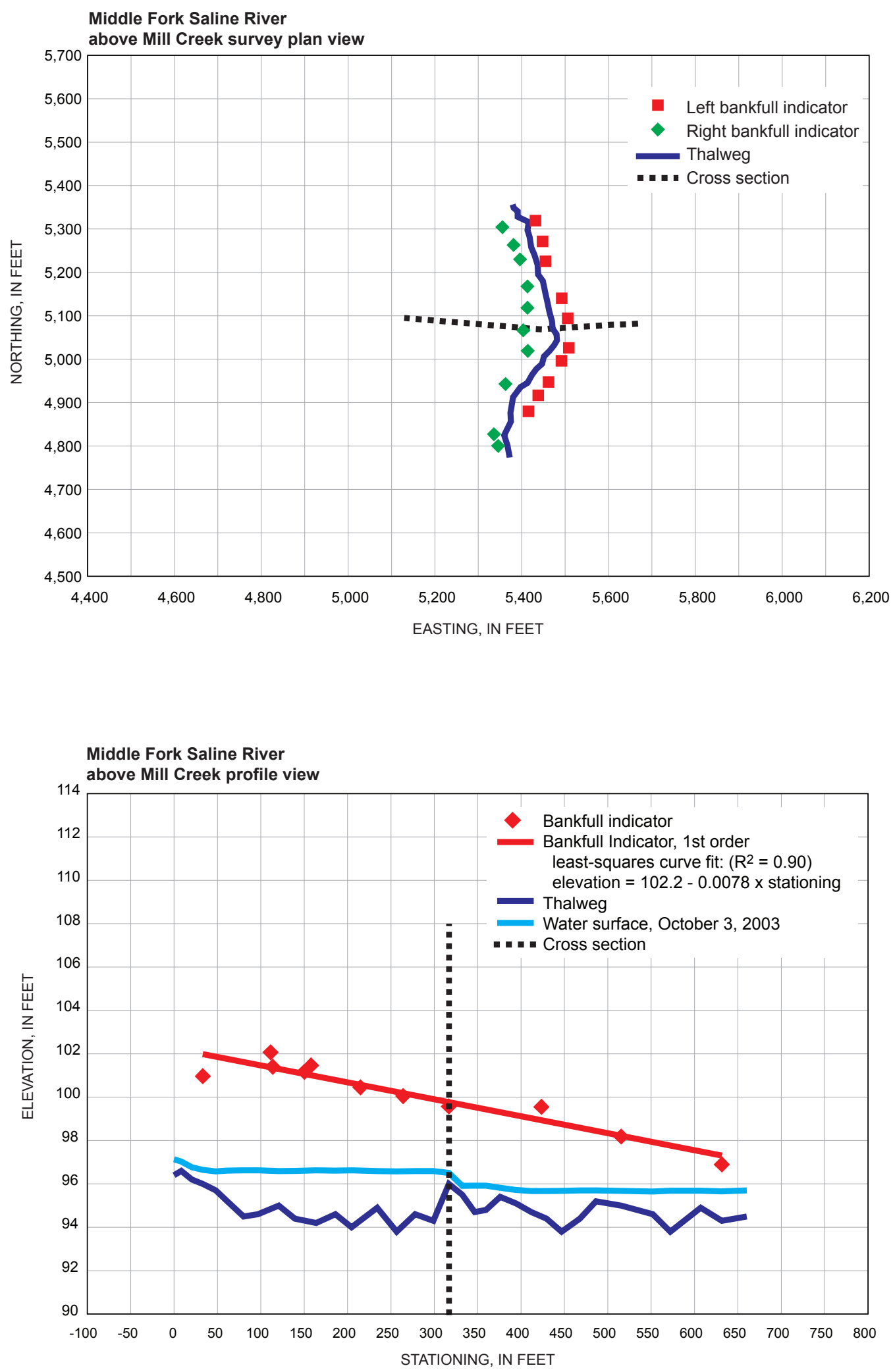


\section{APPENDIX 6: Above Mill Creek}

\section{Drainage Area: $54.3 \mathrm{mi}^{2}$}

\section{SITE SURVEY DATA PLOTS}
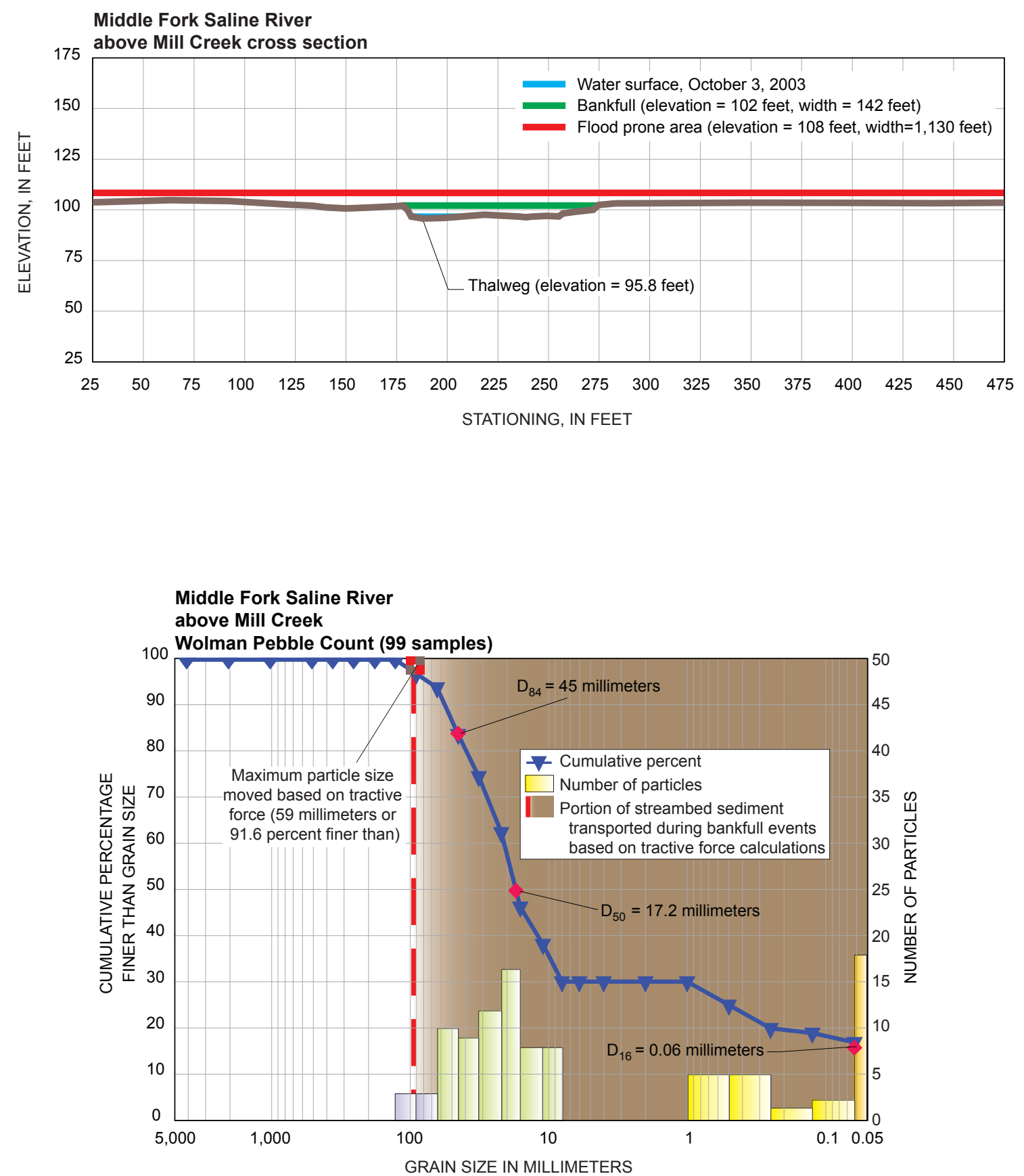

Percent (\%) by particle type based on total count (99):

\begin{tabular}{c|c|c|c|c|c}
\hline $\begin{array}{c}\text { Bed- } \\
\text { rock }\end{array}$ & Boulder & Cobble & Gravel & Sand & Silt or Clay \\
& $6 \%$ & $64 \%$ & $13 \%$ & $17 \%$ \\
\hline
\end{tabular}




\section{APPENDIX 6: Above Mill Creek}

\section{PHOTOGRAPHS OF CROSS SECTION}

Middle Fork Saline River above Mill Creek, October 3, 2003
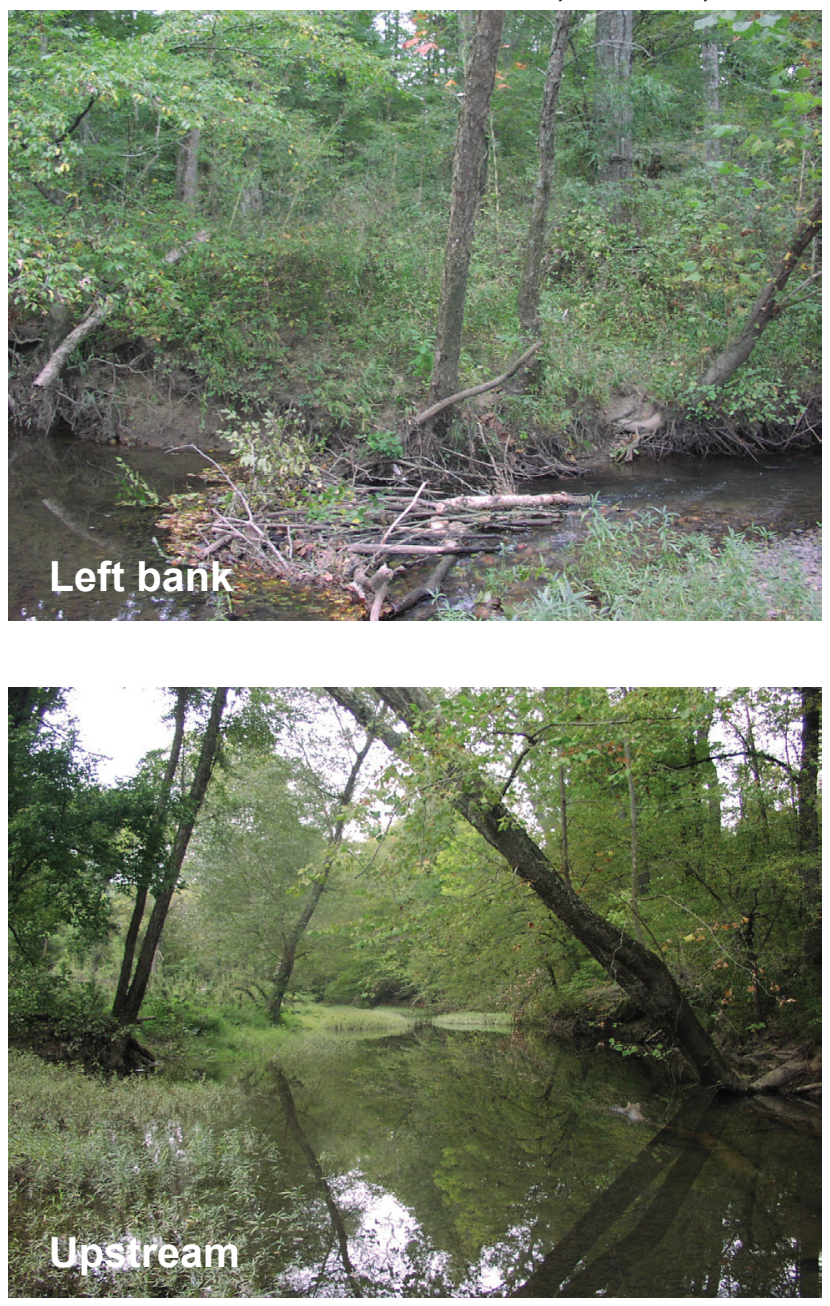

\section{Drainage Area: $54.3 \mathrm{mi}^{2}$}
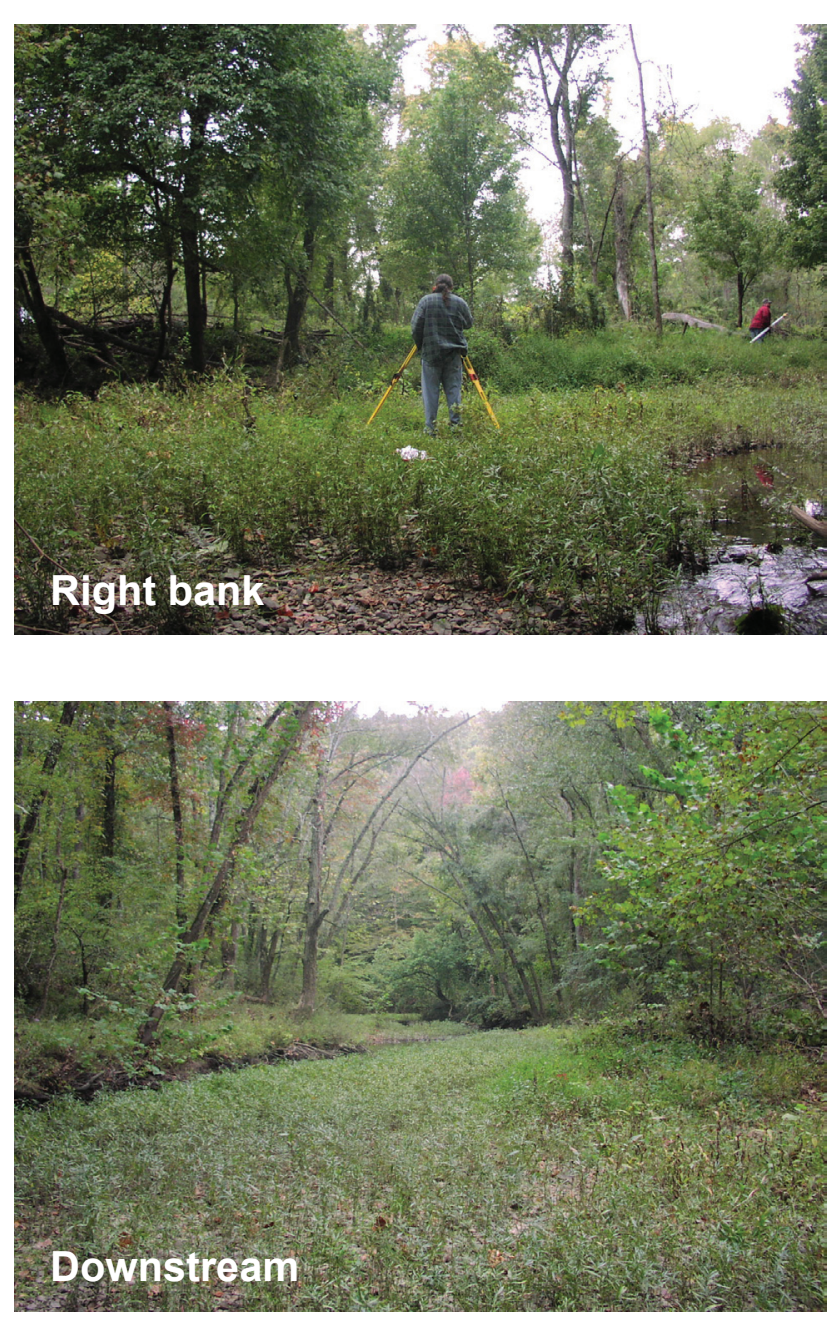


\section{APPENDIX 7: Mill Creek}

\section{Drainage Area: $10.0 \mathrm{mi}^{2}$ (uncontrolled area is $0.9 \mathrm{mi}^{2}$ )}

\section{LOCATION}

Reach: Mill Creek above confluence with Middle Fork

County: Saline

Quadrangle map: Goosepond Mountain

Section: NW1/4 NE $1 / 4$ Sect. 31

Township: 1 North

Range: 18 West

\section{BANKFULL CHARACTERISTICS}

Stage: $2.9 \mathrm{ft}$ above thalweg

Cross-sectional area: $60.6 \mathrm{ft}^{2}$

Slope: $0.0043 \mathrm{ft} / \mathrm{ft}$

Top width: $29.6 \mathrm{ft}$

Mean depth: $2.1 \mathrm{ft}$

Hydraulic radius: $1.8 \mathrm{ft}$

Tractive force: $0.49 \mathrm{lbf} / \mathrm{ft}^{2}$

Particle size transported: $42 \mathrm{~mm}$

Portion of bed material transported: 90.0 percent

\section{STREAM CLASSIFICATION}

Flood prone width: $73 \mathrm{ft}$

Entrenchment ratio: 2.5

Width to depth ratio: 14

Sinuosity: 1.21

Stream type: $\mathrm{C}_{/ 1}$

\section{LOCATION AERIAL PHOTOGRAPH - MAP}

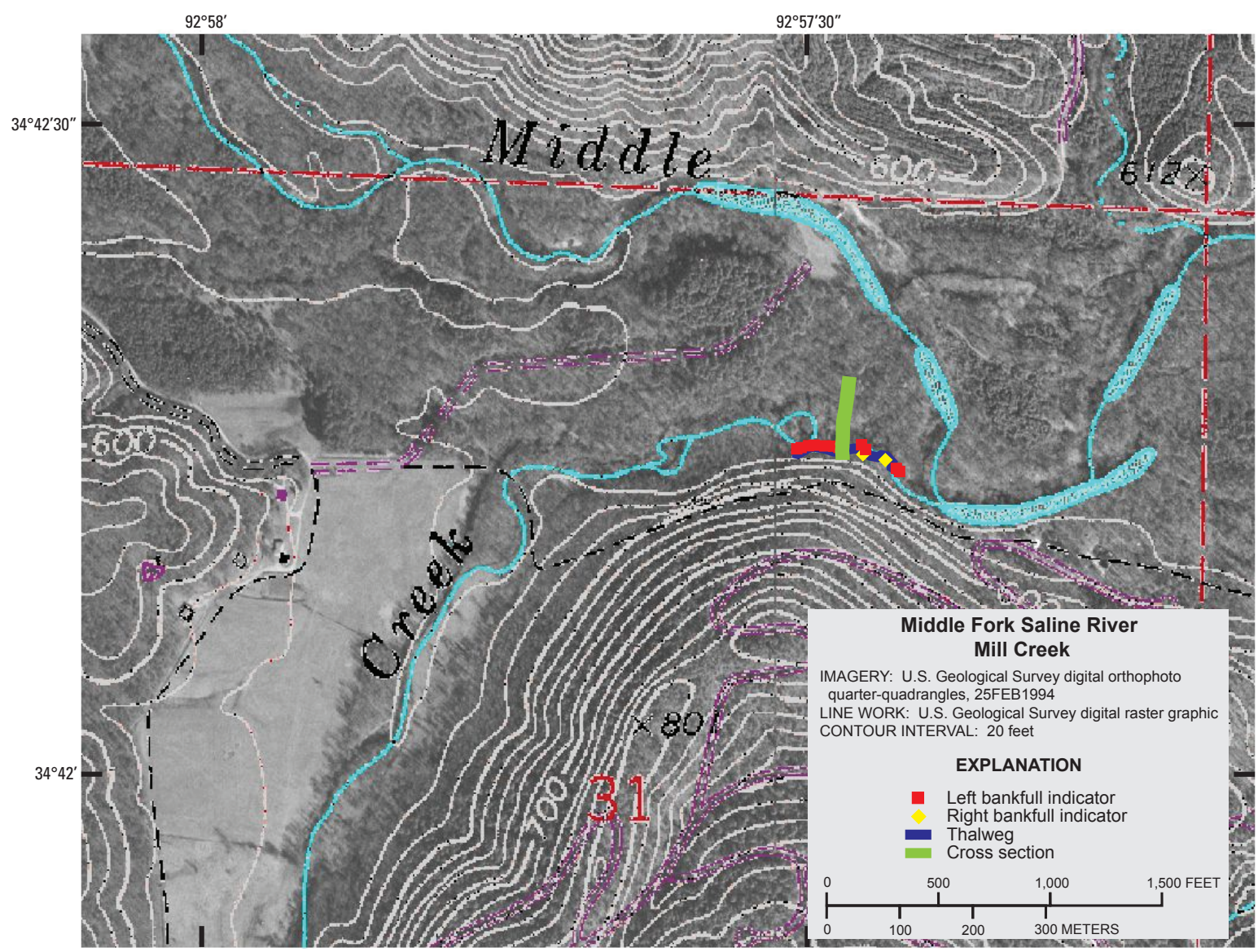


APPENDIX 7: Mill Creek

\section{Drainage Area: $10.0 \mathrm{mi}^{2}$ (uncontrolled area is $0.9 \mathrm{mi}^{2}$ )}

\section{SITE SURVEY DATA PLOTS}
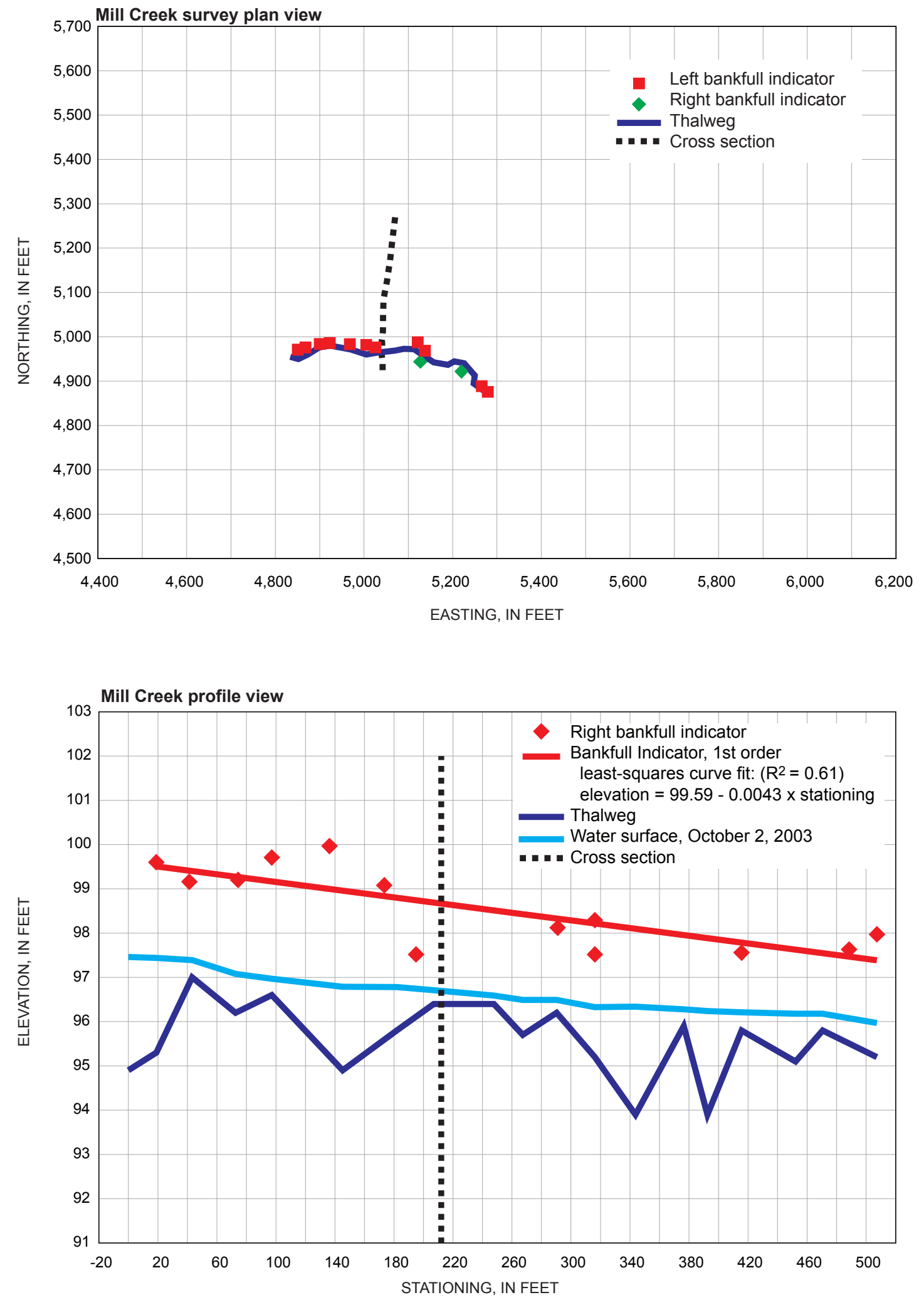


\section{APPENDIX 7: Mill Creek}

\section{Drainage Area: $10.0 \mathrm{mi}^{2}$ (uncontrolled area is $0.9 \mathrm{mi}^{2}$ )}

\section{SITE SURVEY DATA PLOTS}
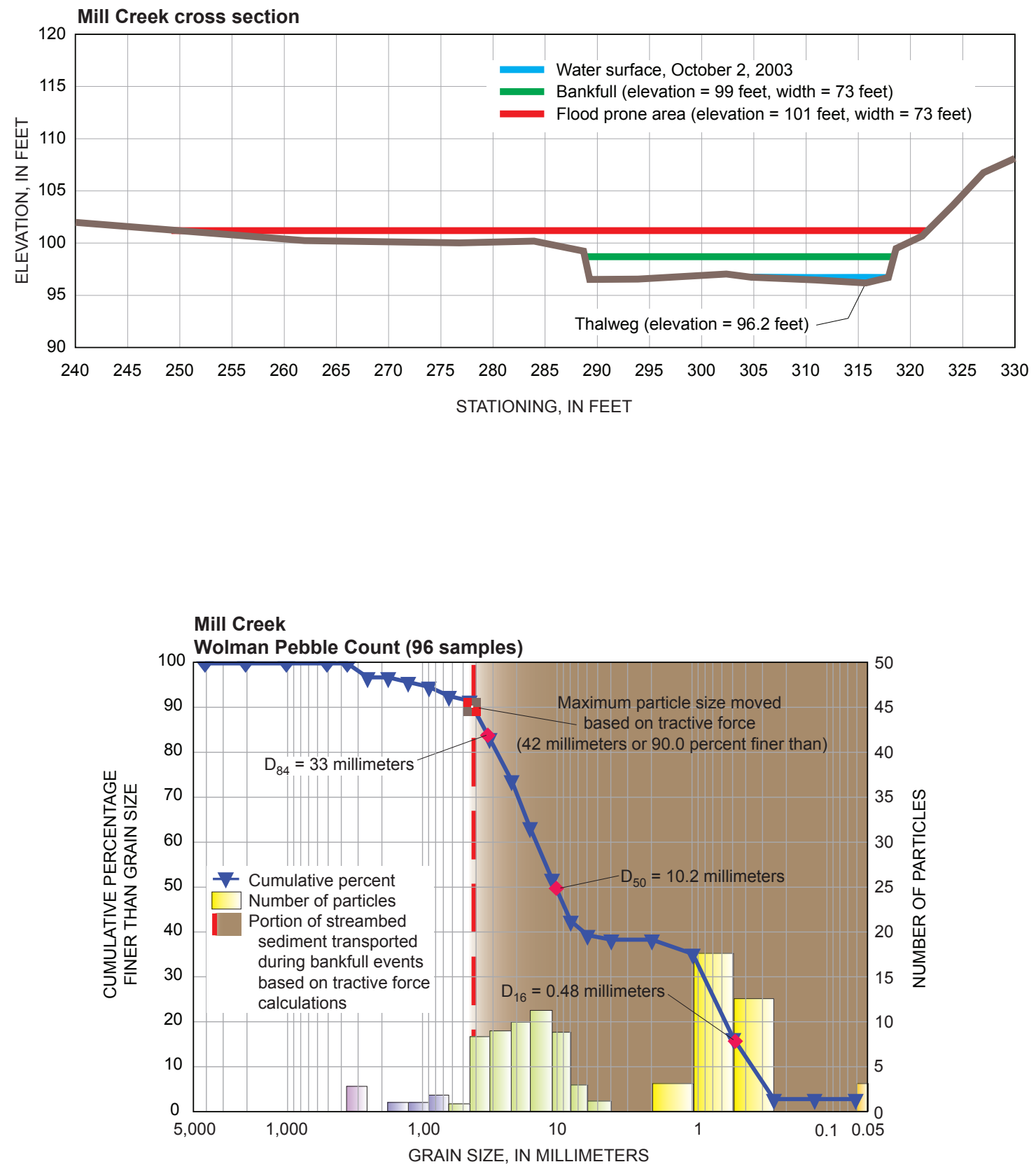

Percent (\%) by particle type based on total count (100):

\begin{tabular}{c|c|c|c|c|c}
\hline Bedrock & Boulder & Cobble & Gravel & Sand & Silt or Clay \\
$4 \%$ & $3 \%$ & $4 \%$ & $52 \%$ & $34 \%$ & $3 \%$ \\
\hline
\end{tabular}


APPENDIX 7: Mill Creek

\section{PHOTOGRAPHS OF CROSS SECTION \\ PHOTOGRAPHS OF CROSS SECTION}

Mill Creek, October 2, 2003
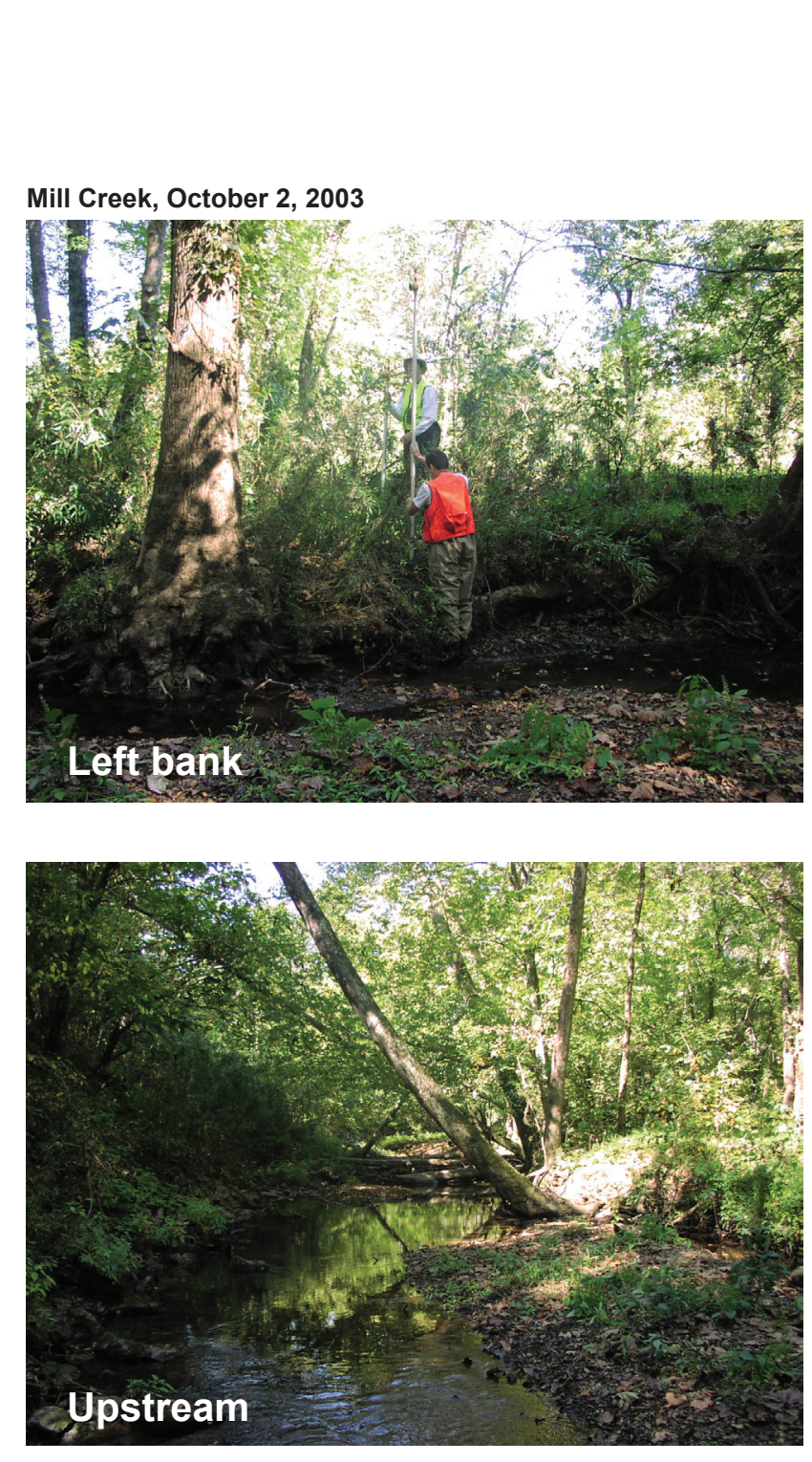

Drainage Area: $10.0 \mathrm{mi}^{2}$ (uncontrolled area is $0.9 \mathrm{mi}^{2}$ )
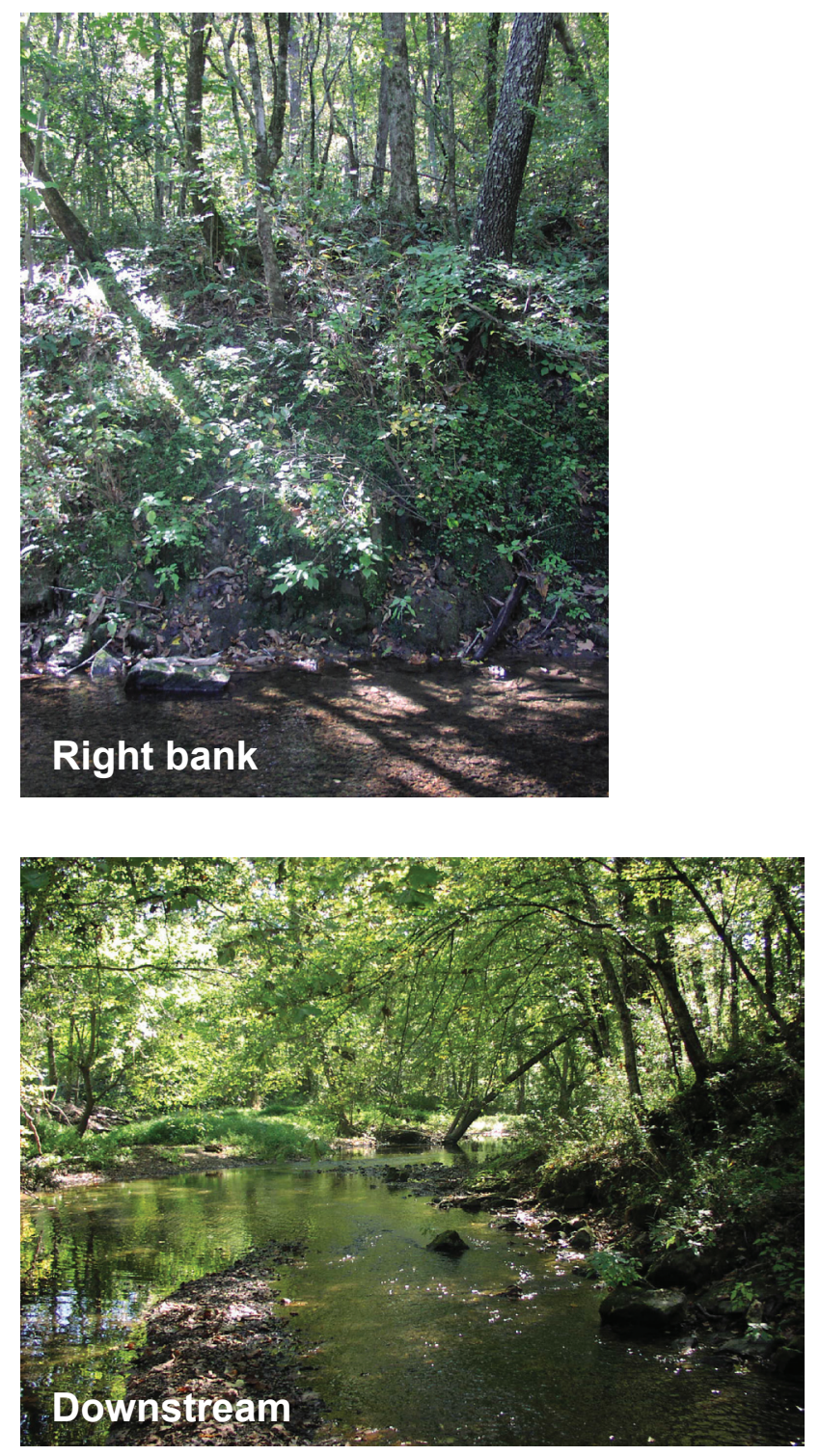


\section{APPENDIX 8: Below Danville Road}

\section{Drainage Area: $71.0 \mathrm{mi}^{2}$ (uncontrolled area is $61.9 \mathrm{mi}^{2}$ )}

\section{LOCATION}

Reach: Middle Fork below Danville Road Bridge

County: Saline

Quadrangle map: Goosepond Mountain

Section: NE 1/4 NE 1/4 Sect. 3

Township: 1 North

Range: 18 West

\section{BANKFULL CHARACTERISTICS}

Stage: $9.5 \mathrm{ft}$ above thalweg

Cross-sectional area: $691.8 \mathrm{ft}^{2}$

Top width: $250.2 \mathrm{ft}$

Mean depth: $2.8 \mathrm{ft}$

Hydraulic radius: $2.7 \mathrm{ft}$

Slope: $0.0049 \mathrm{ft} / \mathrm{ft}$

Tractive force: $0.83 \mathrm{lbf} / \mathrm{ft}^{2}$

Particle size transported: $42 \mathrm{~mm}$

Portion of bed material transported: 43.0 percent

\section{STREAM CLASSIFICATION}

Flood prone width: 2,482 ft

Width to depth ratio: 89

Entrenchment ratio: 9.9

Sinuosity: 1.19

Stream type: $\mathrm{C}_{/ 1}$

\section{LOCATION AERIAL PHOTOGRAPH - MAP}

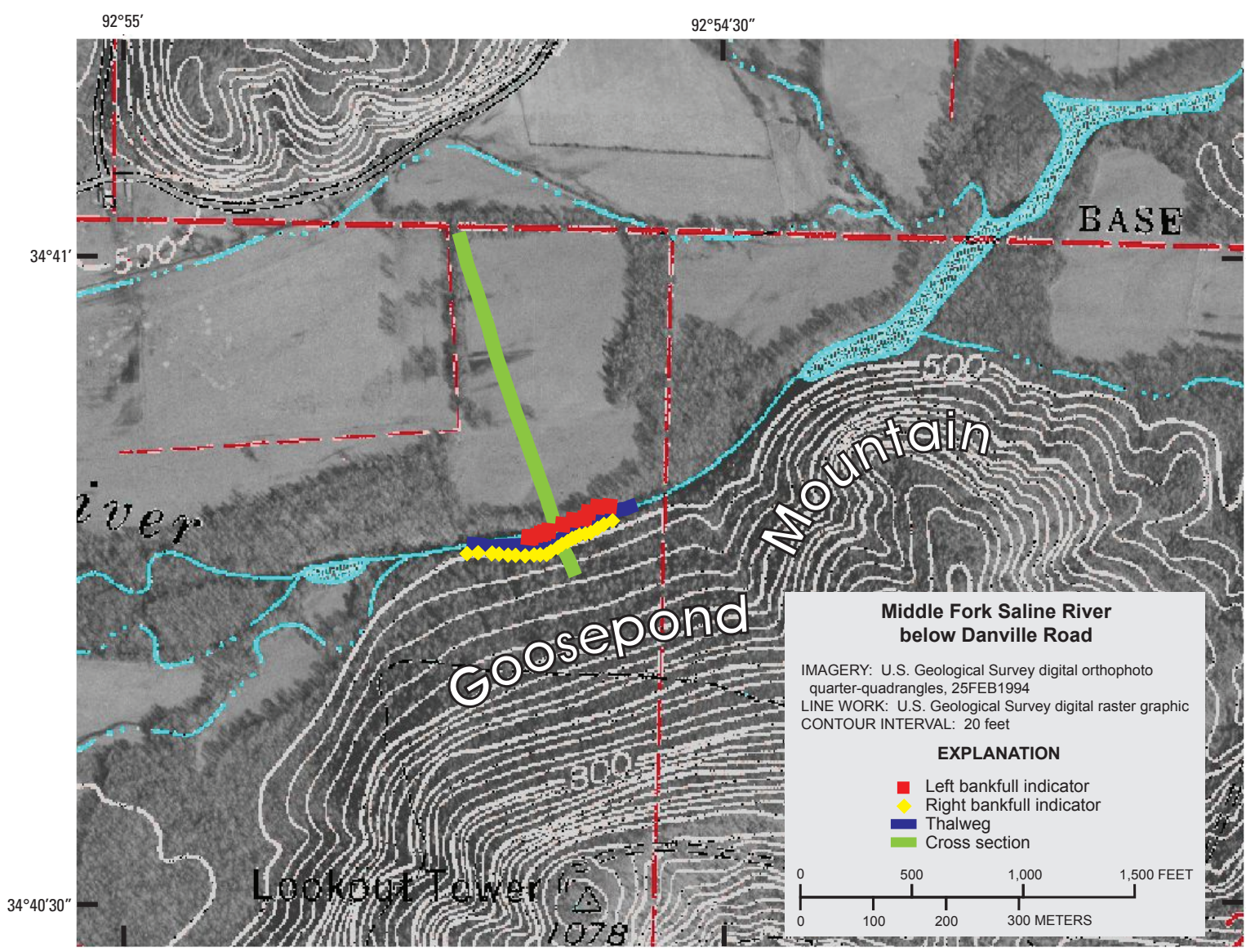




\section{APPENDIX 8: Below Danville Road \\ Drainage Area: $71.0 \mathrm{mi}^{2}$ (uncontrolled area is $61.9 \mathrm{mi}^{2}$ )}

\section{SITE SURVEY DATA PLOTS}
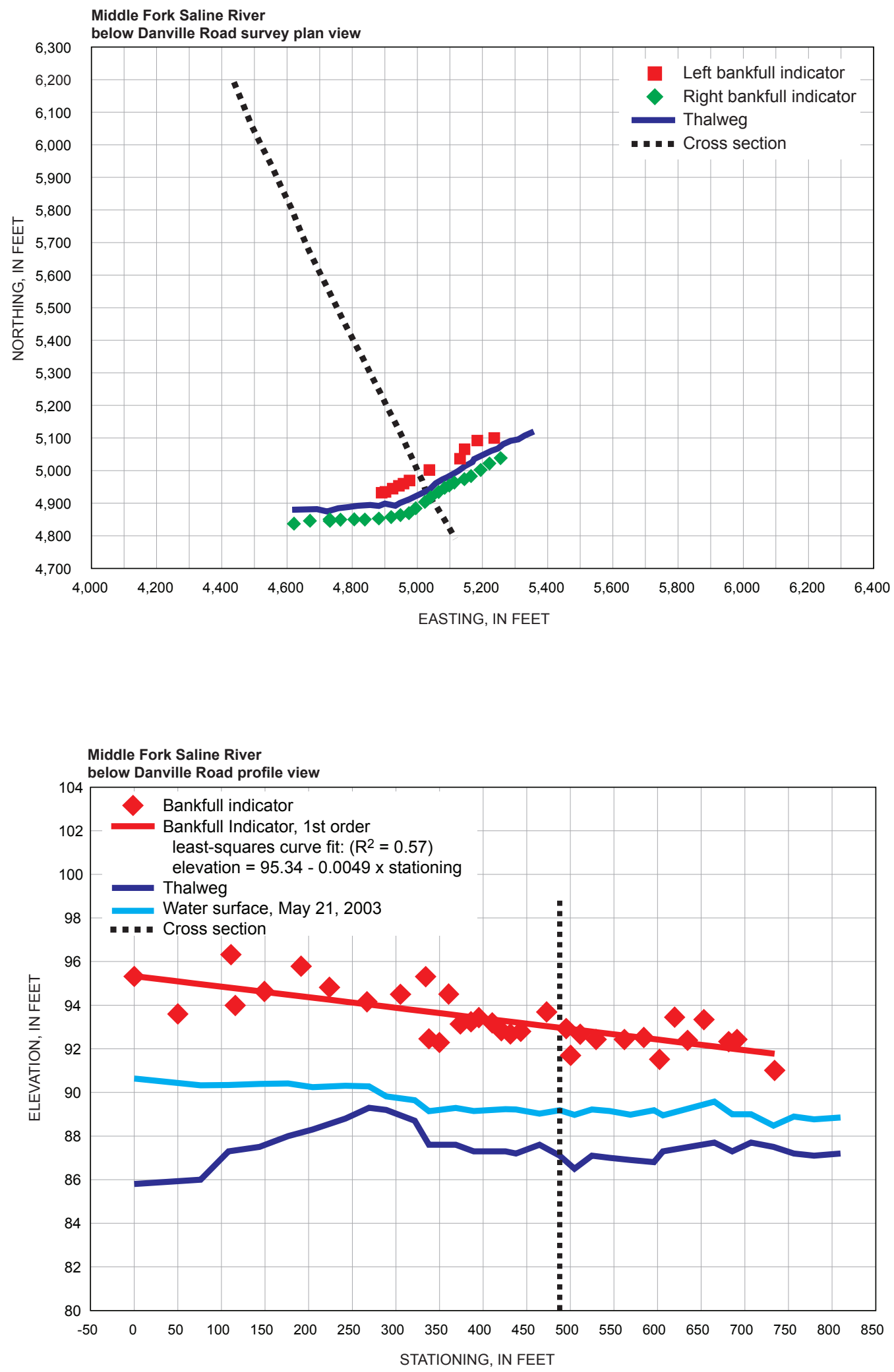


\title{
APPENDIX 8: Below Danville Road
}

\author{
Drainage Area: $71.0 \mathrm{mi}^{2}$ \\ (uncontrolled area is $61.9 \mathrm{mi}^{2}$ )
}

\section{SITE SURVEY DATA PLOTS}
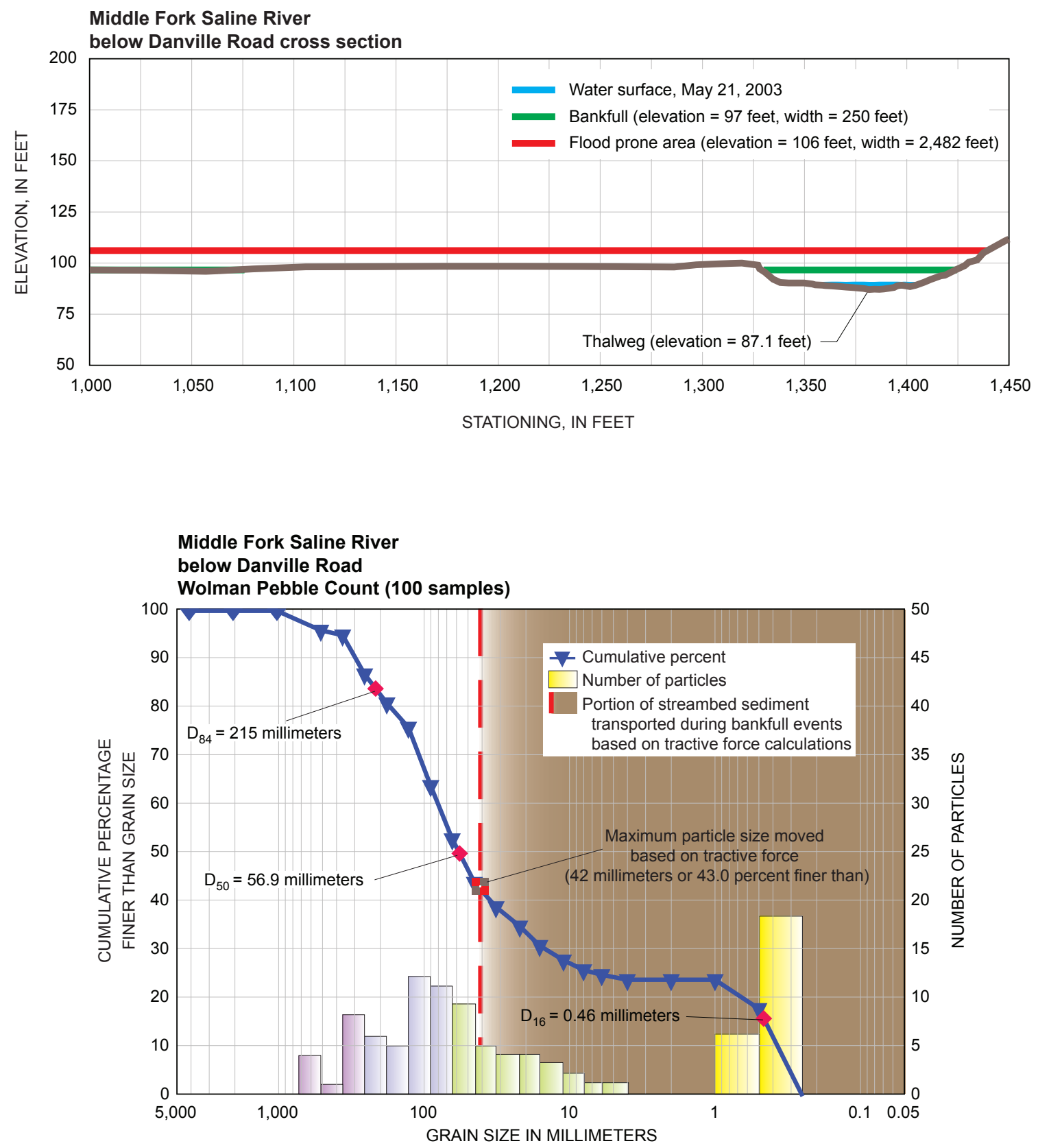

Percent (\%) by particle type based on total count (100):

\begin{tabular}{c|c|c|c|c|l}
\hline Bed- & Boulder & Cobble & Gravel & Sand & Silt or \\
rock & $13 \%$ & $34 \%$ & $29 \%$ & $24 \%$ & Clay \\
\hline
\end{tabular}


APPENDIX 8: Below Danville Road

\section{SITE SURVEY DATA PLOTS}

Middle Fork Saline River below Danville Road, May 22, 2003
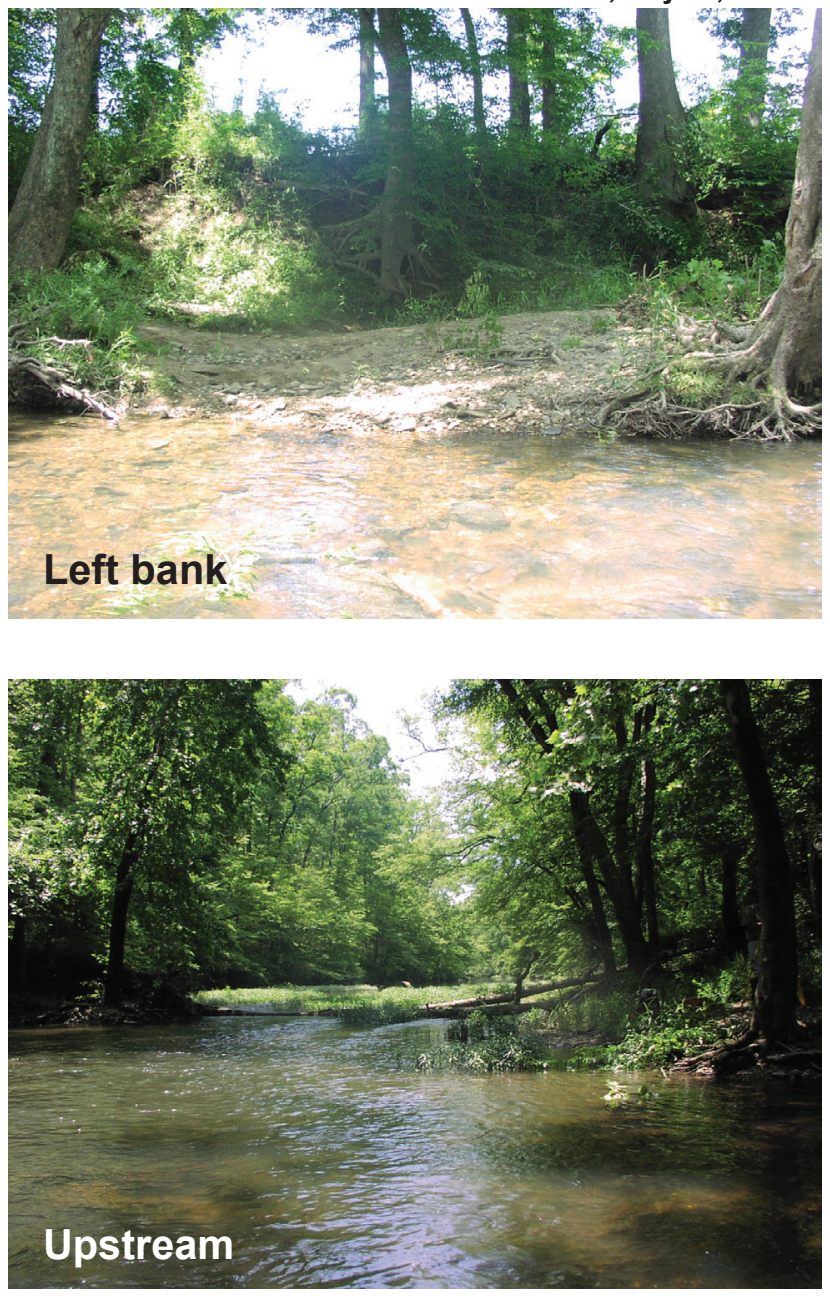

Drainage Area: $71.0 \mathrm{mi}^{2}$ (uncontrolled area is $61.9 \mathrm{mi}^{2}$ )
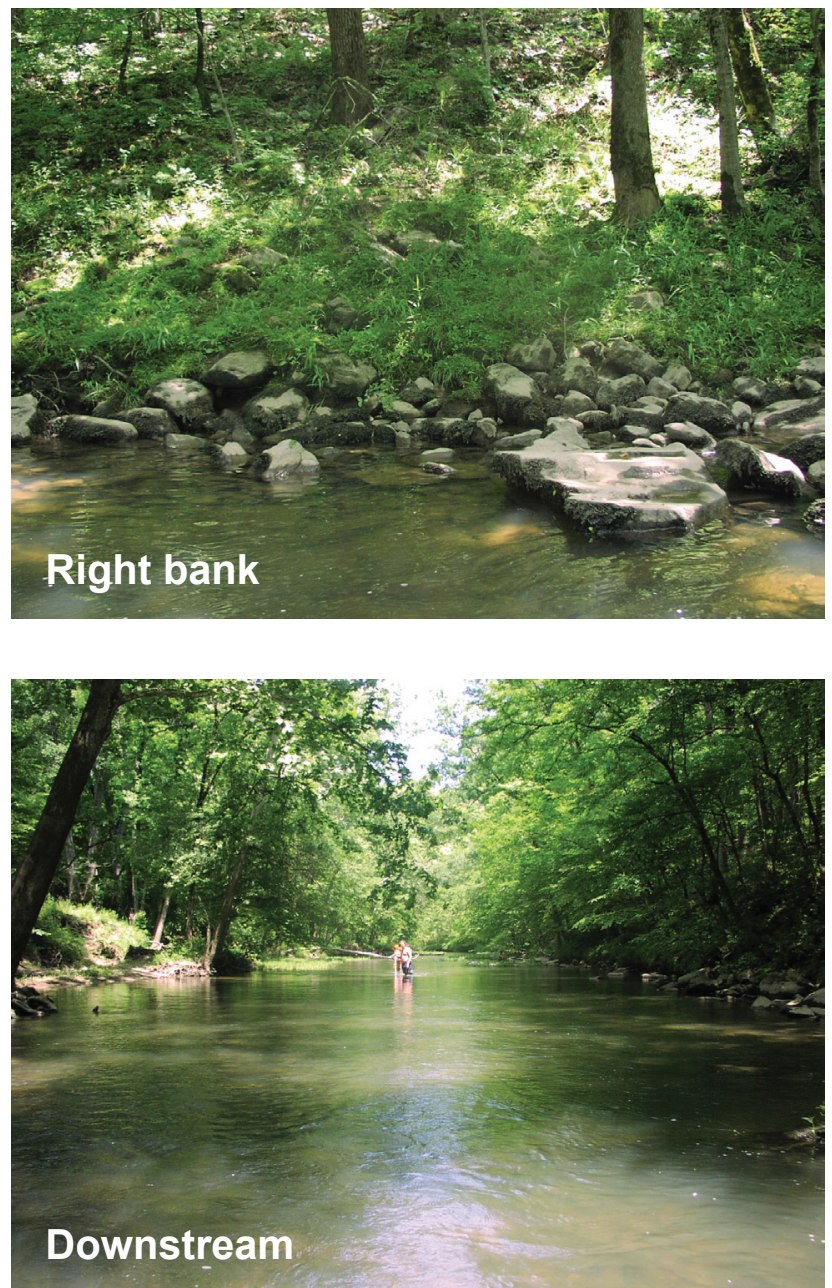


\section{APPENDIX 9: Vance Road}

\section{LOCATION}

Reach: Middle Fork above Vance Road Bridge

County: Saline

Quadrangle map: Lonsdale NE

\section{BANKFULL CHARACTERISTICS}

Stage: $10.3 \mathrm{ft}$ above thalweg

Cross-sectional area: $997.8 \mathrm{ft}^{2}$

Top width: $248.3 \mathrm{ft}$

Mean depth: $4.0 \mathrm{ft}$

Hydraulic radius: $3.4 \mathrm{ft}$

\section{STREAM CLASSIFICATION}

Flood prone width: $>800 \mathrm{ft}$

Entrenchment ratio: 3.2

Stream type: $\mathrm{C}_{/ 1}$

\section{Drainage Area: $90.8 \mathrm{mi}^{2}$ (uncontrolled area is $81.7 \mathrm{mi}^{2}$ )}

Section: SW 1/4 SW 1/4 Sect. 3

Township: 1 South

Range: 17 West

Slope: $0.0028 \mathrm{ft} / \mathrm{ft}$

Tractive force: $0.67 \mathrm{lbf} / \mathrm{ft}^{2}$

Particle size transported: $34 \mathrm{~mm}$

Portion of bed material transported: 44.8 percent

\section{LOCATION AERIAL PHOTOGRAPH - MAP}

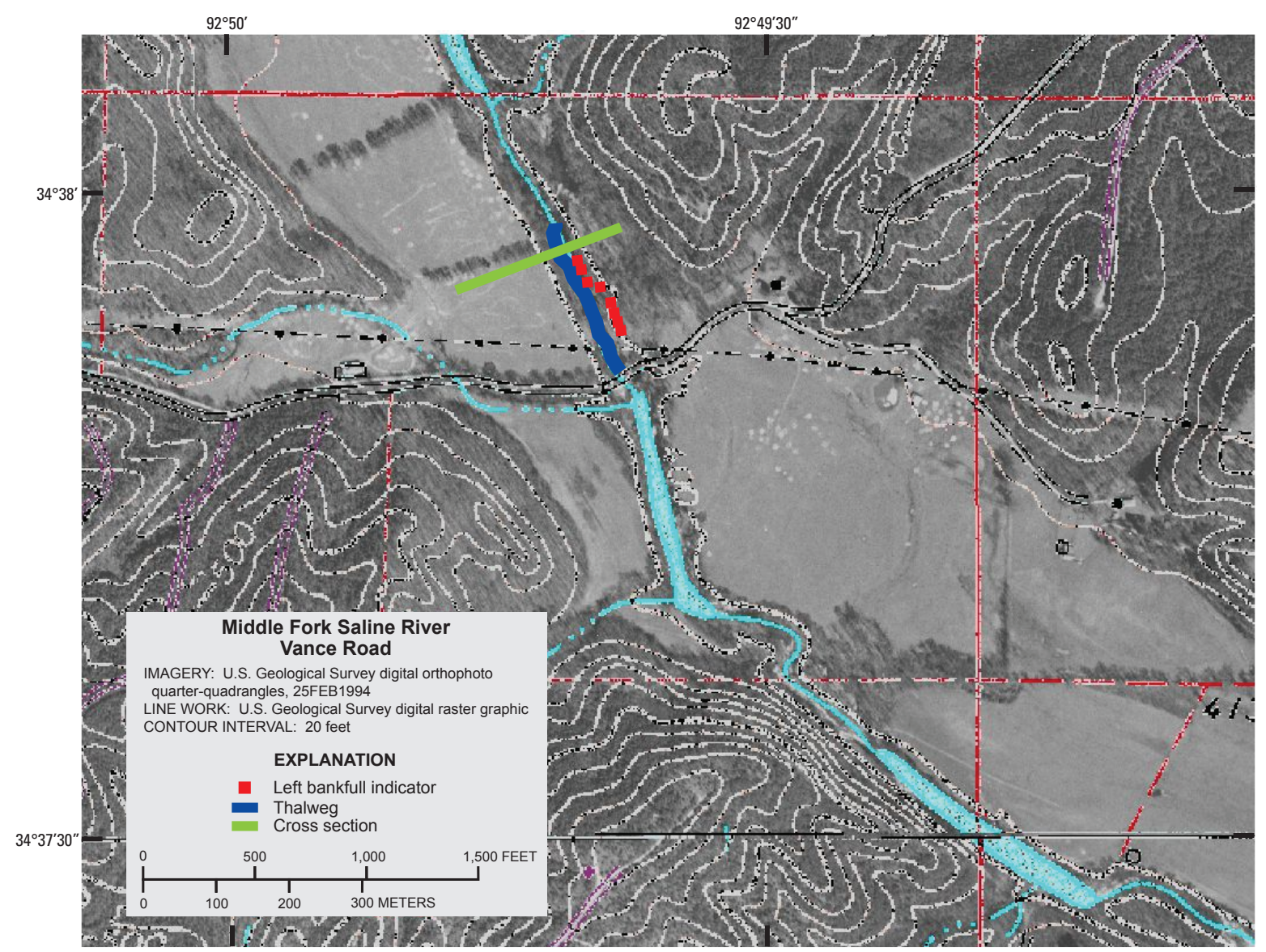


APPENDIX 9: Vance Road

\section{Drainage Area: $90.8 \mathrm{mi}^{2}$ (uncontrolled area is $81.7 \mathrm{mi}^{2}$ )}

\section{SITE SURVEY DATA PLOTS}
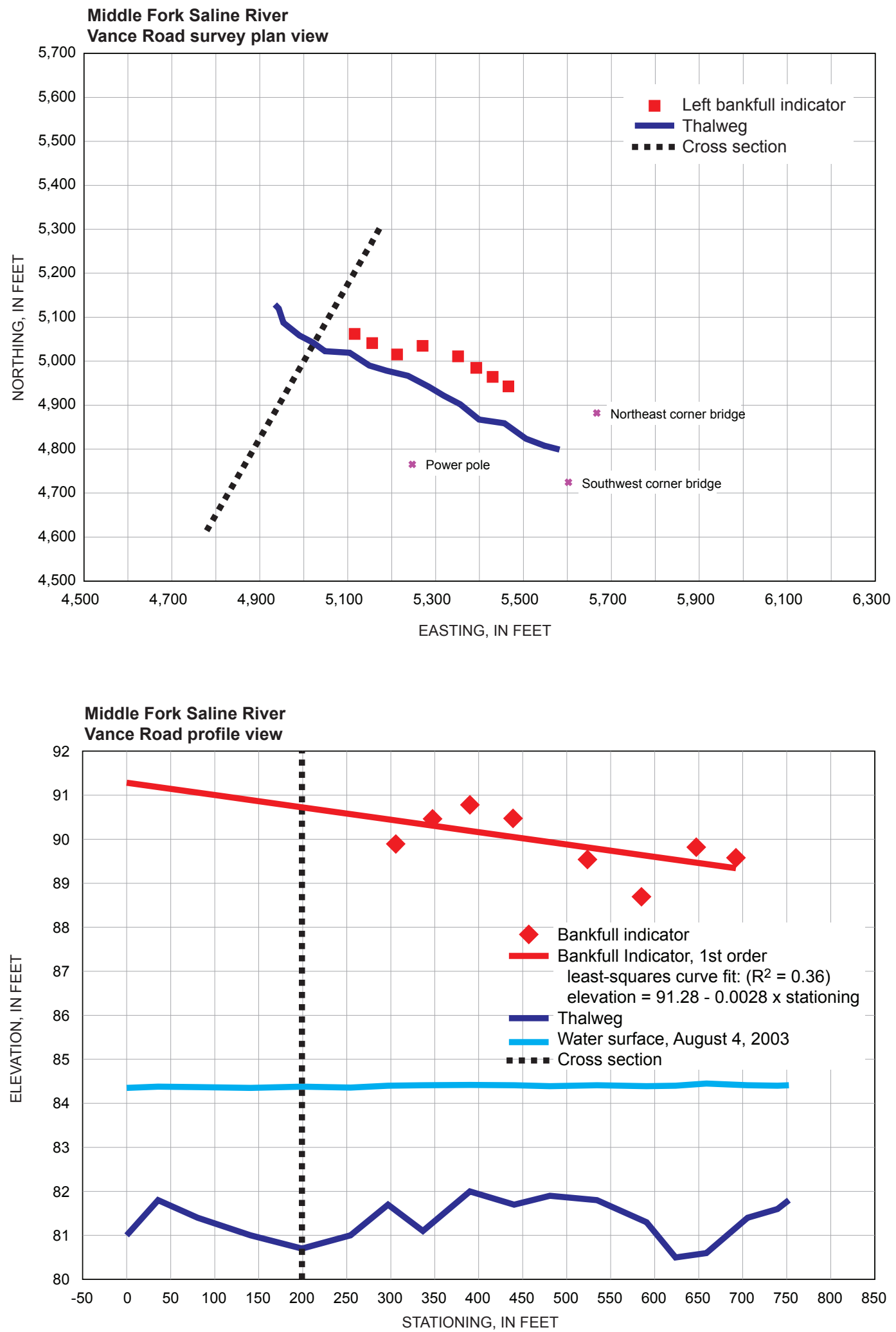


\section{APPENDIX 9: Vance Road}

\section{Drainage Area: $90.8 \mathrm{mi}^{2}$ (uncontrolled area is $81.7 \mathrm{mi}^{2}$ )}

\section{LOCATION}
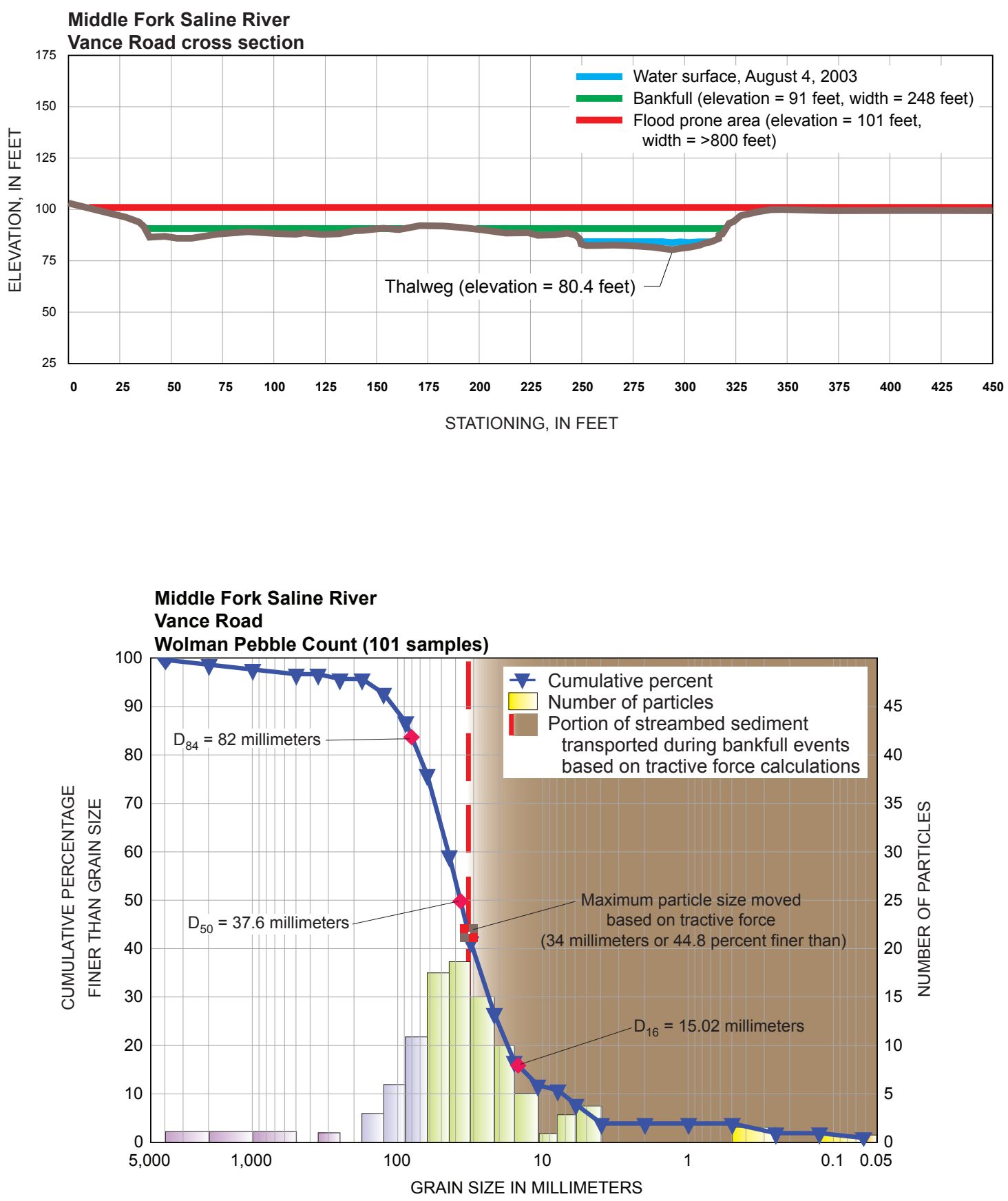

Percent (\%) by particle type based on total count (101):

\begin{tabular}{c|c|c|c|c|c}
\hline Bed- & Boulder & Cobble & Gravel & Sand & Silt or Clay \\
rock & $4 \%$ & $20 \%$ & $72 \%$ & $3 \%$ & $1 \%$ \\
\hline
\end{tabular}




\section{APPENDIX 9: Vance Road}

\section{LOCATION}

Middle Fork Saline River

Vance Road, August 4, 2003
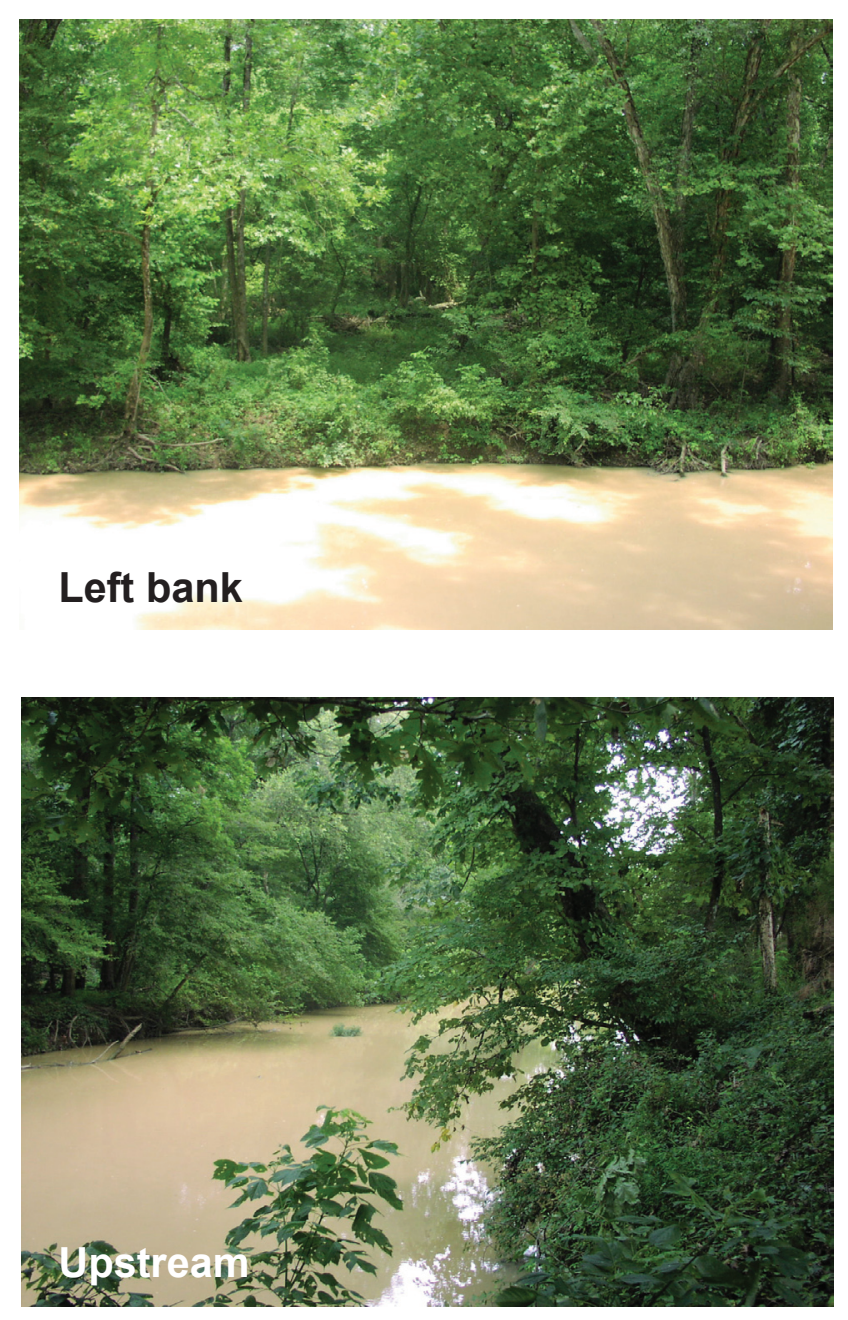

\section{Drainage Area: $90.8 \mathrm{mi}^{2}$ (uncontrolled area is $81.7 \mathrm{mi}^{2}$ )}


Publishing support provided by:

Lafayette and Rolla Publishing Service Centers

For more information concerning the research described in the report:

U.S. Geological Survey

Arkansas Water Science Center

401 Hardin Road

Little Rock, AR 72211-3528

(501) 228-3600

http://ar.water.usgs.gov 
